\title{
Mobilidade e interconexões oceânicas: o engenheiro militar e o artífice entre a Capitania do Ceará e o reino de Portugal
}

Displacement and ocean interconnections: military engineer and journeyman between the Captaincy of Ceará (Brazil) and the kingdom of Portugal

https://doi.org/10.1590/1982-02672021v29d le16

\section{CLOVIS RAMIRO JUCÁ NETO'}

https://orcid.org/0000-0002-8424-1527

Universidade Federal do Ceará / Fortaleza, CE, Brasil

\section{JOSÉ RAMIRO TELES BESERRA²}

https:/ / orcid.org/0000-0001-7861-7842

Universidade Federal do Ceará / Fortaleza, CE, Brasil

RESUMO: Este artigo pressupõe a Capitania do Ceará conectada a um Império em movimento. Analisa o deslocamento, as ações e as intervenções idealizadas e executadas por engenheiros militares e artífices em trânsito entre as Capitanias do Norte do Brasil e parte do Reino. Neste passo, contribui para decolonizar a historiografia tradicional e romper com a ideia de isolamento cultural e econômico da capitania. Diante do mundo português interconectado, o deslocamento e a ação dos profissionais é caminho possível de análise não insular do processo de colonização do território cearense. Importa pensar suas trajetórias de vida: movimentando-se entre os mais distantes lugares do Reino, conectando longínquos mundos em rotas transoceânicas e percursos territoriais, iluminam o sentido global do empreendimento colonizador, difundindo e apreendendo saberes, intervindo no espaço territorial e urbano. Este estudo considera tanto o conhecimento técnico-científico e empírico dos engenheiros e artífices como a transferência, a absorção e as rupturas de técnicas, formas e ideias expressas em idealizações e intervenções híbridas.

\begin{abstract}
1. Professor associado de Arquitetura no Departamento de Arquitetura e Urbanismo e Design da Universidade Federal do Ceará (UFC). Professor do Programa de Pós-Graduação em Arquitetura e Urbanismo e do Programa de Pós-Graduação em História na UFC. Cursa pós-doutorado no Centro de Humanidades da Faculdade de Ciências Sociais e Humanas da Universidade Nova de Lisboa.E-mail: <clovisj@ uol.com.br>.
\end{abstract}

2. Doutorando no Programa de Pós-Graduação em Arquitetura e Urbanismo da Universidade de São Paulo (USP). Mestre em Arquitetura e Urbanismo e Design pela Universidade Federal do Ceará (UFC). Graduado em Arquitetura e Urbanismo pela mesma instituição, com período sanduíche na Escuela Técnica Superior de Arquitectura da Universidad de Valladolid (Espanha). E-mail: $<$ ramiroteles@gmail.com>. 
PALAVRAS-CHAVE: Engenheiro militar. Artífice. Ceará-Portugal. Arte-arquitetura. Século XVIII.

ABSTRACT: This article assumes the Captaincy of Ceará (Brazill) connected to an empire in movement. It analyzes the displacement, actions and interventions devised and executed by military engineers and journeymen in transit between the Northern Captaincies and part of the Kingdom. In this sense, it contributes to decolonize the traditional historiography and change the idea of cultural and economic isolation of the captaincy. In the face of the interconnected Portuguese world, the displacement and action of professionals is a possible way of non-island analysis of the conquest and fixation in Ceará's territory. It is important to think about life trajectories. By moving among the most distant places in the Kingdom, connecting distant worlds on transoceanic and territorial routes, they illuminate the global meaning of the colonizing undertaking, spreading and apprehending knowledge, intervening in the territorial and urban space. This study considers both the technicalscientific and empirical knowledge of engineers and journeymen and the transfer, absorption, ruptures of techniques, forms and ideas, expressed in idealizations and hybrid interventions.

KEYWORDS: Military engineer. Journeyman. Ceará-Portugal. Art-architecture. $18^{\text {th }}$ century. 
A historiografia tradicional brasileira entende a Capitania do Ceará como região insulada. No entanto, recentes estudos rompem com tal perspectiva arquipelágica; ${ }^{3}$ amplificam a inserção do território cearense nas dinâmicas do Império Português, por meio de interconexões globais e regionais; manifestam sínteses entre dispositivos colonizadores e condicionantes físico-sociais próprios dos lugares de fixação; colocam à mostra padrões de colonização flexíveis e adaptáveis às oportunidades, ${ }^{4}$ pautados em inflûencias diversas, mesclados no contato com lugares e culturas distantes, matizado com formas variadas, orbívagas e em permanente transmutação.

Este artigo pressupõe a Capitania do Ceará não insulada, conectada ao Império em movimento, e analisa o deslocamento e as intervenções idealizadas e executadas por engenheiros militares e artífices. Tal reflexão contribui para decolonizar a historiografia tradicional e romper com a ideia de isolamento cultural e econômico desse território.

Diante do mundo português interconectado, pensar o trânsito e a ação desses homens é caminho possível de análise não insular do processo de colonização da capitania cearense. Este estudo considera o conhecimento técnicocientífico e empírico dos engenheiros e artífices, assim como a transferência, a absorção e as rupturas de técnicas, formas e ideias entre a Capitania do Ceará e - Reino. A apreciação investiga as idealizações dos profissionais e as resultantes, locais e híbridas, da relação arte-arquitetura. Se a presença e a ação desses homens confirmam o movimento de técnicas, ideias e formas conectando a Capitania do Ceará às demais Capitanias do Norte e ao restante do Reino, e vice-versa, a análise das intervenções idealizadas e realizadas não deve desconsiderar os condicionantes físicos e sociais da conquista e fixação no território.
3. Dentre os estudos, destacamos Matrizes e capelas do Ceará: circularidade e conexões atlânticas: arquitetura e artífices entre os sertões do Norte e Portugal (1700-1820), de José Ramiro Teles Beserra (2018); Um sertão entre tantos outros: fazendas de gado nas Ribeiras do Norte, de Nathália Diniz (2013); Ecos de um suposto silêncio: paisagem e urbanização dos "certoens" do Norte, $c$. 1666-1820, de Damião Esdras Araujo Arraes (2017); A rosa dos ventos dos sertões do Norte: dinâmicas do território e exploração colonial (c. $1660-c$. 1810), de Leonardo Cândido Rolim (2019); A Capitania do Siará Grande nas dinâmicas do Império Português: politica sesmarial, guerra justa e formação de uma elite conquistadora (1679-1720), de Rafael Ricarte da Silva (2016); Viver à lei da nobreza: elites locais e o processo de nobilitação na Capitania do Siará Grande (1748-1804), de Gabriel Parente Nogueira (2017); e Novos ares, nova vida: mobilidade, casamento e família nos sertões do Siará Grande (17591766), de Adson Rodrigo Silva Pinheiro (2016).

4. Cf. Russell-Wood (2020).

\section{O REINO DE PORTUGAL EM MOVIMENTO}

Com Russell-Wood em O Império Português, 14 15-1808: o mundo em movimento, destacamos a "natureza global" do empreendimento português. $\bigcirc$ historiador reforça a "noção de interconectividade não só entre os componentes marítimos e terrestres, como também entre as diferentes esferas da atividade", contrabalançando a "propensão de especialistas em compartimentarem o 
5. Id. (2017, p. 15).

6. Ibid., loc. cit.

7. Ibid., loc. cit.

8. Ibid., p. 17.

9. Ibid., p. 10.

10. Moreira (2011, p. 13).
Império em regiões geográficas distintas" ou "em imporem, por vezes, limitações cronológicas artificiais". ${ }^{5}$

A despeito do muito que pode ser apreendido em pesquisa com abordagem localizada - do português no Brasil, na Índia, na África etc. -, para Russell-Wood, a análise insulada, restrita a um único continente, perde a "noção do todo", correndo-se o risco de uma "apreciação diminuída do âmbito global e da interconectividade do empreendimento imperial". O autor considera o processo colonizador "multioceânico" e "multicontinental", ocorrendo em "simultâneo, não em série". Uma visada analítica insulada incorre no risco de uma compreensão parcial da dinâmica imperial. ${ }^{6}$

Quanto às periodizações, em Russell-Wood, os "feitos, fracassos e êxitos devem ser vistos na longue durée". Nas dinâmicas do Império, "acontecimentos discretos e encontros únicos devem ser contextualizados não só dentro do período imediato em que ocorreram", mas também numa "cronologia mais ampla". Enfim, "tal fragmentação, seja ela geográfica ou cronológica, prejudica a natureza universal dos feitos lusos".?

Os portugueses foram, para Russell-Wood, "não só os primeiros europeus a estabelecerem, do ponto de vista europeu, as fronteiras do mundo moderno", como também foram os primeiros, "num grau nunca igualado por outra nação europeia nos primórdios do período moderno, a entrarem em contato, a iniciarem trocas e a manterem relações com pessoas" de uma larga diversidade de "origens raciais, culturais, religiosas e nacionais". ${ }^{8} \bigcirc$ contato entre os mais diversos povos, europeus e não europeus, anunciou "uma nova era de globalização transcontinental, transoceânica e transnacional, que seria caracterizada por interdependência, interação e intercâmbio". 9

Em sintonia com o pensamento de Russell-Wood, para Rafael Moreira o Brasil foi, "durante mais de trezentos anos, área de uma entidade mais geral, abrangendo mais da metade do globo, da América do Sul ao Extremo Oriente, passando por quase toda a África, em torno dos 'mundos' do oceano Atlântico e do Índico"; ou seja, "uma parte de um único país, fortemente centralizado e em contínua circulação, com seu epicentro na Corte lusa". ${ }^{10}$ Para o autor, Portugal foi o "primeiro império planetário que abriu o caminho aos que vieram muito depois: o 'pioneiro da globalização'". Em A circulação das formas: artes portáteis, arquitectura e urbanismo, Rafael Moreira reflete sobre o caráter não insular da ação portuguesa trabalhando a presença "lusa em muitas das zonas do Índico e do mar da China". Indício da circularidade de formas no mundo global lusitano são os reflexos da "originalidade bem vincada e inconfundível" do "universo visual 
indo-português [...] na cultura artística tanto do Brasil, África e ilhas atlânticas [...] quanto da própria metrópole". " A reflexão de Russell-Wood e Rafael Moreira faz vibrar o sentido de um Reino interconectado, transoceânico, não insular.

\section{O CEARÁ NA ROTA DAS MIGRAÇÕES}

arquiteto José Liberal de Castro, em mais uma síntese certeira sobre a colonização do Ceará, assevera que "condições históricas-geográficas especiais condicionaram a ocupação demográfica do solo cearense - tardia e pobre, ampla e rarefeita". ${ }^{12}$

"Até a expulsão dos holandeses em 1654", a ocupação do território cearense se "restringia ao litoral, mais especificamente [...] onde hoje se encontra o Forte de Nossa Senhora da Assumpção, em Fortaleza". ${ }^{13}$ Somente nos últimos anos do século XVII, a atividade pecuária, expulsa do litoral açucareiro, adentrou os sertões das Capitanias do Norte em direção ao Piauí e ao Maranhão em busca por novas pastagens. ${ }^{14}$ Alcançando o Ceará, a atividade criatória atribuiu sentido econômico ao processo de colonização do territorio durante o século XVIII. ${ }^{15}$ Toda a conquista e instalação dos vaqueiros fora extremamente complexa e violenta, marcada por "campanhas belicosas sistemáticas de expulsão, extinção ou aculturação dos índios". 16 No fim da primeira metade do Setecentos, os produtos derivados da pecuária eram transportados para os mercados consumidores na costa oriental do Nordeste tanto por meio da remessa do gado em pé, cruzando os sertões, quanto já abatidos e salgados no litoral da capitania - a "carne do Ceará" - e enviados por via marítima para os pontos de consumo.

Os desbravadores e suas boiadas seguiram antigos caminhos indígenas, que por sua vez trilharam os percursos naturais dos sertões, invariavelmente acompanhando o leito de rios e riachos. Cada rio ou riacho possuía sua estrada da ribeira. As principais rotas, denominadas por Studart Filho como "estradas das boiadas", conectaram pontos longínquos da capitania. ${ }^{17}$ Por todo o século XVIII, os desbravadores construíram suas casas de fazenda e levaram suas famílias ${ }^{18}$ e, em pontos estratégicos do território - no cruzamento dos caminhos, na foz do Rio Jaguaribe, no sopé ou no alto de alguma serra e nas proximidades do Forte de Nossa Senhora da Assumpção -, o Estado português fundou vilas. ${ }^{19}$ Também em lugares estrategicamente situados, a lgreja estabeleceu aldeamentos, missões e freguesias com suas igrejas matrizes e capelas. ${ }^{20}$
11. Id. (1998, p. 533-534).

12. Castro (2012a, p. 17).

13. Jucá Neto (2012b, p. 157).

14. Uma série documentos reais demarcaram limites para a atividade do criatório a partir da área de plantio da cana (Ibid., p. 236-237).

15. Nos aproximamos do entendimento de Moraes (2000, p. 276-278, grifos do autor) sobre as "etapas do processo de colonização, isto é, dos momentos diferenciados vividos pelos processos colonizadores". O primeiro "refere-se à própria descoberta (ou 'achamento') e exploração das novas terras". O segundo, "à conquista propriamente dita, tendo como resultado a instalação dos colonizadores nos novos sítios. Trata-se de uma etapa inicial de submissão das populações locais e de apropriação dos lugares, envolvendo a pioneira edificação dos assentamentos europeus na América" - em nosso caso, no Ceará. O terceiro, à "consolidação" do domínio territorial. O quarto, à "fase de complexização das estruturas de colonização já consolidadas, envolvendo o estabelecimento de atividades complementares com certa especialização regional no interior das colônias". Tem-se a "estruturação de circuitos internos que articulam espaços dilatados, em que se observa uma divisão territorial da produção, e uma hierarquização dos fluxos e dos assentamentos".

16. Castro (2012a, p. 17). Cf. também Putoni (2002) e Jucá Neto (2012b).

17. Studart Filho (1937, p. 39). 18. Cf. Jucá Neto (2019).

19. Id. (2012).

20. Id. (2012a, 2012b, 2014, 2019); Jucá Neto, Andrade e Ponte (2014). 
21. Ibid.

22. Sobre as fazendas do Ceará nos século XVIII e XIX, ver Jucá Neto (2019).

23. Castro (2012a, p. 17).

24. Arruda (2013, p. 15).

25. De acordo com Russell-Wood (2020, p. 186), fatores de "incentivo e atracção" levavam os portugueses a migrar para outras regiões do Reino. Os fatores de incentivo foram "a lei do morgadio, a qualidade e a extensão inadequadas das terras para garantir o sustento, as dificuldades físicas, o serviço militar forçado, a insatisfação com as condições prevalecentes "financeiras, domésticas, religiosas ou políticas, a fome, as epidemias e a desordem causadas pelas guerras". Já os fatores de atração foram a "terra gratuita, a existência de oportunidades e a perspectiva de ascensão financeira e social".

26. Cf. Gutiérrez (1989).
No Setecentos, a instalação foi pautada por baixo investimento de técnica e capital por parte da Coroa. $\bigcirc$ pouco interesse econômico e geopolítico português decorria, em primeira instância, da pouca rentabilidade do criatório, a despeito de a economia ser responsável pela formação de um mercado interno na colônia. Também a capitania cearense não era prioritária na geopolítica de ocupação e expansão dos limites territoriais da América portuguesa. Por fim, desde a expulsão dos holandeses da costa do Ceará, em 1654, a capitania não foi alvo de invasões estrangeiras. ${ }^{21}$

Ainda assim, no lastro do criatório, a teia de caminhos esboçada nos primórdios do século XVIII consolidou-se ao longo da centúria, fortalecendo uma capilarizada rede de freguesias, vilas e povoados, pontuadas por capelas, igrejas, fazendas ${ }^{22}$ e pousos, possibilitando fluxo de mercadorias, homens e ideias, e interligando a capitania aos mais distantes lugares do atual Nordeste, às demais regiões do Brasil e a outras partes do Reino. Castro assevera que a atividade pecuária cobriu todo o Ceará, "de tal maneira que, no final do século XVIII, nenhum dos ínvios e mais escondidos rincões da capitania se mostrava desconhecido da população". 23

Durante o Setecentos, colonos oriundos de outras regiões do Brasil e de Portugal migraram para o Ceará e, intercruzando a rede de caminhos, fortaleceram, em trânsito, conexões territoriais. Muitas vezes se estabeleceram no território cearense, fixando-se nos mais recônditos lugares dos sertões. Como assevera José Arruda, isso foi preciso "para constituir o exército de trabalhadores indispensáveis à produção da riqueza necessária para alimentar a própria máquina de dominação". ${ }^{24}$

Evidências da cultura material, enquanto síntese da conquista, confirmam intensa circulação de homens e vocabulário plástico entre o Ceará, as Capitanias do Norte e o Reino. Revisar historicamente a Capitania do Ceará, (re) posicionando-a nas dinâmicas do Império, tem como caminho possível conhecer as modalidades e origens de tais fluxos migratórios que contribuíram para sua ocupação e para o delineamento de seu território.

A implementação e sedimentação de uma cultura arquitetônica-artística no Ceará colonial deve ser entendida considerando-se a dinâmica existente entre o meio físico (os sertões e os litorais), o contexto social (agentes da produção arquitetônica em circulação pelo Reino) e os condicionantes econômicos. Essa dinâmica foi, em parte, viabilizada pelo vertiginoso processo migratório ${ }^{25}$ direcionado para as Capitanias do Norte a partir de fins do século XVII. No curso das migrações, o fluxo de homens, ideias e técnicas, em contato com condicionantes físico-sociais locais, resultou em materialidades processadas em contínuo movimento de transculturação. ${ }^{26}$ 
Segundo Joel Serrão, integrando as diretrizes reais de administração e de povoamento, os movimentos migratórios processaram-se a partir de duas valências: a do colonizador e a do emigrante. $\bigcirc$ colonizador deixa sua pátria por motivação pessoal, de livre vontade, geralmente com vistas a galgar melhor situação financeira com a expectativa de oportunidades na florescente colônia. Já o emigrante estaria estreitamente ligado à máquina administrativa colonial, desempenhando funções públicas e sem interesse de fixação definitiva no Brasil, regressando posteriormente a Portugal. ${ }^{27}$

Integrando esse contingente emigrado, no que importa a este estudo, estavam de um lado os engenheiros militares, emigrantes, funcionários da Coroa que percorriam longas distâncias entre as possessões portuguesas, a desempenhar as especificidades de seu ofício como função administrativa, demorando-se pouco tempo aqui e alhures, no mais das vezes retornando à metrópole; e, de outro, toda uma "plêiade de oficiais mecânicos", ${ }^{28}$ dentre eles artífices construtores, colonos que se fixavam no Brasil, valendo-se de seu ofício como forma de obter melhores condições de vida.

Com o considerável afluxo de gentes rumo aos sertões do Norte, a Coroa interveio jurisdicionando e controlando a ocupação desse novo território. Durante todo o Setecentos, vilas e freguesias foram fundadas nos sertões cearenses como parte do movimento de expansão em direção à América espanhola. Tais estruturas da implementação do projeto colonial29 de conquista do sertão constituíram polos de atração da mão de obra especializada, seja de engenheiros, seja de oficiais mecânicos - entalhadores, pintores, pedreiros, carpinas, ferreiros, entre outros.

Esses profissionais foram os principais agentes da prática construtiva e da circularidade arquitetônica e de formas do Ceará colonial. Agiram num raio espantosamente dilatado, mantendo redes de relações econômicas, profissionais e afetivas que alinhavavam conexões entre Portugal - perpassando longínquos pontos do Império ultramar português na Ásia - e múltiplas regiões do Brasil. Interessa-nos analisar o movimento desses agentes rumo ao litoral e aos sertões da capitania, de onde vieram, por onde circularam e onde se fixaram, transfundindo sua carga cultural reinol e imagético-arquitetônica às gentes da terra e a outros povos que para o Ceará já haviam refluído, constituindo um prolífico ambiente de "fertilização mútua", 30 que deixaria indeléveis rugosidades na organização do espaço territorial e urbano cearense.

No caso da Capitania do Ceará, verificou-se que grande parte do aporte migratório afluiu especialmente da região Norte de Portugal, do Entre-Douro-eMinho, provavelmente pelas facilidades de navegação naquela região. A título de amostragem, contabilizou-se o número de batizados da Freguesia do lcó, uma
27. Serrão (1970, p. 598).

28. Bueno (2012, p. 336).

29. Ver as estruturas da colonização em Russell-Wood (2020).

30. Burke (2003). 
31. Nesses registros, por determinação das Constituições da Igreja Católica, eram sempre mencionadas as naturalidades do pai e da mãe e, frequentemente, dos avós maternos e paternos.

32. Livro ${ }^{\circ} 4$ da Freguesia... (1763-1783).

33. Ibid.

34. Lima (2016, v. 1, p. 9). das mais populosas no Ceará, entre os anos de 1763 e 1783. Da totalidade de 932 assentamentos verificados, tem-se que, em $75 \%$ dos registros, as partes ${ }^{31}$ eram de origem migrante, e apenas $25 \%$ registravam naturalidade cearense, conforme se depreende do mapa (Figura 1).

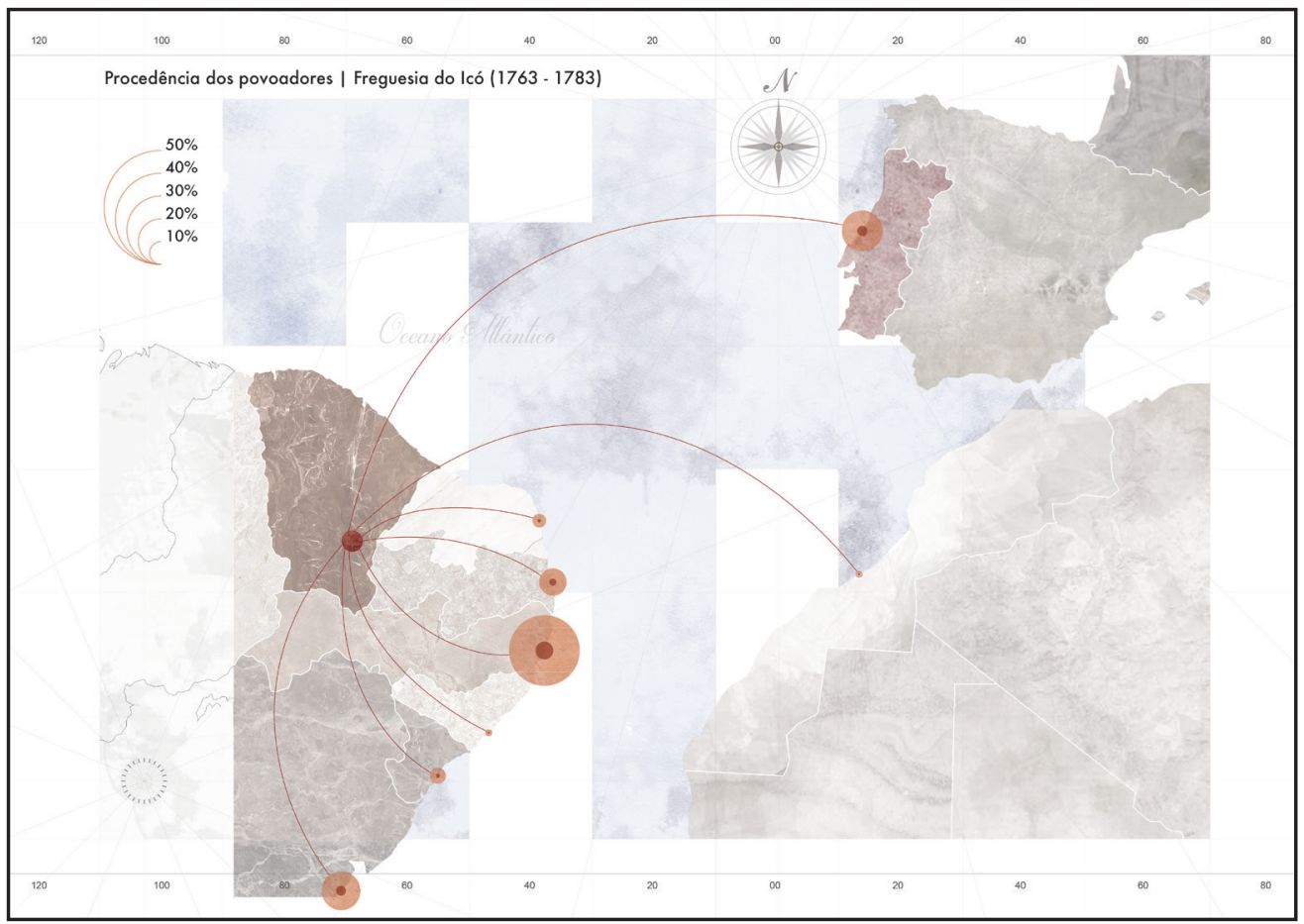

Figura 1 - Procedência dos povoadores da Freguesia do Icó (1763-1783). Fonte: Cartografia retrospectiva elaborada pelos autores a partir de registros do Livro $n^{\circ} 4$ da Freguesia de Nossa Senhora da Expectação de Icó - Batizados (1763-1783). ${ }^{32}$

Das 707 ocorrências de migrantes, $31 \%$ eram pernambucanos, seguidos por portugueses, que ascendiam a $18 \%$. Sucedem-se paraibanos (12\%), baianos (10\%), sergipanos $(7 \%)$, potiguares $(6 \%)$ e alagoanos $(3 \%)$. Havia ainda a procedência genérica "natural do Rio de São Francisco", obviamente dos sertões baianos, sem especificação da naturalidade. Estes contabilizaram 7\%. Indígenas participavam com $3 \%$, e africanos também com $3 \% .{ }^{33}$ Os números não se distanciam dos quantitativos obtidos em estudos genealógicos realizados por Francisco Araújo Lima, abrangendo todo o território cearense, durante o século XVIII, tomados de registros paroquiais coevos, ${ }^{34}$ em que figuram Portugal, Pernambuco e Bahia como maiores centros dispersores de colonos para o Ceará (Tabela 1). 
Tabela 1 - Tabela comparativa da origem dos povoadores entre o Ceará e a Freguesia do Icó

\begin{tabular}{|l|c|c|}
\hline Origem & Ceará (1) & Icó (2) \\
\hline Portugal & $12,96 \%$ & $18,00 \%$ \\
\hline Pernambuco & $32,23 \%$ & $31,00 \%$ \\
\hline Paraíba & $19,81 \%$ & $12,00 \%$ \\
\hline Bahia & $14,11 \%$ & $17,00 \%$ \\
\hline Rio Gde. Norte & $8,43 \%$ & $6,00 \%$ \\
\hline Alagoas & $5,15 \%$ & $3,00 \%$ \\
\hline Sergipe & $4,97 \%$ & $7,00 \%$ \\
\hline Índios & - & $3,00 \%$ \\
\hline Escravos & - & $3,00 \%$ \\
\hline Total & $100,00 \%$ & $100,00 \%$ \\
\hline
\end{tabular}

Fonte: Elaborada por Ramiro Teles a partir de (1) Lima ${ }^{35}$ e do (2) Livro $n^{\circ} 4$ da Freguesia de Nossa Senhora da Expectação de Icó - Batizados (1763-1783). ${ }^{36}$

A documentação revela um dado negligenciado pela historiografia cearense: a massiva migração portuguesa para os sertões do Ceará, no Setecentos, e a evidente influência desse contingente emigrado na sua cultura material, com rebatimentos na produção arquitetônica. A terça parte dos emigrados em Icó era de origem portuguesa e, dessa parcela, conforme se depreende da análise dos lugares registrados, mais de $86 \%$ eram naturais do norte português.

O mesmo padrão migratório já foi apontado pela historiografia tradicional brasileira como elemento-chave para interpretar as origens plásticas e atribuir valor excepcional às celebradas obras arquitetônicas das Minas Gerais. A despeito desses estudos, os dados apontam que outras regiões e arquiteturas do país também foram plasmadas pelo mesmo contributo social. ${ }^{37}$ Ao decompor o percentual de colonos portugueses de Icó - 18\%, correspondentes a 131 indivíduos -, percebe-se que a maior cota de colonos adveio justamente do Centro-Norte de Portugal, especialmente dos Arcebispados de Porto e Braga e suas freguesias anexas. Em seguida vêm as Ithas dos Açores, e Lisboa em último lugar (Tabela 2). Nilza Braga afirma que, nesse processo, operavam com grande vigor as redes de relações sociais e familiares, em que muitos eram chamados e acolhidos por parentes reinóis já estabelecidos de antanho na colônia. ${ }^{38}$
35. Id. (2006).
36. Livro $\mathrm{n}^{\circ} 4$ da Fregue- sia..., op. cit.
37. Dangelo (2006).
38. Braga (2013, p. 98). 
Tabela 2 - Origem dos povoadores portugueses que afluíram à Freguesia do Icó

\begin{tabular}{|c|c|c|}
\hline Origem & Qtde. & Total \\
\hline Portugal & 17 & \multirow{35}{*}{131} \\
\hline Porto & 48 & \\
\hline Leiria & 2 & \\
\hline Barcelos & 1 & \\
\hline Ihas & 7 & \\
\hline Arcebispado de Braga & 10 & \\
\hline Freguesia de Belém de Lisboa & 1 & \\
\hline Iha de Santa Maria & 1 & \\
\hline Santa Eulália de Passos & 3 & \\
\hline Itha de S. Miguel da Freguesia de N. Sra. da Apresentação & 2 & \\
\hline Trás-os-Montes & 2 & \\
\hline Santo Cosme de Gondomar & 1 & \\
\hline São Miguel de Braga & 3 & \\
\hline São Salvador de Tabosa do Arc. de Braga & 1 & \\
\hline Freguesia de Santo Tirso & 1 & \\
\hline Freguesia de Santiago de Modelos & 1 & \\
\hline São Salvador da Lavra do Arc. do Porto & 1 & \\
\hline Itha de São Miguel da Freguesia de São Pedro do Bispado de Itha $3^{a}$ & 2 & \\
\hline Freguesia de São Salvador de Braga & 2 & \\
\hline Freguesia de São Nicolau do Patriarcado de Lisboa & 1 & \\
\hline Iha da Madeira & 1 & \\
\hline Vila de Viana do Arcebispado de Braga & 1 & \\
\hline Lisboa & 4 & \\
\hline Coimbra & 1 & \\
\hline Matozinhos & 2 & \\
\hline Vila de Chaves do Arcebispado de Braga & 1 & \\
\hline Freguesia de São Sebastião de Badim do Arc. de Braga & 1 & \\
\hline Iha do Pico dos Açores & 1 & \\
\hline Freguesia de Darque de Oliveira & 1 & \\
\hline Freguesia de São Julião das Águas Longas & 1 & \\
\hline Guimarães & 1 & \\
\hline Vila Nova de Gaya da Freguesia de Santa Marinha & 3 & \\
\hline Vila do Conde & 1 & \\
\hline Freguesia de Vilela do Arc. de Braga & 2 & \\
\hline Freguesia de Nossa Senhora da Estrela & 1 & \\
\hline
\end{tabular}




\begin{tabular}{|l|c|c|}
\hline Origem & Qtde. & Total \\
\hline Freguesia de São Tiago de Mouquim & 1 & \multirow{2}{*}{131} \\
\cline { 1 - 2 } Vila de Monte-Mor & 1 & \\
\hline
\end{tabular}

Fonte: Elaborada por Ramiro Teles a partir de registros do Livro $n^{\circ} 4$ da Freguesia de Nossa Senhora da Expectação de Icó - Batizados (1763-1783). ${ }^{39}$

Tal realidade vai de encontro às visões estagnantes acerca do Ceará durante o século XVIII, que costumam vinculá-lo a uma imagem de isolamento. Pelo contrário, o estudo dos registros paroquiais revela um sertão interligado em rede, efervescente, integrado ao processo macrorregional de ocupação e urbanização do Brasil, conforme pretende Beatriz Bueno. ${ }^{40}$ A circulação de emigrantes com suas ideias e ações, sejam engenheiros ou artífices, engendrou a arquitetura setecentista da capitania, onde atuaram como agentes culturais da produção edilícia, mediada por suas histórias de vida e atuação profissional, pelas influências plásticas e técnico-científicas que transmitiam e pelos condicionantes físico-sociais dos lugares de implantação.

\section{MOBILIDADE E OBRIGAÇÕES DOS ENGENHEIROS MILITARES PORTUGUESES ENTRE O REINO E A CAPITANIA DO CEARÁ}

Entre o século XVI e o alvorecer do XIX, a mobilidade do engenheiro militar português contribuiu com a troca e a fluidez de conhecimentos técnicos e científicos, competências e estilos por todo o Reino. A trajetória de vida do profissional, movimentando-se entre os mais distantes lugares do Império, difundindo e apreendendo saberes, conectando mundos longínquos em rotas transoceânicas e percursos territoriais, ilumina o sentido global do empreendimento colonizador. A apresentação e análise de suas obrigações e ações contribuem para a compreensão das estratégias empregadas pela Coroa, conhecendo e organizando o espaço territorial e urbano da Capitania do Ceará.

Apoiada em $\bigcirc$ engenheiro português, de Manoel de Azevedo Fortes, Beatriz Bueno ${ }^{41}$ apresenta as obrigações do profissional nas praças e nas campanhas. A autora assevera que "as mãos sujas de cal e de tinta representam um perfil profissional que jamais se limitou ao gabinete, orquestrando os canteiros de obra de perto, melando as botas de lama durante as incursões de campo que precediam a elaboração de qualquer projeto ou mapa". A exposição dessas responsabilidades reverbera o largo espectro de desempenho do engenheiro militar em circulação pelo Reino. Tratava-se de uma "multifacetada atuação". Esses "homens
39. Livro $n^{\circ} 4$ da Freguesia..., op. cit.

40. Bueno (2017, p. 243).

41. Id. (2011b, p. 133-134). 
42. Id. (2011a, p. 1).

43. Id. (2011b, p. 133-134).

44. Rossa (2002, p. 167).

45. Russell-Wood (2020, p. 173).

46. Reis Filho (1968).

47. Carita (2001, p. 393). polivalentes", "braço direito das coroas europeias", estiveram envolvidos "com o grosso das obras públicas oficiais (militares, civis e religiosas)".42

Em linhas gerais, os profissionais deveriam "acompanhar os exércitos", "cuidar do estado das fortificações", "assistir as obras em curso", "tirar com precisão a planta da praça", "aprovar e desaprovar todos os projetos", "fazer igrejas, palácios de governadores, casas de câmara e cadeia, alfândegas, aljubes, hospitais, quartéis, casas de pólvora, além de projetar estradas, pontes, cais, aterros, portos, chafarizes, fontes, aquedutos e hortos botânicos" e realizar o "mapeamento do território e o projeto de cidades e vilas". ${ }^{43}$

Conforme Walter Rossa, o desempenho desses profissionais no Reino "ultrapassava em boa medida o do simples técnico de engenharia, assumindo em muitas situações papéis de representação executiva e/ou administrativa do poder central". Para o autor, o alargamento de suas funções encontra justificativa "numa estratégia territorial global da qual urbanizar era o instrumento-acção com mais potencialidade". ${ }^{44}$ Uma "presença física - uma massa crítica de portugueses medida em povoações" foi, segundo Russell-Wood, 45 "muitíssimo desejável para a promoção das políticas da coroa". Nesse sentido, Reis Filho ${ }^{46}$ considera a urbanização do território brasileiro uma etapa do processo de colonização.

Rui Carita ${ }^{47}$ ressalta "o trabalho de gestão e controlo dos engenheiros militares, não só na sua educação como tal e no planejamento de fortalezas, mas de todas as construções mais importantes da responsabilidade do erário régio", como "as igrejas e os conventos, assim como na estruturação geral dos centros urbanos, encanamentos de cursos d'água, cais de desembarque etc.". Admite que "dentro de determinados aspectos, civilizações como as da América Latina surgiram, cresceram e tomaram forma sob o impulso do trabalho constante da engenharia militar", muitas vezes de "braços dados com os jesuítas". Alguns religiosos, "também matemáticos e geógrafos, lançaram as bases territoriais e da instrução e da cultura de todo um povo". Por fim, o "delineamento de mapas de vastas regiões, muitas delas quase totalmente desconhecidas", a formação artística dos engenheiros e o trabalho "noutros domínios", pois, "iniciando os seus levantamentos pela geografia e cartografia, passam depois à arquitectura e ao urbanismo" e alcançam as chamadas "descrições", ou seja, "texłos com desenhos vários, uniformes, costumes, paisagens, criando muitas vezes outro tipo de trabalho científico, em domínios tão diversos como os da antropologia ou da botânica".

Entre os anos de 1700 e 1822, engenheiros militares foram enviados ao Ceará. Fixados ov em trânsito, adentraram os sertões e percorreram a costa cumprindo obrigações que espelhavam as funções dos profissionais em incursões pelo Reino. Os 
oficiais cartografaram o território, ${ }^{48}$ inspecionaram e projetaram o forte da Vila de Fortaleza ou partiram em busca de salitre e ouro. A Vila de Monte-Mor o Novo da América, atual Baturité, foi a única instalada sob a orientação de um engenheiro.

Destacamos a ação dos engenheiros militares Diogo da Sylveyra Vellozo, ${ }^{49}$ Luis Xavier Bernardes, ${ }^{50}$ Francisco Xavier Torres e Antônio José da Silva Paulet, envolvidos na construção do Forte Nossa Senhora da Assumpção, em Fortaleza. Importa pensar - largo trânsito dos profissionais e suas "descrições" - relatórios de vistoria de fortificações ${ }^{51}$-, anotando sobre o território, conhecendo e desenhando fortalezas, os litorais e os sertões, acompanhando obras in loco e expondo dificuldades encontradas e decisões tomadas. Em tudo transparece uma postura pragmática de engenheiro militar atento aos condicionantes físico-sociais da ocupação territorial.

Além dos quatro profissionais diretamente envolvidos com as obras do forte, estiveram no Ceará os engenheiros Custódio Francisco de Azevedo, ${ }^{52}$ Jerônimo Mendes Paz $^{53}$ e João da Silva Feijó, ${ }^{54}$ envolvidos com instalação de vila, construção de obras públicas, procura de minas de salitre, ouro e prata e elaboração de cartografia territorial. As razões pelas quais foram enviados à capitania amplificam o espectro das obrigações dos profissionais em território cearense.

\section{Os relatórios de viagem do engenheiro Diogo da Sylveyra Vellozo}

primeiro engenheiro português na Capitania do Ceará foi Diogo da Sylveyra Vellozo, ${ }^{55}$ que estudou nas Aulas de Fortificação e Arquitetura Militar em Lisboa, tendo sido aluno de Francisco Pimentel, filho de Luís Serrão Pimentel. ${ }^{56}$ Em Portugal, serviu com a patente de ajudante de engenheiro. ${ }^{57} \mathrm{Em} 22$ de fevereiro de 1702, ${ }^{58}$ foi nomeado capitão engenheiro da colônia de Montevidéu, encarregado de "desenhar e delinear a fortaleza que se há de fazer". Chegou à América portuguesa pelo Rio de Janeiro, onde se estabeleceu por três anos, não sendo enviado para Montevidéu.

Em 1707 fora nomeado para ocupar o posto de capitão engenheiro de Pernambuco, que vagou por falecimento do engenheiro Luís Francisco Pimentel em 1705. O cosmógrafo-mor do Reino, Manoel Pimentel, justifica a indicação de Diogo da Sylveyra Vellozo para o cargo, "porque como hoje se desamparou a Colonia do Rio da Prata parecem escusados quatro Engenheiros no Rio de Jan. ${ }^{\circ}$ que tantos são com o Diogo da Silveira Veloso". ${ }^{59}$

Nas Capitanias do Norte, Diogo da Sylveyra Vellozo visitou áreas remotas em várias diligências a serviço do Rei: vistoriou e desenhou fortificações, inspecionou a execução de pontes buscando melhor fluidez territorial e a construção das ermidas das
48. Sobre a cartografia cearense, ver Castro $(1997,2016$, 2018) e Jucá Neto (2016).

49. Optamos pela escrita "Sylveyra Vellozo" por ser a forma como o engenheiro assinava seu nome.

50. A documentação apresenta o nome do engenheiro como Luis Xavier Bernardo ou Luis Xavier Bernardes. Trabalharemos com Luis Xavier Bernardes.

51. Breve panorama das estruturas de defesa do litoral cearense no século XVIIII é apresentada por Carlos Studart Filho (1930).

52. Pouco se sabe sobre Custódio Francisco de Azevedo. Não há qualquer referência ao engenheiro no Dicionário histórico e documental dos arquitectos, engenheiros e construtores portugueses, de Viterbo (1988). Cf. Jucá Neto (2012b). Sobre sua ação no Ceará, mais especificamente sobre a instalação da Vila de Monte-Mor o Novo da América, cf. Castro (1997, 1999) e Jucá Neto (2011, 2012a, 2012b, 2013).

53. Não há qualquer referência a Jerônimo Mendes Paz no Dicionário histórico e documental dos arquitectos, engenheiros e construtores portugueses, de Viterbo (1988), tampouco no Expedições científico-militares enviadas ao Brasil (Id., 1962). Jucá Neto (2012a) o inclui como engenheiro (embora sua formação não esteja comprovada) diante de sua habilidade técnica ao cartografar a região das minas dos Cariris Novos. No primeiro capítulo - "Governo de Quaresma Dourado. Ouvidoria de Proença Lemos. Jeronymo de Paz. Minas de São José dos Cariris. Álvarez de Matos" - de Notas para a história do Ceará: segunda metade do século XVIII, 
Studart (1892, p. XX) escreve sobre Jerônimo Mendes Paz. Cf. também Jucá Neto (2012b).

54. Por formação, João da Silva Feijó era naturalista. Optamos por incluí-lo estre esses profissionais por sua cartografia do território cearense. Sobre Feijó, cf. Jucá Neto (2012b), Nobre (1978), Nogueira (1888), Paiva (1991) e Pereira e Santos (2012).

55. Sobre Diogo da Sylveyra Vellozo, ver proêmio de Mário Mendonça de Oliveira (2005), que comentou e transcreveu a obra do engenheiro. Cf. Viterbo (1962) e Jucá Neto (2012b).

56. Ribeiro (2009, p. 169).

57. Vellozo (2005).

58. Documento transcrito por Viterbo (1964, p. 132).

59. Consulta do Conselho Ultramarino... (1707a).

60. Requerimento do tenente-general da Artilharia... ([1746]).

61. Parecer da Junta [de engenheiros... (1729).

62. Requerimento do tenente general... ([1739]).

63. Requerimento do tenente-general da Artilharia... ([1746]).

64. Consulta do Conselho Ultramarino... (1707b). fortalezas e das capelas-mores das igrejas matrizes de longínquos povoados. Em carta de 5 de maio de 1735, quando o rei de Portugal the outorgou o posto de tenentegeneral de infantaria com o exercício de engenheiro, apresentou, em linhas gerais, sua agenda de trabalho. Àquela altura, Sylveyra Vellozo já havia servido a Coroa por "quase trinta e hum anos", considerando-se o período entre Portugal, Rio de Janeiro e Pernambuco. Em Recife, nos 23 anos em que trabalhara "com grande zello e atividade", realizara "m. . $^{\text {tas }}$ e repetidas jornadas" pelas Capitanias do Norte. Fora ao Ceará duas vezes, "huma delas no descobrim. to de huas Minas de Ouro que se Suppunha haver no Certão dos Icos mil e cincoenta Legoas por mar e terra com excessivo trabalho e discomodo". Serviu na Capitania do Rio Grande uma vez. Também uma vez na Capitania do Pará, "antes de nella haver Capitam Engenheiro". Deslocou-se "cinco vezes a fortaleza de Tamandare q dista da praça do Recife Vinte e Cinco Legoas". Visitou algumas vezes a "fortaleza da barra de ltamaracá", 53 vezes o "Forte do Pau Amarelo", 17 vezes o de "Nossa Senhora da Nazare", 11 vezes o "Cabo de Santo Agostinho", 3 vezes a "barra de Catuama" e o "Forte de Pitimbu". Às vilas de Goiana e lgarassu e aos povoados de Taquera, Ipojuca e Moribeca, deslocou-se com a incumbência de vistoriar e determinar obras de pontes e das capelas-mores das igrejas matrizes. $O$ documento revela, ainda, que o engenheiro realizou serviços no Rio de Janeiro, foi à Vila de São Paulo uma vez, duas vezes a Santos e outra à "llha Grande em tempo que se achava invadida por huns piratas Francezes". ${ }^{60}$

Em 1729, Vellozo fora enviado a Lisboa, para compor uma Junta da qual participaram o Engenheiro Mor do Reino Manoel de Azevedo Forte, o Brigadeiro João Masse e o Coronel Jose da Silva Paes, com intuito de discutir sobre as obras das fortificações da Capitania de Pernambuco; a Cidadela do Recife e os fortes do Brum, Santo Antônio dos Coqueiros, Nazaré e Quarteis de Olinda. ${ }^{61}$

Sylveyra Vellozo foi nomeado para construir fortificações na llha de Fernando

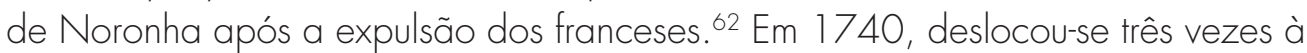
"Cidade da Parahiba", mandado "pelo Governador de Pernambuco [...] a desenhar huma nova cidadela para defensa da mesma cidade". ${ }^{63}$ Invariavelmente, a documentação real enaltecia repetidas e longas jornadas por mar e por terra do engenheiro movimentando-se intensamente entre as Capitanias do Norte.

No traslado do Rio de Janeiro para Pernambuco, o engenheiro naufragou na enseada de Vaza-Barris, tudo perdendo. Em Recife, Sylveyra Vellozo pediu ajuda de custo, dentre outras razões, "para que se the compre alguns livros para estudo da architetura militar" e instrumentos. Justificou que seriam necessários para um engenheiro ter aula e ensinar fortificação. A observação sugeriu sua intenção de lecionar arquitetura militar em Recife. ${ }^{64}$ Diogo da Sylveyra Vellozo foi lente da aula militar de Pernambuco. Escreveu Arquitectura militar ou fortificação 
moderna; ${ }^{55}$ Geometria prática Tomo I, dividido em tres tratados escritos por Diogo da Sylveyra Vellozo - Ten. de Mestre de Campo G. ${ }^{a l}$ com exercício de engenheyro na praça de Pernambuco - 1669; e Opúsculos geométricos recopilados no presente volume por Diogo da Silveyra Vellozo Ten. G.al de Infantaria com exercício de Engenheyro na Praça de Per. ${ }^{c 0}, 1732.66$

Os volumes requeridos revelam largo conhecimento da literatura especializada. Sylveyra Vellozo solicitou "Hum livro de Senos, Tangentes e Secantes"; uma dúzia do "Methodo Lusitanico" para mandar à "Bahia, Pernambuco e Angola"; "Hum tomo de Zepeda em Castelhano também de Fortificação"; as obras de "Sebastião Frz [Fernandez] de Medrano em língua Castelhana"; um livro da "Escola de Pallas"; um "tomo de artilharia de Julio Cesar Firrufino em língua Castelhana" ou, na falta deste, outro da mesma matéria composto por "S. F. de Gamboa também na língua Castelhana"; e dois tomos, em castelhano, de "Arte y Uso de Arquitetura por Fr. Laurencio de S. Nicolas". Caso não fossem encontrados, serviriam os de "Sebastião Serlio de Architectura, traduzido de Italiano em Castelhano". Também solicitou um livro de "milícia em Português composto por Luiz Mendes de Vasconcelos". Em língua francesa, requereu as obras de Ozanam. Como instrumentos, solicitou "Hú compasso, húa régua do tamanho de meyo pé

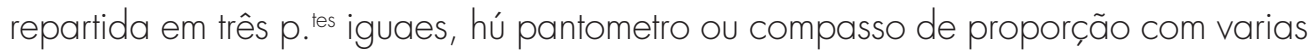
linhas riscadas nelle" e "hú semicírculo repartido em 180 graos". Segundo Vellozo, eram feitos em Paris por "hú oficial que se chama Buterfield insigne artífice", mas também poderiam ser encontrados na Inglaterra ou na Holanda. Os compassos de "meyo palmo e três quarteis de palmo" eram executados com "g. de perfeição em Inglaterra e em Holanda, e valem baratos". 67

A Coroa reconheceu a importância dos livros e instrumentos requeridos por Sylveyra Vellozo, em Recife, como também para os alunos da escola da Bahia. No caso de Recife, optou por ordenar envio de dinheiro do Conselho Ultramarino para a compra dos volumes requisitados. Os exemplares seriam adquiridos na capital pernambucana, onde se poderia comprar "m. tos que forão do Sarg. ${ }^{\text {to }}$ mor Luis Fr. co Pimentel o qual tinha hua g. ${ }^{\text {de }}$ copia de livros e instrum. tos que lá se venderão pela decima parte do que custarão". 68 Já os da Bahia deveriam vir da Holanda, pela dificuldade de encontrá-los em Portugal. A informação sugere, ainda que de maneira pontual, a circulação de livros de engenharia militar e tratados de arquitetura em território brasileiro.

Em 1713, Diogo da Sylveyra Vellozo escreveu, com visão técnico-científica de engenheiro militar, dois manuscritos de vistoria de fortificações e "reductos" na Capitania de Pernambuco e suas anexas. Os relatórios iluminam o trânsito do profissional nas Capitanias do Norte, expondo suas obrigações e intervenções nas
65. Oliveira (2005, p. 11) assevera que Arquitetura militar ou fortificação moderna saiu "provavelmente de apostilas dos alunos da aula militar do Recife e procura ser extremamente didático, montando as suas argumentações de maneira metódica e incluindo escólios destacados, quando se fazia necessário e, obviamente, muitos desenhos". Acrescenta que o texto "esbanja erudição e demonstra a boa preparação dos engenheiros militares".

66. Cf. Vellozo (2005).

67. Consulta do Conselho Ultramarino... (1707b).

68. Ibid. 
69. Os relatórios encontram-se insertos como anexos na Carta ( $2^{\text {a }}$ via) do [governador... (1713).

70. Ibid.

71. Ibid., p. 6-7.

72. Ibid., p. 7.

73. Ibid., p. 1.

74. Ibid., p. 1. fortalezas do litoral. Em linhas gerais, descreviam a arquitetura, o programa e o estado das fortificações, e apontavam algum material usado nas construções, os problemas construtivos existentes e os relativos à implantação no sítio que pudessem comprometer a defesa da costa. ${ }^{69}$ Apresentaremos as "descrições" dos fortes.

O manuscrito, a Relação dos fortes e Reductos que se achão feytos e se vão continuando nesta costa de Pernambuco e suas utilidades, fora escrito em $1713 . .^{70} \bigcirc$ documento apresentou a rede de fortificações e redutos de Pernambuco ao Ceará com considerações sobre suas serventias. Descreveu a forma da arquitetura, sua implantação, sua relação com o mar e a barra onde foram construídos, ponderando sobre a eficácia ante questões de defesa, o perigo de alcance inimigo dos povoados e a capacidade de abastecimento de água.

Em direção ao litoral sul da Capitania de Pernambuco, visitou, no Cabo de Santo Agostinho, o Forte de Nossa Senhora de Nazaré, com sua "forma quadrada irregular" e duas "batarias huma alta, outra baixa". Afirmou ser de grande utilidade para a defesa do sítio, embora "pella parte de terra está sem defença e condenado". ${ }^{71}$ Relatou, a seguir, sobre o Forte de Tamandaré, situado no "meyo de huma enseada grande, cercada de Recifes, que a fazem abrigada, capaz de estarem nella juntos vinte e sinco ou trinta navios de mediana grandez". A construção tinha a forma de um "quadrado de quatro baluartes inteyros com quatrocentos palmos de Lado de poligno exterior". Vellozo observa que o forte não impedia a entrada na barra, tampouco o desembarque de possíveis invasores - daí a existência de um reduto de areia e faxina que o "tempo demoliu".72

Em direção ao litoral norte, analisou primeiro o "forte do Brum", apontando-o como "principal defença da barra deste Recife". Possuía forma quadrada e "dous baluartes para a parte do rio e dous meyos baluartes para a parte do mar". Na visão do engenheiro, seu único problema era a inexistência de água "para se poder defender algum tempo" e a falta de espaço para a construção de uma cisterna. ${ }^{73}$

Em seguida, descreveu o "forte de S. 1o Antonio" em "sitio que chamão o buraco". O forte apresentava forma quadrada com "dous meyos baluartes para a parte de terra e outros para a parte do mar, cujos Ramais se atão com dous Revelins de huma e outra parte do Recife e cidade". Chamouthe a atenção o desenho com as proporções do "Methodo Lusitanico". Considerou-o útil à defesa da barra, embora de pouca capacidade por possuir somente "trinta e dous palmos de Largo do parapeyto a contramuralha". Como problema, assinalou que se encontrava "condenado da parte da terra". Outro defeito era ter as "defenças Laterais para a parte do mar e do Rio", e não para a parte da cidade e dos recifes, "que he por onde pode ser atacado". Carecia de abastecimento de água, como no Forte do Brum. ${ }^{74}$ 
A seguir, deteve-se no "forte de S.ta Cruz do Mar". Segundo Sylveyra Vellozo, era um pequeno recinto com forma "octagonica", tendo somente por "cada lado vinte e sete palmos e meyo". Era de grande utilidade para a defesa, pois seus tiros podiam alcançar facilmente embarcações inimigas. O forte possuía cisterna, mas a água era salgada. ${ }^{75}$

$\bigcirc$ "forte de Madre Deus" era a última povoação do Recife. Sua forma era de um "simicirculo para a parte do Rio, sobre cujo diametro se levantão dous meyos baluartes para a parte de terra". Considerava-o totalmente inútil para a defesa do porto, além de prejudicar a ancoragem dos navios - primeiro porque não defendia a barra, "pella grande distância em que the fica"76; segundo porque não impossibilitava o desembarque "em qualquer parte que o inimigo o intenta". 77

No fim da povoação de Santo Antônio, visitou o "forte das cinco pontas", que tinha quatro baluartes "inteyros com trezentos e sincoenta palmos de Lado do poligno exterior". Sylveyra Vellozo anotou que a construção fora de grande serventia quando "Recife esteve de cerco"78. Seguiu em direção ao "forte de S.ta Cruz da barra da llha de ltamaracá", que apresentava "quatro baluartes inteyros". ○ "poligno exterior he de quatrocentos pés", sendo o maior até então descrito. Julgou-o de grande serventia pela sua proximidade com o mar e a barra do rio. ${ }^{79}$

Na barra do Rio Grande, "sobre a ponta dos Recifes", "hum forte de forma quadrada, obra antiga", era de grande "utilidade para defença". Os navios acessavam a barra "tocando com as vergas na muralha", por ser essa parte do "canal mais fundo", livrando-se de "hum grande banco de area que ha da outra parte". Pela parte da terra, o morro de areia (duna) "movediça" impossibilitava qualquer construção. $\bigcirc$ forte possuía "cisterna muyto boa de que bebe todo o anno huma companhia que tem de presidio conveniência que poucas tem nesta costa". ${ }^{80}$

Óltimo forte visitado foi o da Capitania do Ceará Grande, que distava da "barra do Recife duzentas e sincoenta Legoas". Construído de pau a pique, tinha "forma quadrada de quatro baluartes inteyros muyto pequenos sem régua nem medida feytos". Para o profissional, não fora "desenhada por Engenheyro". Sua principal "serventia" era "conservar debaixo dele domestico o gentio aldeado e enfrear o decorço". Diogo da Sylveyra Vellozo pautou sua decisão quanto à reconstrução ou não do forte em razões de cunho econômico e geográfico. Argumentou a grande distância e dificuldade de acesso por terra e mar. $\bigcirc$ engenheiro considerou desnecessário refazê-lo em pedra e cal pela falta de materiais, pelo custo da obra e, ainda, por julgar "inútil e desnecessária como são todas aquellas que não fazem conseguir o fim para que se mandão fazer". Para Vellozo, três razões justificariam sua reconstrução. A primeira seria "a defença de alguma barra". Considerou que no
75. Ibid., p. 1.

76. Ibid., p. 1.

77. Ibid., p. 1-2.

78. Ibid., p. 3.

79. Ibid., p. 4.

80. Ibid., p. 5. 
81. Ibid., p. 5-6.

82. Ibid., p. 6.

83. Os relatórios encontram-se insertos como anexos na Carta ( $2^{\mathrm{a}}$ via) do [governador... (1713). op. cit.

84. Ibid., p. 1. sítio da fortificação não havia qualquer barra, "nem em cem légoas em Roda, tirando a de Jaguaribe em que só entram sumacas pequenas, porque tudo o mais é costa direyta com muytas e boas enseadas". A segunda seria impedir o desembarque de inimigos, mas acreditava não haver sentido nisso, pois o desembarque poderia ser feito em qualquer enseada da costa sem a proteção do forte. E a terceira, "defender a povoação se a houvesse". Segundo ele, não havia razão em defender um núcleo de "sinco cazas de barro cobertas de palha cujas riquezas constão de uma rede e hum cachimbo e hum banco se o há"..$^{81}$

Portanto, não havia sentido em "fazer huma obra que com cem cruzados se não havia de acabar". $\bigcirc$ engenheiro também não cria que, com o tempo, à "sombra da fortaleza" concorressem "moradores a fazer cazas e assento na villa". Na capitania não havia "outro negócio mais que a criação de gados", nos longínquos sertões. Para Sylveyra Vellozo, quem seguia ao Ceará não ia para morar, tampouco para garantir pouso na vila, e sim para os sertões em busca dos "currais que estão sincoenta, cem, duzentas Legoas pella terra dentro, isto tem mostrado a experiência de tantos anos". Tudo era muito distante, e o acesso deveras difícil. Por mar, levava-se, no caminho de ida, até dois meses. Recomendou "não cuydar na obra de pedra e cal, mas só em Reparar a que esta feyta, em melhor forma, que não só he o que basta, mas ainda o que sobeja para aquelle sitio". ${ }^{82}$

Em 1712, Sylveyra Vellozo já havia escrito outro manuscrito intitulado a Relação dos fortes e Reductos que se achão feytos na Cappitania de Pernambuco, estado em que estão e o que the faltava para se porem em sua ultima perfeição, ${ }^{83}$ relatando, com acuidade técnica, sobre o andamento das obras e os materiais necessários para a finalização das construções.

O engenheiro declarou que no Forte do Brum faltava concluir o fosso, "levantar e engrossar mais os parapeytos da parte da terra, fazendo-thes banquetas entre as canhoeyras por que joga a artilharia", fazer "alguns concertos [...] nas guaritas e ladrilhar [...] a abobeda da casa da pólvora", evitando-se humidade. No Forte de Santo Antônio, restava fazer algum "terrapleno no Revelim da parte da Cidade", "reformar o lagedo da explanada da cortina e meyo baluarte da mesma parte, que olha para a barra", assentando-o "sobre bom massame de pedra e cal", além de "levantar os parapeyłos da parte da terra" e fazer "banquetas entre as canhoneyras". Quanto ao Forte do Mar, relata que a construção passara por recentes reformas nas "esplanadas das artilharias" e nos "parapeytos". No Forte de Nossa Senhora da Madre Deus, faltavam "parapeytos" e "terraplenos", e as muralhas encontravam-se sem a "devida altura" e sem parte dos "flancos e da cortina". ${ }^{84} \bigcirc$ Forte Cinco Pontas encontrava-se acabado. No de Pau Amarelo, fora iniciada uma "bataria para defença da barra". Encontrava-se pronto "hum lanço de 
muralha de cem palmos de comprido, e quazi outro tanto de contra muralha". $\mathrm{Na}$ Fortaleza de Santa Cruz da barra da llha de Itamaracá, a muralha achava-se acabada, com "parapeytos e guaritas". Encontravam-se em obra "duas contramuralhas", "parte da porta", "corpos de guarda, armazens e mais obras interiores", "explanadas de lagedo e outras de madeyra" em que "joga a artilharia". 85 $\mathrm{Na}$ "fortaleza do Cabedello da barra da Parahiba", a muralha exterior encontravase pronta. As obras prosseguiam nos "corpos de guarda", nas guaritas e na remoção de "terraplenos antigos para se andar com as contramuralhas, quarteis, armazens, hermida e cisterna". ${ }^{80}$ No Rio Grande, a fortificação estava acabada, necessitando de "novas explanadas para jogar a artilharia". No Ceará, a fortaleza de "pao a pique" carecia de "reformação como tambem as explanadas de madeyra em que joga a artilharia que estão de tudo incapazes". ${ }^{87}$

Em direção ao litoral sul, Sylveyra Vellozo considerou que, no Forte de Nossa Senhora de Nazaré, as "explanadas ou Leytos da artilharia" achavam-se menos capazes. $\bigcirc$ Forte de Tamandaré achava-se parcialmente pronto, com os "madeyramentos dos quarteis, hermida, casas do cabo e da pólvora" reformados. Ele alertava, contudo, que as "explanadas de lagedo" encontravam-se "incapazes" e para a necessidade de "se the levantarem os parapeytos da parte de terra". ${ }^{88}$

Em todas as fortificações, o maior problema residia na falta de pedras para construção. Daí porque Sylveyra Vellozo aconselhou o envio, do Reino, de "lagedo [...] já lavrado de hum palmo, ou três quartos de palmo ao menos". Ele esclarece que o material proveniente de Portugal era "muyto melhor, e de mais duração", enquanto o produzido em Pernambuco, de "área congelada com agoa salgada", se desgastava e se desfazia facilmente. Argumentou que poderia ser transportado "sem custar frete, trazendo nos navios em Lugar do Lastro que comprão". Acrescentou que o mesmo ocorria para o Rio de Janeiro, com remessas de pedra. Também os preços eram inferiores em Portugal, sendo "exorbitantes" em Pernambuco. Julgava ser mais importante "haver prontamente Lagedo para se acabar a obra", sendo muito "dificultoso de achar" em Pernambuco, pois os "Recifes donde se tira estão quazi exaustos".89

As vistorias de Sylveyra Vellozo reafirmam a importância das fortificações como estruturas de defesa da Coroa nas Capitanias do Norte, bem como expõem largo panorama de suas atividades de campo como engenheiro, transparecendo grande conhecimento de arquitetura militar e construção. Além de descrever os fortes e os redutos e informar sobre o estado das construções, os relatos assumem caráter de proposição, indicando soluções para os problemas de implantação e construtivos. Algumas das fortificações atendiam ao "Methodo Lusitanico"90 e estavam, invariavelmente, situadas nas barras dos rios e enseadas, em regiões portuárias, próximas a aglomerados. Nesse sentido, o engenheiro assevera que algumas
85. Ibid., p. 2.

86. Ibid., p. 2-3.

87. Ibid., p. 3.

88. Ibid., p. 3.

89. Ibid., p. 3.

90. Cf. Pimentel (1993). 
91. Cf. Viterbo (1962).

92. Documento transcrito em Viterbo (Ibid., p. 47)

93. Requerimento do tenente de mestre-de-campo... ([1747]).

94. Chancelaria Dom João V (1716, p. 50v). Documento transcrito em Viterbo (1962, p. 46).

95. Requerimento do tenente de mestre-de-campo... ([1747]).

96. Documento transcrito em Viterbo (1962, p. 48).

97. Consulta do Conselho Ultramarino... (1735).

98. Carta do [governador da Capitania... (1747). fortificações eram viáveis, e outras não. Quanto aos materiais de construção, faz menção a pedra e cal, e aconselhava trazer "lajedos" do Reino. Embora não o explicite, a complexidade das técnicas construtivas denota a existência de uma cadeia de artífices envolvidos no trabalho com a pedra, a madeira, a alvenaria de tijolo e a taipa. No caso do Ceará, o engenheiro pondera que a distância e o pouco adensamento populacional no entorno do forte, associado à atividade da pecuária nos sertões, não justificavam a sua reconstrução em pedra e cal.

\section{O engenheiro Luis Xavier Bernardes: vistoria do forte na Vila de Fortaleza}

Na primeira metade do século XVIII, a agenda de trabalho de Luis Xavier Bernardes ${ }^{91}$ nas Capitanias do Norte evidencia sua grande mobilidade no território e suas obrigações como engenheiro. Ele percorreu longas distâncias em tempos distendidos, orquestrou obras, desenhou fortificações e muitas vezes ajustou contas "por não haver Off. al da Ouvidoria, q' o fizesse". Entre 1712 e 1747, o profissional circulou por Portugal e pelas capitanias da Paraíba do Norte e de Pernambuco, no Brasil. ${ }^{92}$

Como ajudante de engenheiro na província de "Traz os Montes", antes de ser enviado para o Brasil, fora encarregado de "copear as Plantaz" da dita província; de coordenar obras na fortificação das praças de Miranda, Monte Alegre e Chaves; e de assistir à construção de "hu meio baluarte" na "Puebla de Senabria", no Reino de Castela. ${ }^{93}$

Em 5 de fevereiro de 1716, foi nomeado capitão engenheiro da Capitania da Paraíba para "assistir continuamente as obras das fortificações [...] e se evitar com sua assistência o erro que sem ella se pode experimentar nas medydas pellos pedreiros". 94 Em território paraibano, esteve na regência de trabalhos da "Fortaleza do Cabedello", delineando "obras interiores e exteriores". Na Baía da Traição, determinou o lugar mais conveniente para a construção de um novo forte..$^{95} \mathrm{Em}$ companhia do brigadeiro João Masse, visitou "as costas e fortalezas de Pernambuco ajudando [...] a tirar plantas de todas elas".96 Em 1733, seguiu para a Capitania do Rio Grande, "p. averiguar as desp. as $q$ " se the tinhão feito nas obras da d. ${ }^{\text {a }}$ Capp. nia". No mesmo ano, retornou à Cabedelo e, mais uma vez, trabalhou nas obras da fortificação, fazendo "parapeytos" e montando seis peças de artilharia. ${ }^{97}$

No ano de 1736, passou a servir na Capitania de Pernambuco, com cargo de tenente de mestre de campo de infantaria. Em Recife, trabalhou com o "Fr. Estevam do Loreto Religioso Benedito que hera hum Excelente Inginhr.". 98 Entre os anos de 1738 e 1740, retornou ao Rio Grande para examinar obras na fortificação. 
Em 1746, foi à Capitania do Ceará com a missão de "reedificar de novo" o forte de madeira da Vila de Fortaleza. As anotações de Luis Xavier Bernardes sobre o estado de ruína da fortificação cearense corroboram as observações de Diogo da Sylveyra Vellozo e expõem a situação de abandono da construção. $\bigcirc$ engenheiro vistoriou o forte arruinado, propôs a edificação de um novo, anotou o que viu na costa e no sertão cearenses e descreveu enseadas e barras no litoral. Sobre os sertões, explanou que entre "huas Serras se tinhão descuberto alguas faíscas de ouro", e "se pos em dilig. a de se certificar buscando a pessoas q' o sabiao e com ellas foy ao lugar". ${ }^{99}$

Em 17 de novembro de 1746, escreveu o relatório sobre a vistoria da fortaleza existente e projetou uma nova na capitania cearense. ${ }^{100}$ No traslado, anotou locais possíveis para ancoragem entre o Rio Grande e o Ceará. $\bigcirc$ texto foi acompanhado da Planta da Costa do Ciara grande daponta do Mucuripe the Jacaracanga. ${ }^{101}$

No litoral leste do Ceará, o engenheiro observou, primeiro, a foz do Rio Jaguaribe. Era a "maiz frequentada de barcos" que "vão ao negócio de carnes e ordinariamente dão fundo em um lugar chamado Retiro". Ainda assim, identificou a impossibilidade da ancoragem de navios de maior porte "por ser lodo e em outras partes pedras". ${ }^{102}$ A quinze quilômetros da embocadura do rio, encontravase o povoado de "Portos dos Barcos", elevado à condição de Vila de Santa Cruz do Aracati em 1748, por razões econômicas e de aplicação de justiça. ${ }^{103}$

Em seguida, Luis Xavier Bernardes fez considerações sobre a enseada do Mucuripe. ${ }^{104} \mathrm{Na}$ visão do engenheiro, sua situação era a mais adequada para a implantação do forte. A escolha pautou-se em três razões. Primeiro não encontrou no litoral do Ceará outros portos favoráveis para boa atracação. Como "prático da embarcação", observou as enseadas atento não aos lugares possíveis para "fazer desembarques", pois em quase "toda a costa do Brasil, se pode lançar gentes", mas aos locais onde os navios podiam "com acolhimento do tempo subsistir". Ponderou que na costa do Rio Grande era possível "estar ancoradas as embarcações". Já no Ceará, embora fossem vários os locais de "desembarques", eram poucos os lugares onde os navios poderiam aportar com segurança. ${ }^{105} \mathrm{No}$ setor leste da costa, entre o Jaguaribe e o Mucuripe, o engenheiro não fez alusão a nenhum local possível para se ancorar. Na direção oeste, percorreu do Mucuripe até a foz do Rio Mundaú. Nesse percurso, averiguou situações que apresentavam possíveis condições favoráveis para a implantação de um novo forte. Visitou as fozes do "Parazinho", "sem comodidade"; do "Pará", com "amparo para os ventos", mas sem profundidade adequada para navios; e a "barra do Rio Curu", estreita e com pedras. ${ }^{106}$ Argumentou que, no Mucuripe, não existiam obstáculos como os da foz do Jaguaribe. Não havia o inconveniente de pedras, lodo, nenhum processo de assoreamento, e apresentava
99. Requerimento do tenente de mestre-de-campo... ([1747]).

100. O relatório inserto como anexo na Carta do [governador da Capitania... (1747).

101. Studart (1923, p. 347). Mapa número 17 da coleção do Barão de Studart.

102. Relatório inserto como anexo na Carta do [governador da Capitania.... p. 1.

103. Cf. Jucá Neto (2012b).

104. Hoje a cidade de Fortaleza.

105. Relatório inserto como anexo na Carta do [governador da Capitania.... p. 1.

106. Relatório inserto como anexo na Carta do [governador da Capitania.... p. 2. 
107. A enseada do Mucuripe encontra-se a meio caminho no longo percurso entre o Rio Grande e o Maranhão, sendo lugar geográfico favorável ao pouso.

108. Carta do [governador da Capitania..., op. cit.

109. Relatório inserto como anexo na Carta do [governador da Capitania.... p. 3.

\section{Ibid.}

111. Carta do capitão-mor do Ceará... (1744).

112. Livro de registro de provisões... (1548-1821).

113. Cf. Jucá Neto (2012b). boa profundidade. Por fim, declarou que a enseada do Mucuripe ${ }^{107}$ fora o primeiro lugar de fixação portuguesa na costa cearense. ${ }^{108}$

Luis Xavier Bernardes relatou que, para a "segurança e recolhimento dos soldados", havia sido construída "huma estacada de madeira com o nome de Fortaleza e huns quarteis de terra [...] guarnecida com sete peças de Campanha". 109 Sabemos da existência da paliçada de madeira desde o alvorecer do século XVIII, por meio do relatório de viagem do engenheiro Diogo da Sylveyra Vellozo. De acordo com Xavier Bernardes, a construção de madeira fora reedificada várias vezes. Na ocasião da vistoria, o forte encontrava-se em ruína, sendo impossível fazer uma planta "q' os olhos não percebera". Tudo não passava de "huns quarteis quase destroidos e huma cadea de pao a pique", servindo de "Sintinelas de soldados". ${ }^{110}$ Antes da visita de Luis Xavier Bernardes, o capitão-mor do Ceará escreveu a D. João V, em 20 de junho de 1744, ${ }^{111}$ expondo a necessidade de construção da fortaleza, pois o reduto de pau a pique construído no "tempo da conquista destes sertões, e guerra do gentio", achava-se de "todo descampado". Em 28 de setembro de 1745, 112 o rei de Portugal ordenou o envio de engenheiro militar ao Ceará visando à elaboração de "planta da Fortaleza, q nella se necessita por se achar arruinada". Por toda a segunda metade do século XVIII, a documentação real reafirma o estado de ruína em que se encontrava a fortificação da Vila de Fortaleza e o povoado, além da ausência de engenheiros na Capitania. ${ }^{113}$

Espacializando sua vistoria à fortaleza do Ceará, o engenheiro Luis Xavier Bernardes apresentou a Planta da Costa do Ciara grande daponta do Mucuripe the Jacaracanga com trecho da costa cearense correspondente à enseada e, em detal he, o desenho do novo forte. $O$ desenho e a escrita devem ser pensados em conjunto. Na Planta, o risco da enseada como figuração geográfica e o projeto da nova fortificação reforçam a escolha do Mucuripe para a implantação da nova estrutura de defesa (Figura 2).

A visada da enseada foi desenhada a partir do mar. Em primeiro plano, vê-se o mar e recifes bipartidos. Em segundo, o intervalo de praia com o desenho da Vila de Fortaleza à direita e, na ponta esquerda, o lugar de implantação do novo forte. Ao fundo, há dunas com parca vegetação, abraçando a enseada. $\bigcirc$ desenho tem escala gráfica e indicação do norte. A legenda designa com "A" o local chamado "Mocuripe"; "BB" onde era possível o "Dezembarque em maré vazia e lugar que deve ser fortificado com o forte"; "CC" a "Barra velha de que hoje senam pode usar"; "D" o "Lugar onde houve huma estacada de madeira he a villa do Ciarã; e "F" o "Petipe thomado em braças para a costa, e pella parte de sima em palmos para a nova obra e para as partes do perfil o que sam des palmos se tomara por hum para se ir no conhecimento da sua altura" (Figura 2). 


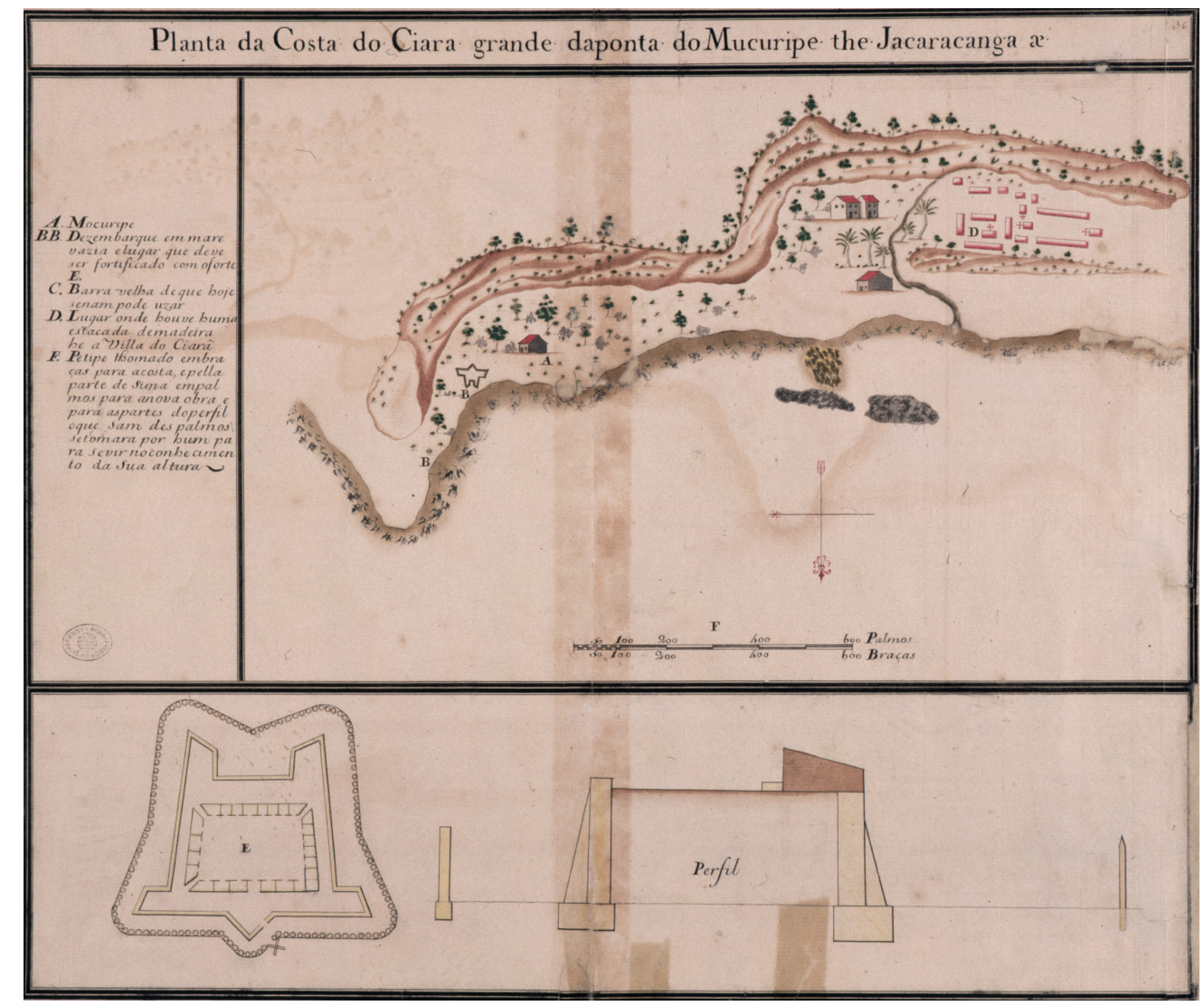

Figura 2 - Engenheiro Luis Xavier Bernardes. Planta da Costa do Ciara grande daponta do Mucuripe the Jacaracanga (séc. XVIII). Fonte: Acervo do Arquivo Histórico Ultramarino.

$\bigcirc$ engenheiro justifica os pontos demarcados. $\bigcirc$ espaço definido com "A" era de onde melhor se "defende as embarcações das violências dos ventos". Era "limpo o fundo [do mar] e com quarenta palmos de agua perto de terra em baixa mar". Em seu entorno, as "lanchas" desembarcavam nos lugares marcados com as letras "BB", pois em "toda a mais parte he cercada a praya de pedras, sem q' admitta chegar em Mare alguma". Aportavam "em baixa mar" com "agoa pella cintura". A vila se encontrava na letra "C", não indicada na Planta, embora o desenho explicite sua localização. No lugar da letra "D", informava-se onde se achava "a fortaleza com huns quarteis e huma Capela de Nossa Sr. a da Assunpção", na ocasião em ruínas. Defronte o lugar do antigo forte, "se descobre a P.e ao mar", e pela sua "aberta entravão algum dia pequenos barcos, o q' hoje não Subcede, porq' além de ser estreyła", encontrava-se "sempre debayxo da agoa". Por tais razões, Luis Xavier Bernardes propunha a atracação das embarcações no Mucuripe - letra "A" -, lugar de implantação do novo forte, a certa distância da vila. 
114. O traçado da cidade de Fortaleza só apresenta alguma regularidade no início do século XIX, com o engenheiro Antônio José da Silva Paulet. Cf. Andrade (2019) e Jucá Neto (2012b).

115. Castro (2005, p. 35).

116. Carta do [governador da Capitania... (1747).

117. Cf. Jucá Neto (2012b).

118. Requerimento do tenente de Artilharia... ([1801]).

119. Decreto do príncipe D. João... (1799).
A vila foi representada à margem do riacho Pajeú, com um descampado, uma grande área central vazia, de forma retangular, ladeada na porção maior do retângulo por casas dispostas em linha reta. Em cada lado menor do polígono, havia a indicação de estruturas religiosas. No entorno imediato da área central, figuravam poucas casas com algum alinhamento e outras dispersas, sem ordenamento. A documentação escrita do período não faz qualquer menção a uma vila com sintomas de regularidade em seu traçado no século XVIII. ${ }^{114}$ Quanto ao tipo das habitações, Castro assevera que o desenho em nada correspondia à realidade. As edificações eram "infiéis às verdadeiras dimensões do casario, à parte a apresentação de sobrados, tipologia arquitetônica que somente veio a ser desenvolvida no começo do século XIX". 115

A fortaleza proposta por Xavier Bernardes tinha um muro de contorno, em pedra e cal, circundado por outro de madeira. Apresentava reentrâncias regulares sem bastiões de defesa. $\bigcirc$ engenheiro propôs "flancos p. ${ }^{a}$ sua defença, evitando assim o Superfluo, o gasto de outra qualquer fig. ${ }^{a} q$ ' se fizesse, com o pretexto de mais flanqueada". Ainda de acordo com Xavier Bernardes, "não obstante dizerce q' daquelas partes não havia pedras de cal e alvenaria", a igreja da vila estava sendo fabricada com esse material retirado da praia. Ele informou não haver mestres pedreiros, sendo a obra tocada por "hum preto que seguia as normas do vigário". Diante da situação, ofereceu seus serviços para a execução dos quartéis "só perfiz", da igreja e da cadeia ao preço "de oito mil rs a braça [...] dois tostões o palmo de Cantaria e quatro patacas a vara do lagido". ${ }^{116}$ Não foi possível confirmar se o profissional executou essas obras.

\section{Engenheiro Francisco Xavier Torres: vistoria do forte da Vila de Fortaleza}

Cinquenta anos após a vistoria de Luis Xavier Bernardes, o engenheiro Francisco Xavier Torres apresentou novo relatório sobre o estado da fortificação na enseada do Mucuripe, no Ceará. A ausência de vistoria no forte por algum engenheiro durante meio século corrobora o argumento do pouco investimento de técnica e capital por parte do Estado português na organização do espaço da Capitania. ${ }^{117}$

Francisco Xavier Torres nasceu em Coimbra. ${ }^{118}$ Em janeiro de 1799, sendo então sargento-mor da Companhia de Pontoneiros e Artífices do Regimento de Artilharia da Corte, foi promovido, por oito anos, ao posto de primeiro-tenente da Artilharia da Capitania do Ceará. ${ }^{119}$

Em $1^{\circ}$ de janeiro de 1801, Xavier Torres enviou ofício ao secretário de Estado dos Negócios da Marinha e Ultramar, D. Francisco de Sousa Coutinho, descrevendo 
vistoria feita nas fortificações da Vila de Fortaleza e do Reduto de São Luiz, na ponta da enseada do Mucuripe, no qual relatava a necessidade de construir uma nova casa de pólvora. ${ }^{120} \mathrm{O}$ engenheiro representou graficamente o forte (Figura 3).

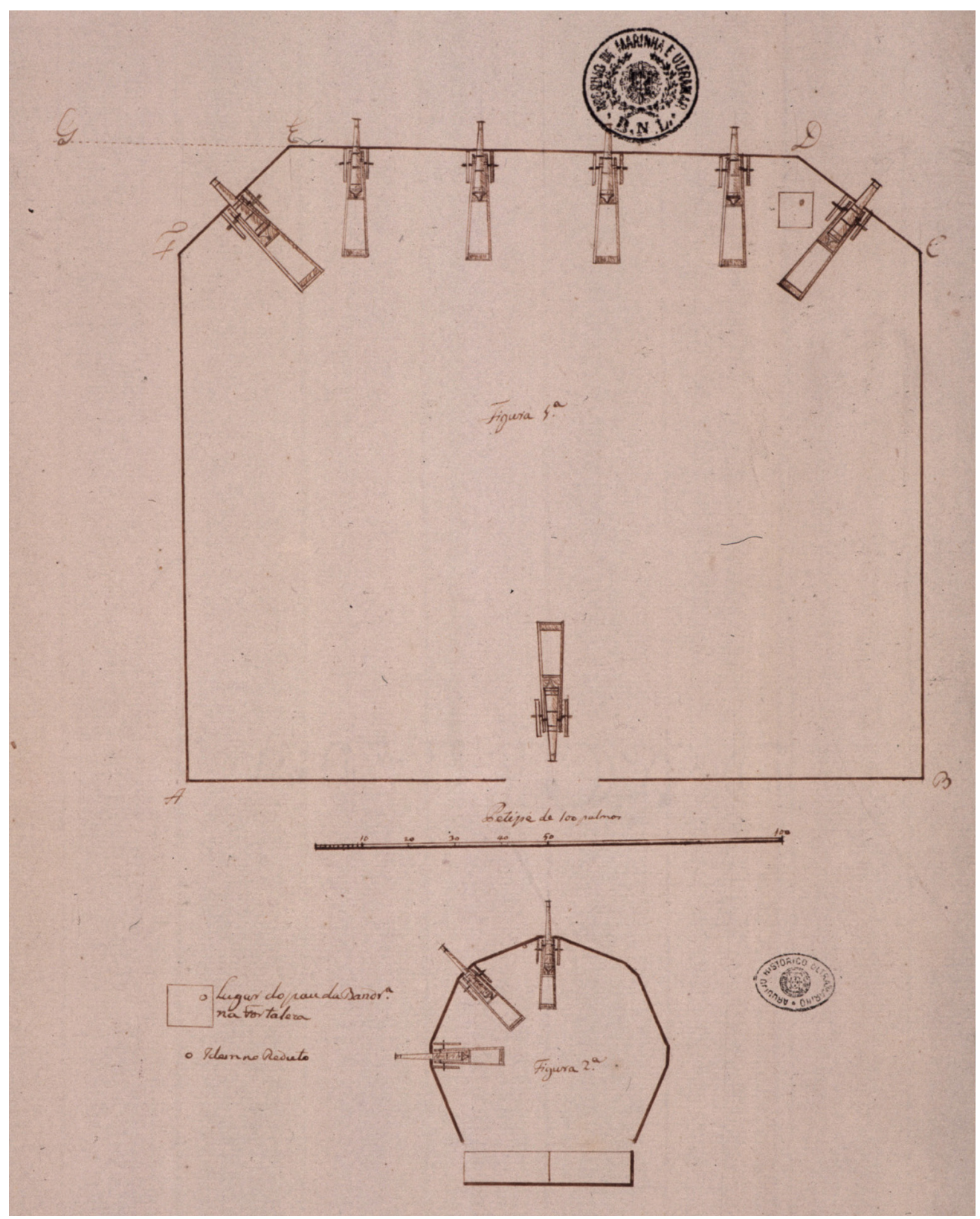

Figura 3 - Engenheiro Francisco Xavier Torres. Desenho de Fortim e Reduto de S. Luiz, na enseada do Mucuripe (c. 1800). Fonte: Acervo do Arquivo Histórico Ultramarino.
120. Ofício do tenente comandante... (1800). Cf. Jucá Neto (2012b). 
121. Ofício do tenente comandante... (1800). p. 1.

122. Ibid.

123. Castro (2005, p. 42).

124. Pimentel, op. cit.

125. Castro (2005, p. 42).

126. Ofício do tenente comandante... (1800). p. 2
Em sua descrição, Xavier Torres assevera que o fortim estava em ruínas e que fora construído de "terra e faxina", não passando de um "simples Parapeito sem canhoneiras" voltado para o mar. Os canhões, também arruinados, achavam-se a "barbeito da Fortificação". Eram "7 peças huma de bronze de calibre 7, e 5 de ferro de diferentes calibres a saber, huma de calibre 9 , outra de 8 , três de 6 e huma de 5". Todas as peças estavam bastante deterioradas. A pequena fortificação servia "unicamente para defender o desembarque na Praia fronteira". Na face voltada para a enseada estavam dispostos quatro canhões. Em cada lado contíguo a essa face havia mais uma peça de artilharia, e outra na parte posterior, em direção à vila. ${ }^{121}$

Em caso de reedificação, o engenheiro propunha alongar o lado "DE", na direção da letra "G", sentido oeste, aumentando a linha de defesa defronte ao mar. Ele afirma que havia terreno para sua ampliação, sendo possível a acomodação de "duas peças em cada um dos dois lados, contíguos a ella para efeito de baterem na Praia para hum e outro lado". 122 Tomando como base o petipé de 100 palmos indicado no desenho, Castro assevera que a "planta quase quadrada" tinha "160 palmos de frente e 135 de palmos de lado", com "ensutamento nos cantos de frente em torno de 22 palmos", "uma frente de $35,20 \mathrm{~m}$ por 29,70 m, de lado, e um ensutamento de 4,84 m nos cantos, cobrindo uma área total de $1.045 \mathrm{~m}^{2 "} .{ }^{123}$ Considerando suas dimensões reduzidas, Castro acrescenta que a construção era um "mero reduto", seguindo a classificação de Serrão Pimentel, ${ }^{124}$ aplicada a "obra menor quadrada ou algum tanto prolongada". ${ }^{125}$

Segundo Xavier Torres, o Reduto de São Luiz, na ponta do Mucuripe, era um octógono regular, com 20 palmos de extensão em cada lado. Consistia de "hum parapeito de estacas grossas pregadas no chão em huma só ordem", perfazendo a "grossura do mesmo parapeito". Defronte ao mar, havia "sinco ângulos" com "huma canhoneira" e, na direção oeste, setor voltado à enseada, "3 peças de calibre 3, duas de bronze e huma de ferro, todas com os ouvidos arruinados". Para a parte da terra, três ângulos formavam "a sua goleira com o quartel", onde se acomodava a tropa. ${ }^{126}$

No lugar do fortim, Francisco Xavier Torres defende a necessidade de uma fortificação permanente, por "dominar a entrada na enseada do Mucuripe", e assevera ser este o "melhor ancoradouro", protegendo as embarcações dos ventos provenientes da direção leste. Tal argumento já havia sido exposto pelo engenheiro Luis Xavier Bernardes em sua descrição da enseada e do forte, datada de 1756. A despeito da distância de aproximadamente meia légua entre o fortim e o porto de desembarque, defronte à vila, Xavier Torres considerou ser aquele o melhor lugar de ancoragem pela garantia de defesa que o fortim promovia. Tratava-se de "um grande morro de areia", "cujas faldas" eram terreno fixo, voltado para a enseada, para a vila e protegido dos ventos. Daí porque recomendou "oito peças, todas de 8 e 12", 
cobrindo a pequena baía. Diante da extensão da enseada, com muitos lugares de desembarque, o engenheiro propunha, ainda, a existência de "ao menos oito pessas de campanha das mais ligeiras, quatro de calibre 6 e quatro de calibre 3", de "fácil transporte", e que alcançasse "qualquer ponto atacado". ${ }^{127}$ Seria necessário, também, o uso de "Bandeiras de Signais" para, em caso de ataques, comunicá-los à vila, e "dois óculos": um para observar do fortim as "embarcaçoens que aparecem", e outro, no forte da vila, para observar "os signais que do dito Reduto se fizerem". ${ }^{28}$

Francisco Xavier Torres propôs a construção de um "Paiol de Polvora". $\bigcirc$ existente encontrava-se no "Aquartelamento" da vila, dentro de um "Armazem em que se goardão espingardas, balas e todos gêneros da Fazenda Real". Defendeu a construção de "hum Paiol próprio para a Polvora" fora do núcleo, diante do perigo de explosão, que "há de arruinar" a "maior parte" do aglomerado. ${ }^{129}$ A nova casa da pólvora seria um pequeno conjunto constituído por uma parede de proteção externa e um núcleo central, a casa da guarda, onde estaria o material. A casa da guarda ficaria a uma distância de 100 palmos da parede externa (Figura 4).

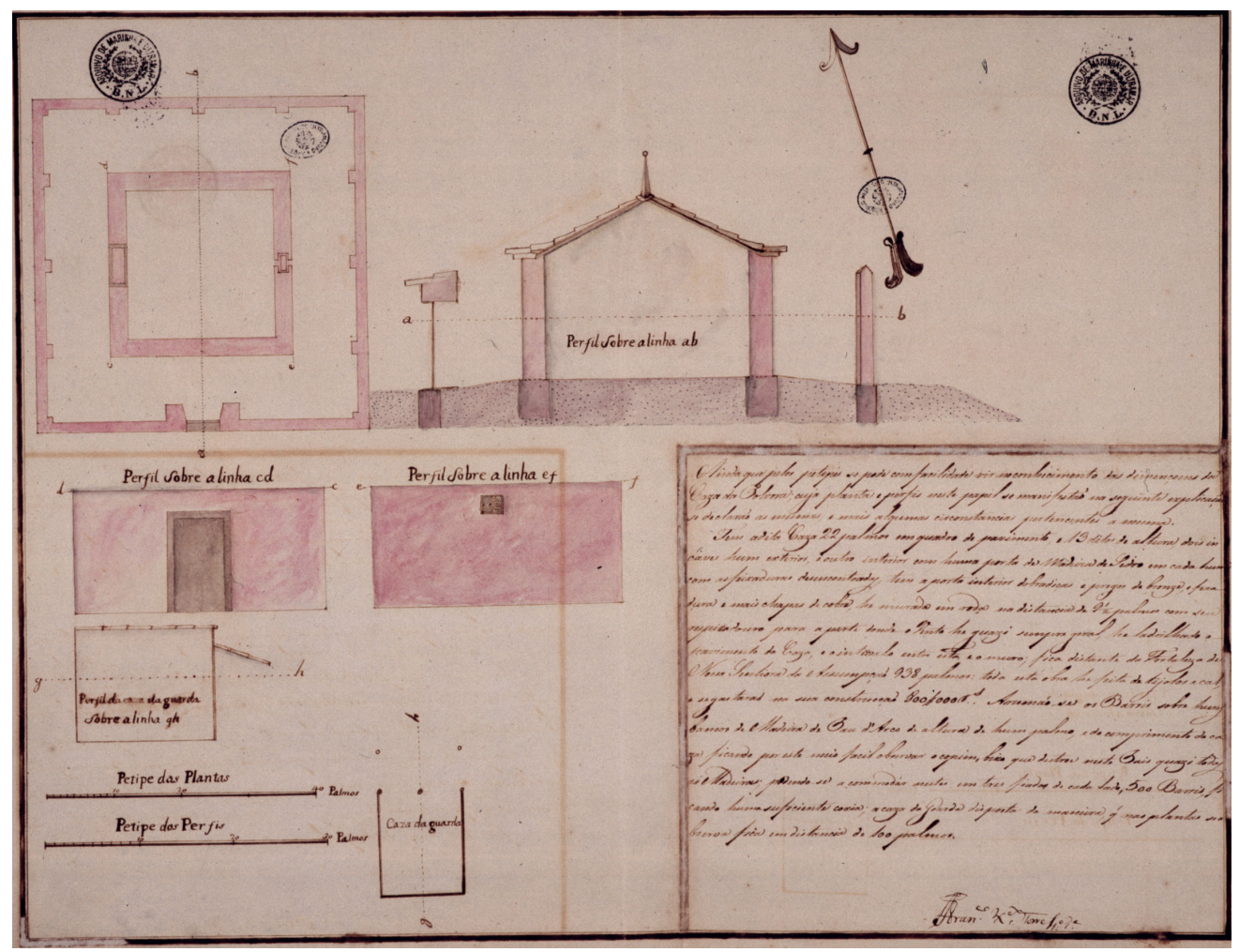

Figura 4 - Engenheiro Francisco Xavier Torres. Projeto da Casa de Pólvora. Fonte: Acervo do Arquivo Histórico Ultramarino.
127. Ibid.

128. Ibid., p. 3.

129. Ibid. 
130. Viterbo (1964, p. 39).

131. Castro (2012b, p. 18)

132. Castro (2012b, p. 18); Jucá Neto (2012b, p. 146).

133. Cf. Menz (2001).

134. Cf. folhas avulsas do Maço Silva Paulet no Arquivo Histórico do Exército, em Lisboa.

135. Castro (2012b, p. 18-19).

136. Cf. Castro (2012b); Jucá Neto (2012b).
O desenho da casa de pólvora indica a direção do norte e apresenta planta baixa, fachada, corte do edifício e petipé de 40 palmos para as plantas e de 30 palmos para os perfis. Não esclarece, contudo, o lugar exato da implantação da construção. De acordo com a descrição do projeto na cartela, situada no canto direito do risco, a casa da pólvora distava 928 palmos do forte existente e tinha 22 palmos em quadro e 13 palmos de altura. Seria guarnecida por duas portas de cedro com "feixaduras desencontradas" - a porta interna com "dobradiças e pregos de bronze", fechaduras e "mais chapas de cobre". As paredes externas deveriam ter 9,5 palmos. Na fachada leste, haveria um "respiradouro" no topo da alvenaria. A construção seria de tijolo e cal, e o piso ladrilhado. Os barris de pólvora estariam dispostos sobre "bancos de madeira de Pau D'Arco de altura de hum palmo", no comprimento da construção. Cerca de 500 barris poderiam estar dispostos em "três fiadas de cada lado, [...] ficando huma suficiente coxia". $\bigcirc$ artifício dos bancos altos protegeria os barris da ação dos cupins. O forte descrito por Francisco Xavier Torres foi substituído pela atual Fortaleza de Nossa Senhora da Assumpção, projetada pelo engenheiro militar Antônio José da Silva Paulet.

\section{O engenheiro Antônio José da Silva Paulet e o projeto da Fortaleza de Nossa Senhora da Assumpção}

O engenheiro Antônio José da Silva Paulet nasceu em Portugal, em 1778, na Villa de Nogueira de Azeitão. ${ }^{130}$ Chegou ao Brasil na "armada que trouxe a família real". ${ }^{131}$ Para o Ceará, veio como ajudante de ordens do governador Manoel Ignacio de Sampaio, em $1812 .{ }^{132}$ Em fevereiro de 1820, foi nomeado pela Secretaria de Estado dos Negócios Estrangeiros e da Guerra para comandar a Província de Missões. ${ }^{133}$ De volta a Portugal, instalou-se na cidade do Porto, onde ocupou, entre outras funções, as de "Governador interino do Castello de São João da Foz do Porto" e "Director das Obras da Barra e Caes do Douro". 134

De acordo com Castro, no Porto, Antônio José da Silva Paulet teve participação ativa na "Guerra Civil, travada entre o exército formado por constitucionalistas liberais, comandado pelo Imperador Pedro I, e as facções absolutistas, postas sob as ordens de seu irmão, Dom Miguel". O autor destaca sua presença no "prolongado cerco da cidade do Porto, como comandante do quartel do Trem [de Artilharia] do Ouro", lugar estratégico no "abastecimento alimentar e bélico da Cidade, ponto de ligação desta com o setor de suprimento marítimo, na foz do rio Douro". 135

No Ceará, esteve à frente de obras públicas, cartografou o território, desenhou e descreveu vilas. ${ }^{136}$ Em Fortaleza, projetou e construiu o "mercado novo, 
um chafariz e a nova Fortaleza de Nossa Senhora da Assunção", prosseguiu com os "trabalhos de batimetria do porto" e elaborou o "primeiro plano de urbanização [da vila], em quadras retangulares, semelhantes às da Baixa lisboeta". ${ }^{137}$

Em 1812, logo após sua chegada ao território cearense, Silva Paulet foi encarregado de cartografar a capitania. $\bigcirc$ governador Sampaio o incumbira de desenhar com "suficiente exactidão o litoral cearense", registrando de "maneira positiva a posição geográfica da costa". ${ }^{138} \bigcirc$ engenheiro desenhou, inicialmente, a Carta da Capitania do Ceará e costa correspondente levantada por ordem do Governador Manoel Ignacio de Sampaio; pelo seu ajudante de ordens Antonio José da Silva Paulet [no] anno [de] 1813. ${ }^{139}$ Em ofício de 6 de abril de 1816 ao secretário de Estado dos Negócios Estrangeiros e da Guerra, Marques de Aguiar, o governador Sampaio declarou sua perfeição, "exactidão, justesa", decorrente de "observações e trabalhos trigonométricos". ${ }^{140}$ Ainda em 1816, o governador ordenou a execução de carta geográfica de toda a capitania, e não apenas da costa. A Carta Marítima e Geographica da Capitania do Ceará levantada por ordem do Gov. dor Manoel lgn. co de Sampayo por seu ajudante d'ordens Antonio Joze da S. a Paulet de $1817^{141}$ apresenta os limites territoriais do Ceará, sua rede urbana, topografia e hidrografia. Explicitando as técnicas usadas na elaboração das cartas, Paulet elaborou uma Discripção dos methodos que se empregarão para levantar as cartas hydrographicas do território do Ceará, a qual foi enviada para a Academia Real das Ciências de Lisboa. ${ }^{142}$

Em 1825, Paulet apresentou o projeto da Fortaleza de Nossa Senhora da Assumpção da Capitania do Ceará Grande ao Estado português. Tratava-se, segundo o engenheiro, de um "quadrado fortificado acomodado às circunstâncias do terreno". A construção "bate prefeitam. . $^{\text {te }}$ com duas ordens de fogo cruzado": "o ancoradouro do Porto q' the fica ao Norte e os caminhos q' conduzem, na Praia

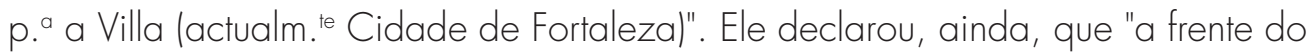
Mar" estava "completamente acabada, e [também] a da parte do Nascente até junto dos Quarteis da tropa, os quaes já existião qdo se formou o Projecto" - daí porque não se achavam "em semetria com os lados da Fortaleza"143 (Figura 5). 144

A fortificação e o quartel foram registrados por Reis Carvalho, pintor da Comissão Científica de Exploração, 145 que correu o Ceará entre 1859 e 1861 . Em fevereiro de 1859, por ocasião da chegada e do desembarque da Comissão Científica, Reis Carvalho aquarelou a Fortaleza de Nossa Senhora da Assumpção na feição mais aproximada que se conhece daquela idealizada pelo engenheiro Silva Paulet. Na aquarela, denominada Vista exterior da cidade de Fortaleza, copiada a bordo do vapor Tocantins, podem-se divisar os dois baluartes e a cortina da fortificação no último terço da imagem. Em cota superior, vê-se o núcleo urbano
137. Castro (2012b, p. 18).

138. Ofício dirigido ao Tenente-Coronel... (1812).

139. A cartografia encontra-se depositada na Mapoteca do Itamarati, Rio de Janeiro.

140. Ofício ao Tenente-Coronel Antonio... (1816). Cf. Jucá Neto (2012b).

141. A cartografia encontra-se depositada no Gabinete de Estudos Arqueológicos de Engenharia Militar (Lisboa).

142. A notícia sobre o envio da Discripção dos methodos... encontra-se em História e Memórias da Academia Real das Sciencias de Lisboa, tomo X, parte II, de 1830. Infelizmente, a documentação propriamente dita ainda não foi localizada no acervo da Academia de Ciências.

143. Castro (2012b, p. 24).

144. As observações quanto ao desenho se encontram no seu verso. Cf. Jucá Neto (2012b).

145. Sobre a Comissão Científica de Exploração, cf. Alemão (2011), Braga (1982), Jucá Neto (2014, 2019) e Kury (2009). 
com a igreja matriz e o quartel, na praça interna do forte. Abaixo, na linha da arrebentação, aparecem as dunas que se espraiavam aos pés dos baluartes. Outro desenho, do mesmo autor, retrata a fachada do quartel, uma edificação assobradada com grande pórtico de acesso ao centro, encimado pelo brasão do Império. À sua direita, assenta-se o baluarte oeste, ainda portando suas canhoneiras, hoje não mais visíveis (Figuras 6 e 7 ).

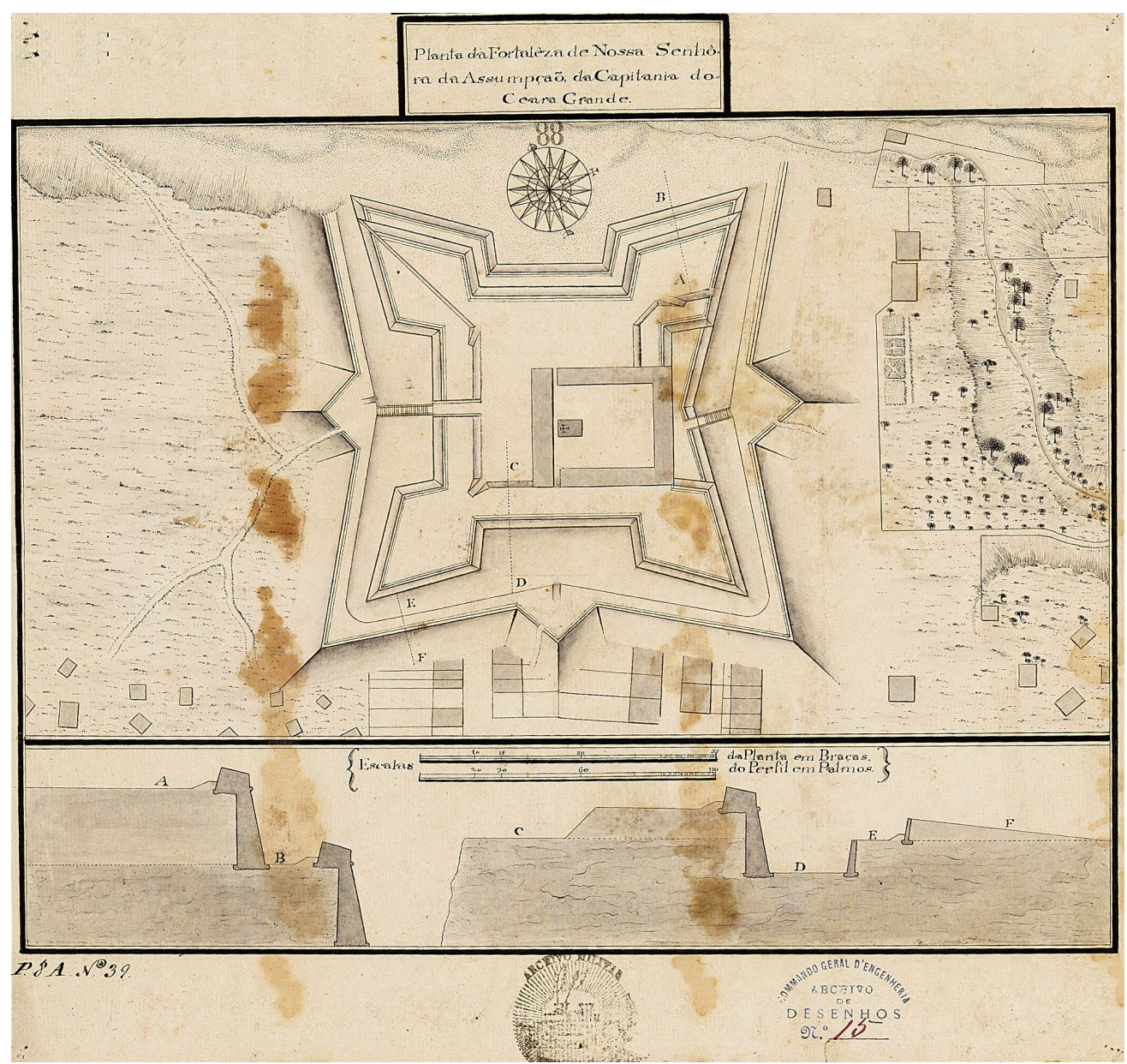

Figura 5 - Engenheiro Antônio José da Silva Paulet. Planta da Fortaleza de Nossa Senhora da Assumpção da Capitania do Ceará Grande. Fonte: Acervo do Gabinete de Estudos Arqueológicos de Engenharia Militar. 


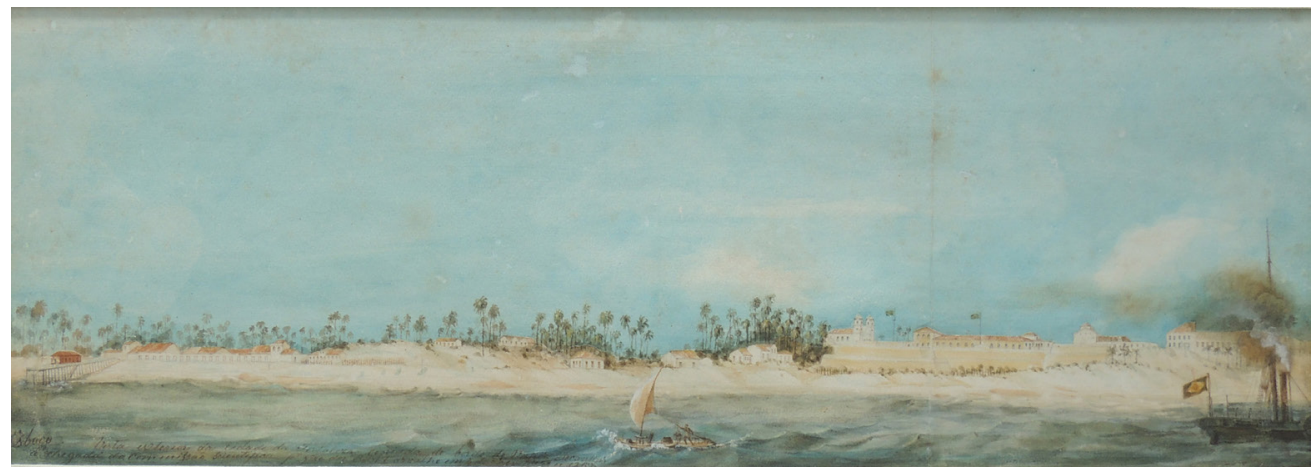

Figura 6 - José dos Reis Carvalho. Esboço Vista exterior da cidade da Fortaleza copiada de bordo do vapor Tocantins. A chegada da Comissão Scientifica por José dos Reis Carvalho em 4 de Fevereiro de 1859, 1859, aquarela, $27 \times 42,5$ cm. Fonte: Coleção do Museu Dom João VI. Reprodução: Paulo Scheuensthul.

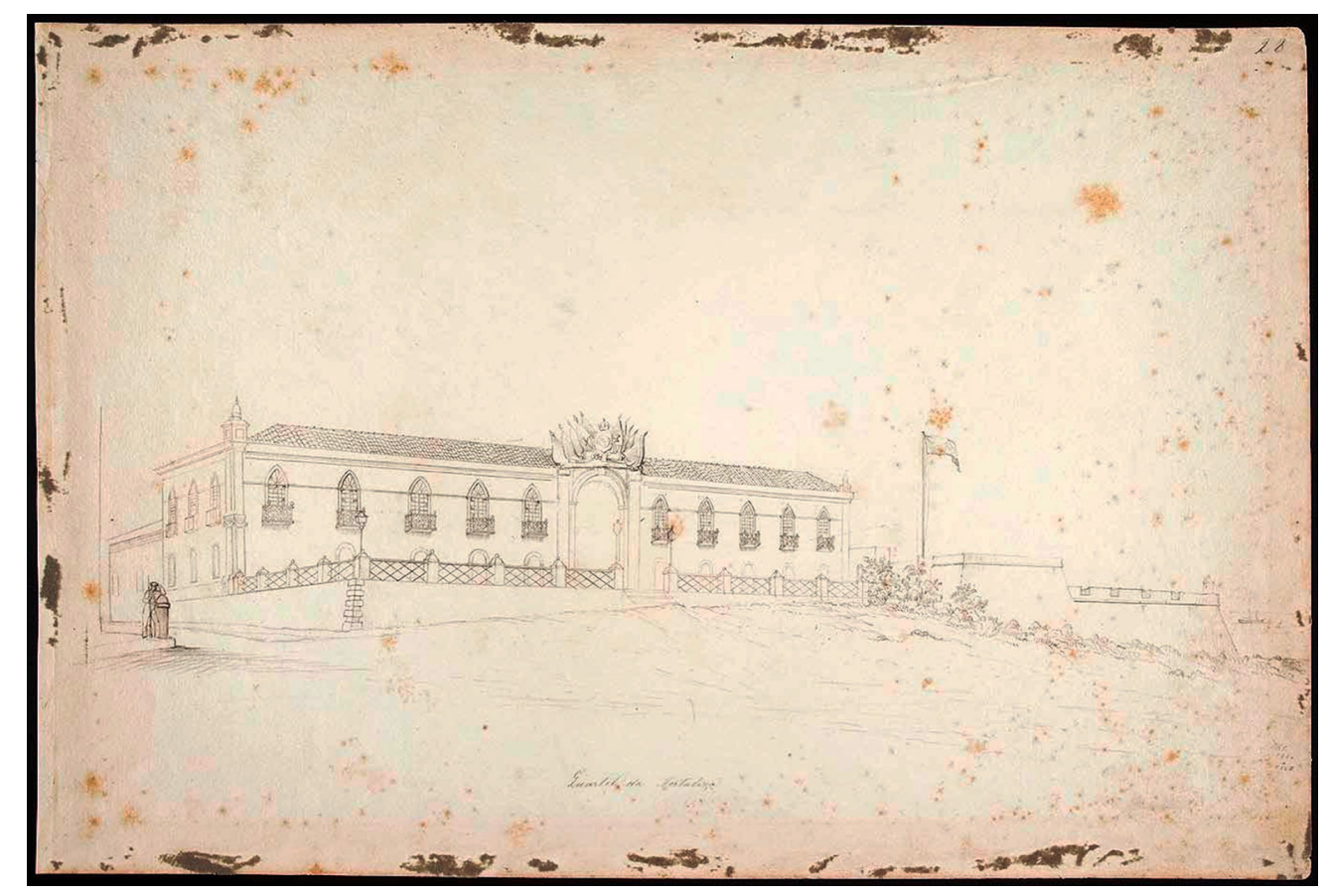

Figura 7 - José dos Reis Carvalho. Quartel da Fortaleza, 1859, crayon, $27 \times 42,5 \mathrm{~cm}$. Fonte: Coleção do Museu Dom João VI. Reprodução: Paulo Scheuensthul.

Importam as considerações de Castro quanto às referências tratadísticas usadas por Paulet quando da elaboração do desenho da fortificação. Segundo o autor, o profissional recorrera aos ensinamentos presentes no livro $\bigcirc$ engenheiro português, de Azevedo Fortes, e optou por um "quadrado, aceito como definição do reparo, sobre o qual desenvolveria o delineamento dos baluartes, dos fossos, das contraescarpas, dos revelins", ou seja, "dos elementos constitutivos das plantas 
146. Castro (2012b, p. 27).

147. Ibid., p. 35.

148. Ibid., p. 35-36.

149. Ibid., p. 36 . e dos perfis da fortificação, traçados segundo as recomendações dos tratadistas". 146 $\bigcirc$ "traçado das faces dos baluartes" obedecia "ao esquema dos triângulos equiláteros, recomendado por Fortes"; contudo, "as linhas que comandavam o traçado dos flancos fugiam discretamente dos ensinamentos do tratadista". ${ }^{147}$

Quanto ao desenho de uma fortificação, Fortes propunha a escolha de um polígono regular ou irregular, afirma Castro. Se regular, teria a forma de "quadrado, pentágono, hexágono ou heptágono". Paulet optou por uma fortificação do "tipo regular, quadrado". Ainda segundo Castro, para Azevedo Fortes, uma "fortificação abaluartada poderia ser grande, mediana e pequena". $\bigcirc$ autor esclarece, em linhas gerais, as recomendações de Fortes quanto ao método de traçado das grandes fortalezas, ou seja, "um sistema baseado nas diagonais do quadrado", com "triângulos equiláteros sobre as diagonais, que marcarão as demigolas, isto é, a nascença das faces dos baluartes", e uma "ligação do ponto extremo dos triângulos (no prolongamento das diagonais) com o meio da cortina oposta, a fim de se definirem as linhas que determinarão os flancos". ${ }^{148}$

No caso das fortificações medianas, o traçado teria dimensões reduzidas. Castro acrescenta que Fortes não explicita as medidas de uma pequena fortificação. Contudo, considerando as dimensões de "108 braças (237,60 metros), estabelecidas por Fortes como medidas dos lados formadores das fortificações medianas", eram superiores às propostas por Paulet. Castro assevera que a "fortaleza da Assunção se enquadraria nos padrões de uma fortificação pequena". 149

A Fortaleza de Nossa Senhora da Assumpção, desenhada com rigor tratadístico por Silva Paulet, foi tombada pelo Instituto do Patrimônio Histórico e Artístico Nacional (Iphan) e incluída no Livro do Tombo Histórico, no Livro do Tombo das Belas Artes e no Livro do Tombo Arqueológico, Etnográfico e Paisagístico, em 4 de janeiro de 2012, respectivamente sob as inscrições de n 601 , 631 e 151 - Processo Administrativo 065 1-T-62.

\section{ARTÍFICES EM TRÂNSITO NOS SERTÕES DO NORTE: A ARTE E A ARQUITETURA RELIGIOSAS NO CEARÁ COLONIAL}

Concomitantemente à esparsa presença de engenheiros militares no Ceará, artífices provenientes de Portugal e de outras Capitanias do Norte percorreram os sertões cearenses. Durante o século XVIII, a iniciativa particular de alguns potentados da terra, criadores de gado ciosos em dar expressão pública às suas pequenas 
fortunas e brios, inaugura, na capitania, um período de construção e multiplicação de pequenas capelas e igrejas e, em consequência disso, de povoados e freguesias.

A incipiente economia do gado, pouco capitalizada, não suscitou grandes investimentos por parte do Estado, o que, por sua vez, não engendrou um mercado que atraísse e absorvesse a técnica especializada de engenheiros, salvo raríssimas exceções de iniciativa da administração real. O fazer das obras atraiv e absorveu uma cadeia produtiva de arquitetura orquestrada pela práxis dos artífices, fossem oficiais de pedreiro, pintores ou escultores. ${ }^{150}$

No lastro do processo de migração, esses profissionais circularam nas Capitanias do Norte, idealizando e construindo edifícios civis e religiosos, encetando o papel de importantes "agentes da cultura arquitetônica"151 dos sertões. Muitos provieram da região do Minho, no Norte de Portugal, e suas habilidades eram múltiplas. Smith, por exemplo, expõe largo panorama de produtos manufaturados pelos artífices portugueses presente no regimento do Senado da Câmara de Lisboa de 1768. ${ }^{152}$ Podiam executar toda a "talha em qualquer obra que com a dita talha for guarnecida" e fazer "Capelas de lgrejas, Sacrarios, Tronos, Maquinetas, Castiçães, Tocheiros, Siriaes, Piramidas, Pulpitos, Varandas de Orgaons, Paines de Igreja, Cancellos", de "madeiraz brancaz, que se Costumao dourar, ou praticar, ou pintar, ou de outras quaisquer madeiras, que Seus donos as quiserem". Ainda segundo Smith, durante o século XVIII, "como nunca antes, a talha se tornou um elemento indispensável nos interiores das igrejas portuguesas". 153 Tais mestres de ofício lograram grande distinção, chegando a influenciar nas plantas e em sistemas de cobertura de templos religiosos. Os entalhadores lusitanos adaptaram "sucessivamente ao seu ofício grandiosos esquemas de arquitetura barroca e rococó sem paralelo na arte dos outros países".

Ainda que se tratasse de profissionais autônomos, independentes do régulo da Coroa, para desempenhar suas funções eram submetidos a testes baseados nos regimentos camarários de Portugal, os quais davam ideia do quão versáteis eram suas atribuições, com nítidos sombreamentos entre arquitetura, escultura e pintura. Isso fica bastante claro quando se observam os exames aplicados aos sambladores, entalhadores e imaginários a partir do regimento de 31 de dezembro de 1549. ${ }^{154}$ Smith acrescenta que nos "exames estabelecidos nos regimentos havia pouquíssima diferença entre ensambladores e entalhadores, ambos construtores de retábulos". Eram "obrigados ao conhecimento das obras arquitetônicas e à capacidade de entalhar padrões decorativos previamente estabelecidos". 155 Vale ressaltar a distinção, no período, da Escola do Norte de Portugal, lugar de origem de alguns artífices que transitaram pelo Ceará, "com suas poderosas composições de decoração transbordante, que tanto influenciaram" o Brasil. ${ }^{156}$
150. Bueno (2012, p. 336).

151. Tomamos de empréstimo o termo cunhado por André Dangelo (op. cit.) em sua tese de doutoramento denominada A cultura arquitetônica em Minas Gerais e seus antecedentes em Portugal e na Europa: arquitetos, mestres de obras e construtores e o trânsito de cultura na produção da arquitetura religiosa nas Minas Gerais setecentistas.

152. Smith (1962, p. 12).

153. Ibid., p. 8 .

154. Ibid., p. 11.

155. Ibid., loc. cit. 156. Ibid., p. 8. 
157. O referido artífice, anos depois, estabeleceu-se no Ceará.

158. Consulta do Conselho Ultramarino... (1736).

159. Relação da Freguesia de S. João... (1757).

160. Ibid.
Orgumento da circulação e relevância dos mestres de ofício nas Capitanias do Norte fica patenteado em parecer, do ano de 1733, do provedor da Fazenda da Bahia ao Conselho Ultramarino. Ele sugere entregar a obra real de uma igreja matriz a um oficial de pedreiro e entalhador, ${ }^{157}$ diante da ausência de engenheiros que quisessem adentrar os sertões no exercício da profissão. ${ }^{158}$ Dada a inexistência - em Jeremoabo, sertões da Bahia - de "Igrejas, ou capelas em q. se poderem administrar os Sacramentos com a descencia devida"; diante do estado de ruína da ermida existente de "pedra e barro"; considerando a grande distância e sendo ali "parte quase deserta", em decorrência da dificuldade de acesso em "clima pouco saudável", por "atravessar agrestíssimos caminhos"; argumentando não haver pessoas que "se quisessem sujeitar a hir fabricar essas obras e ordinariamente as fazem alguns oficiais residentes nos mesmos Certões pelos riscos que levam"; o provedor da Fazenda requereu "esmola de quatro mil cruzados, quatrocentos mil no primeyro anno e duzentos mil em cada hum dos seguintes the se refazerem, para com esta ajuda de custo se ajudarem para fabricar a lgreja Matriz". Ao final do referido contrato, "a obra estava de todo acabada, e posta na sua última perfeição, segundo os pedidos da architetura e planta que fora mostrada". 159

Além de explicitar a circulação de artífices nos longínquos sertões, suprindo demandas edilícias reprimidas em sua ałuação pragmática, com seus riscos em punho, o documento aponta algum contato, ou mesmo uma relação de complementariedade, entre artífices e funcionários reais - estes detentores de algum conhecimento técnico, o que os tornava responsáveis pela vistoria da obra. Neste caso, a fonte não nos permite afirmar se tais funcionários eram engenheiros de formação acadêmica. No que se refere às obras reais, geralmente manejadas por engenheiros, a documentação revela situações em que a administração relativizava o controle da execução e o uso dos recursos em função de vicissitudes geográficas, delegando-os a artífices, desde que de "fiança idônea a mostrar como os tem gasto em obra na fábrica della". Na esteira desse controle parcial exercido pela Coroa sobre a referida obra da igreja de Jeremoabo, contratada com o artífice Araújo Portugal, é possível aduzir sua interação com o funcionário da Coroa por ocasião das vistorias, quando o pároco afirma existir "hum termo de vistoria, que apresentou, de que a obra estava de todo acabada, [...] e ainda com mais perfeiçoens de que mandava a mesma planta [...]. São formaes palavras do termo de vistoria, que na Caza da Fazenda Real se acha". 160

A ação de pedreiros, pintores ou escultores e suas origens, percursos e campos de atuação endossam fluxos migratórios e revelam uma complexa e articulada rede de circulação de ideias, imagens e relações entre esses artífices em fluido movimento, hibridizando-se ao interligar longínquos pontos do Império ultramarino português: Portugal, Bahia, Pernambuco, Paraíba, Rio Grande do Norte e Ceará. 
Não se registrou, no Ceará, o implemento de grandes estruturas em talha a recobrir integralmente espaços arquitetônicos, tais como os exemplares de pleno horror vacui vistos nos grandes centros do litoral. Sua existência esteve relacionada, em maior ou menor escala, às estruturas retabulares, quase sempre contidas em capelas-mores, com aplicações "epidérmicas e episódicas" de elementos artísticos transculturados do léxico barroco e rococó. ${ }^{161}$ llustramos essa assertiva com os trabalhos em talha das igrejas de São Francisco, em Canindé, e de Nossa Senhora do Rosário, em Aracati (Figuras 8 e 9).

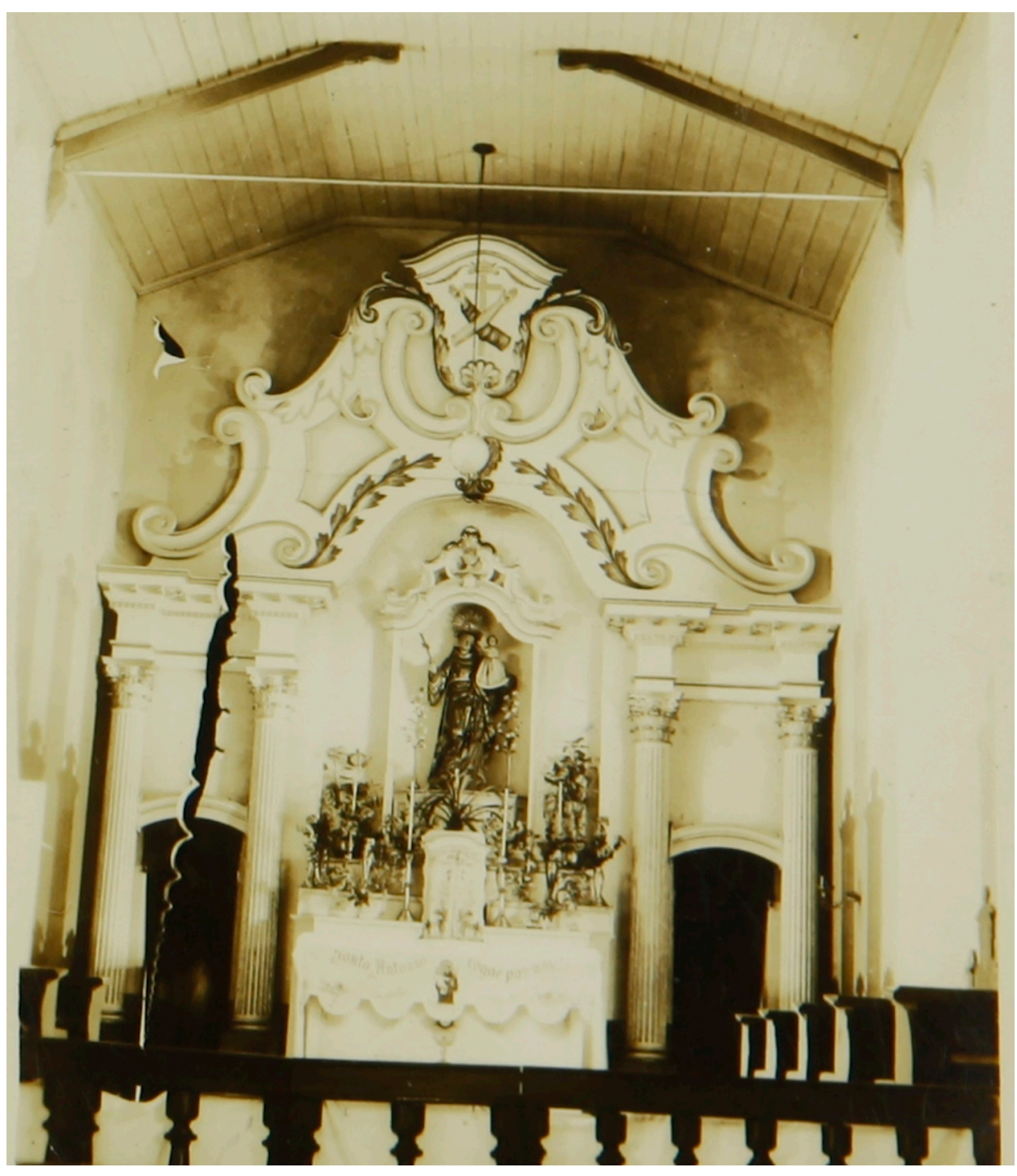

Figura 8 - Fragmento do retábulo da antiga lgreja de São Francisco de Canindé, Ceará. Fonte: Acervo do Arquivo Noronha Santos, Iphan. Foto: João José Rescala, 1941. 


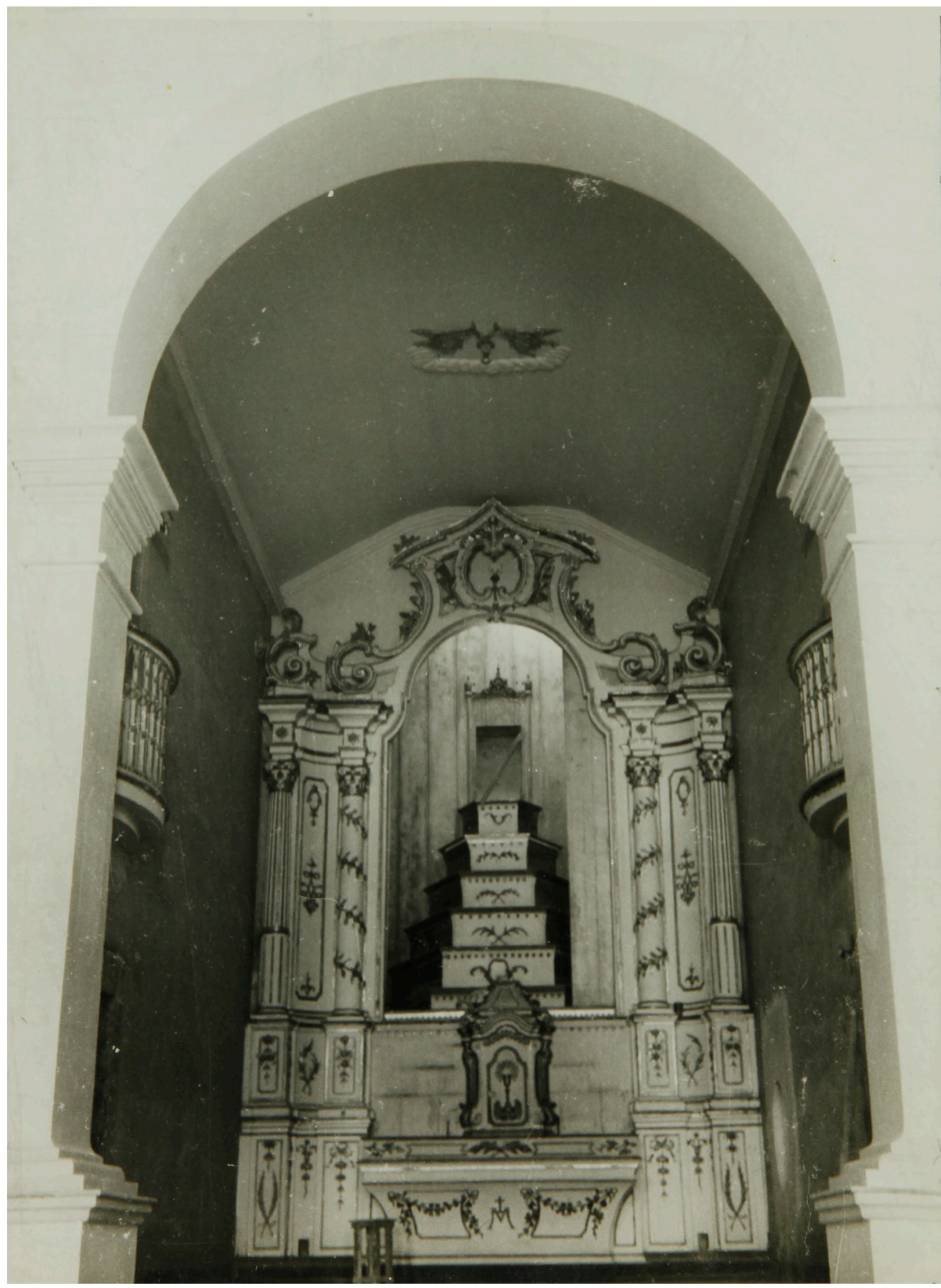

Figura 9 - Retábulo da Igreja de Nossa Senhora do Rosário, de Aracati, Ceará. Fonte: Acervo do Arquivo Noronha Santos, Iphan. Foto: João José Rescala, 1941. 


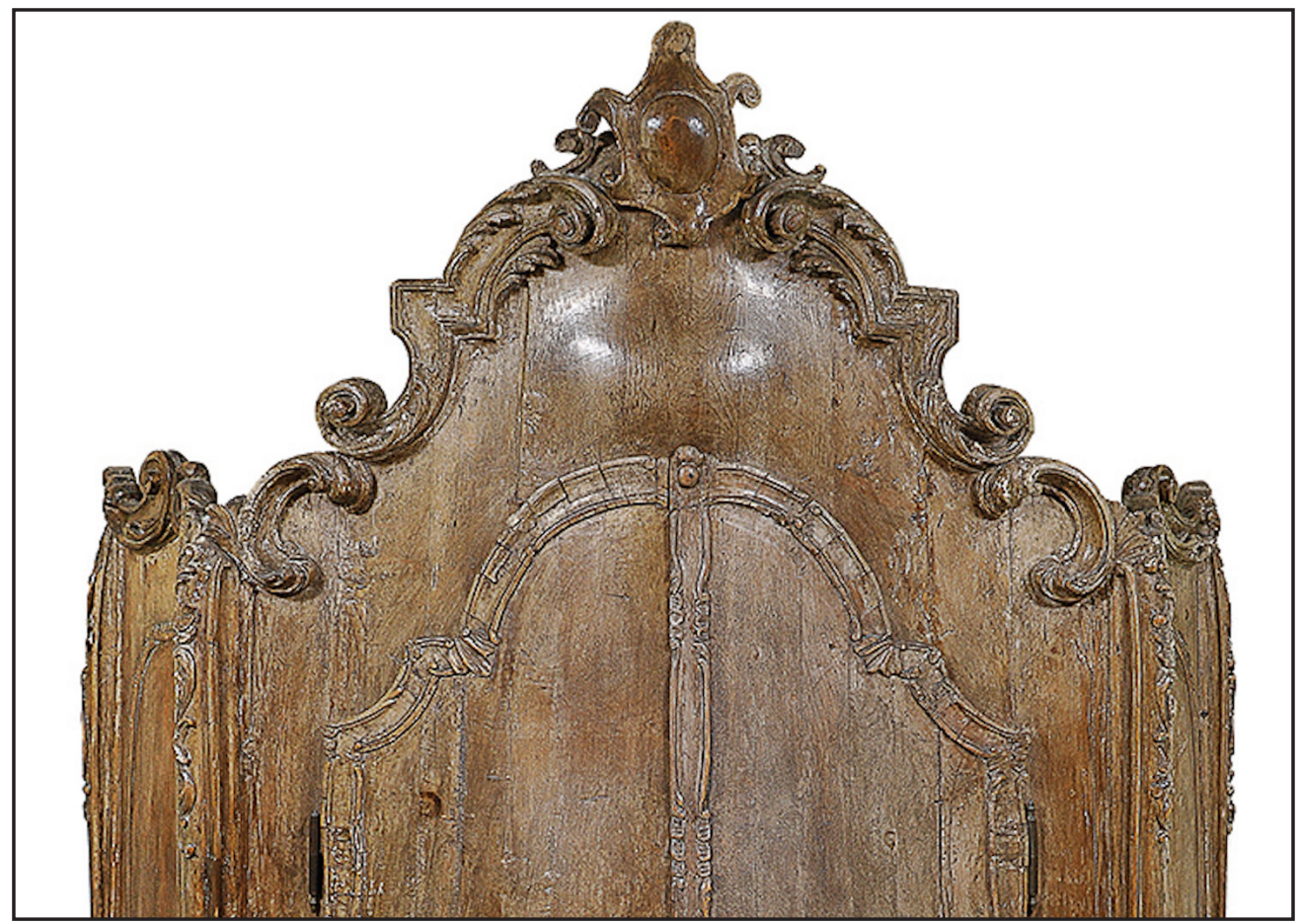

Figura 10 - Detalhe do frontão de oratório doméstico, Rio de Janeiro. Foto: Ramiro Teles, 2016.

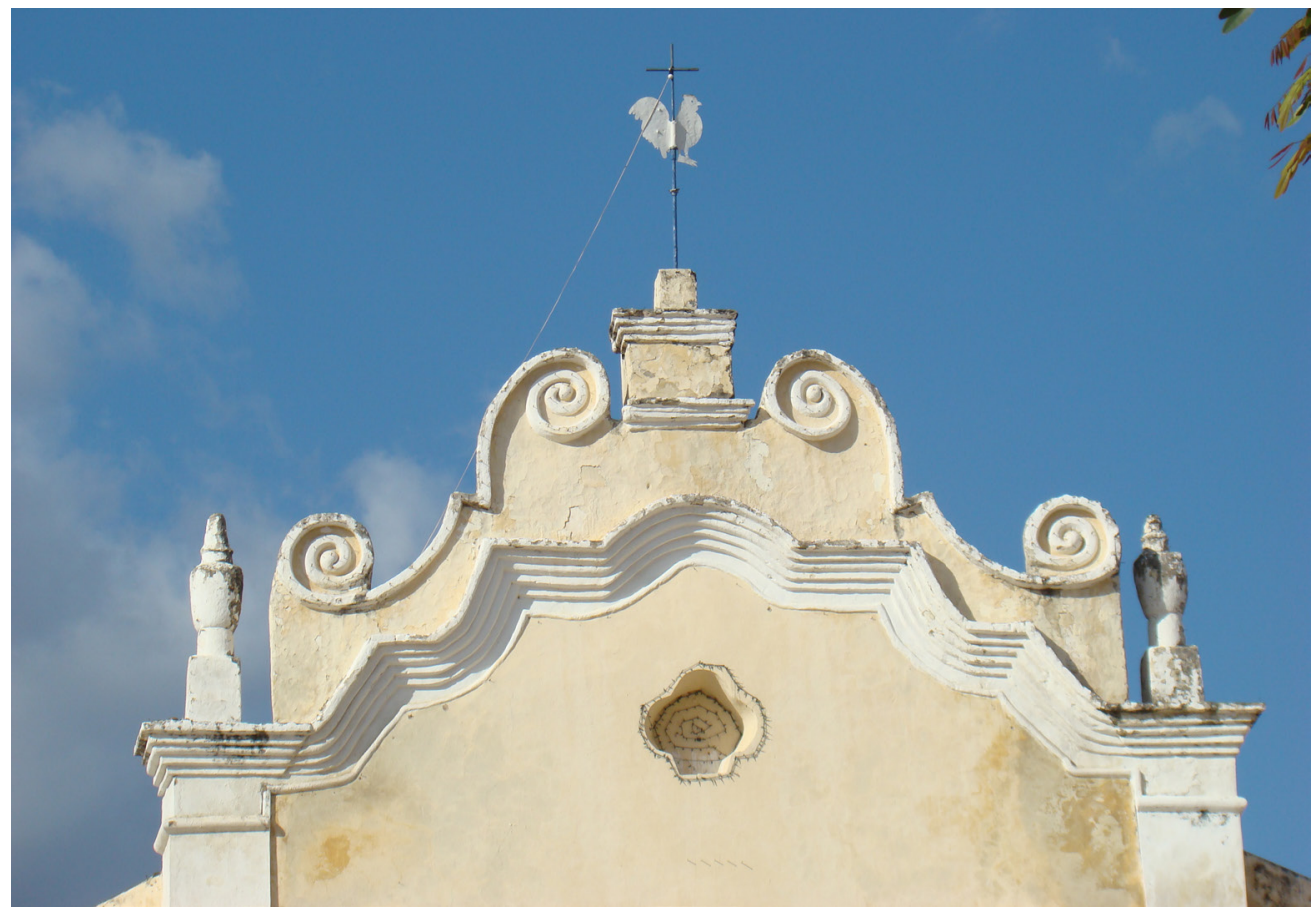

Figura 11 - Frontão da Igreja de Nossa Senhora da Purificação, de Saboeiro, Ceará. Foto: Ramiro Teles, 2015. 
Esses elementos das artes decorativas portáteis - retábulos, oratórios, sacrários, relicários, sanefas, ourivesaria, entre outros -, ora importados da Bahia e de Pernambuco, ora de Portugal, continham nítidas mensagens do repertório estético vigente. Pela natureza móvel de seus suportes, converter-se-iam em eficientes difusores de uma cultura visual, dada a ausência de profissionais acadêmicos e desenhos técnicos. Seriam repositórios para as composições arquitetônicas reinterpretadas e ajustadas à escala apropriada dos edifícios, como visto nas volutas do frontão e nos contornos de porta de oratório doméstico (Figura 10) que, nitidamente, se repetem nas linhas do frontão e cornija da lgreja de Nossa Senhora da Purificação de Saboeiro, edificada por volta de 1780 (Figura 11).

Figura 12 - Oratório ermida oriundo da Ribeira dos Icós (c. 1770). Foto: Ramiro Teles, 2015.

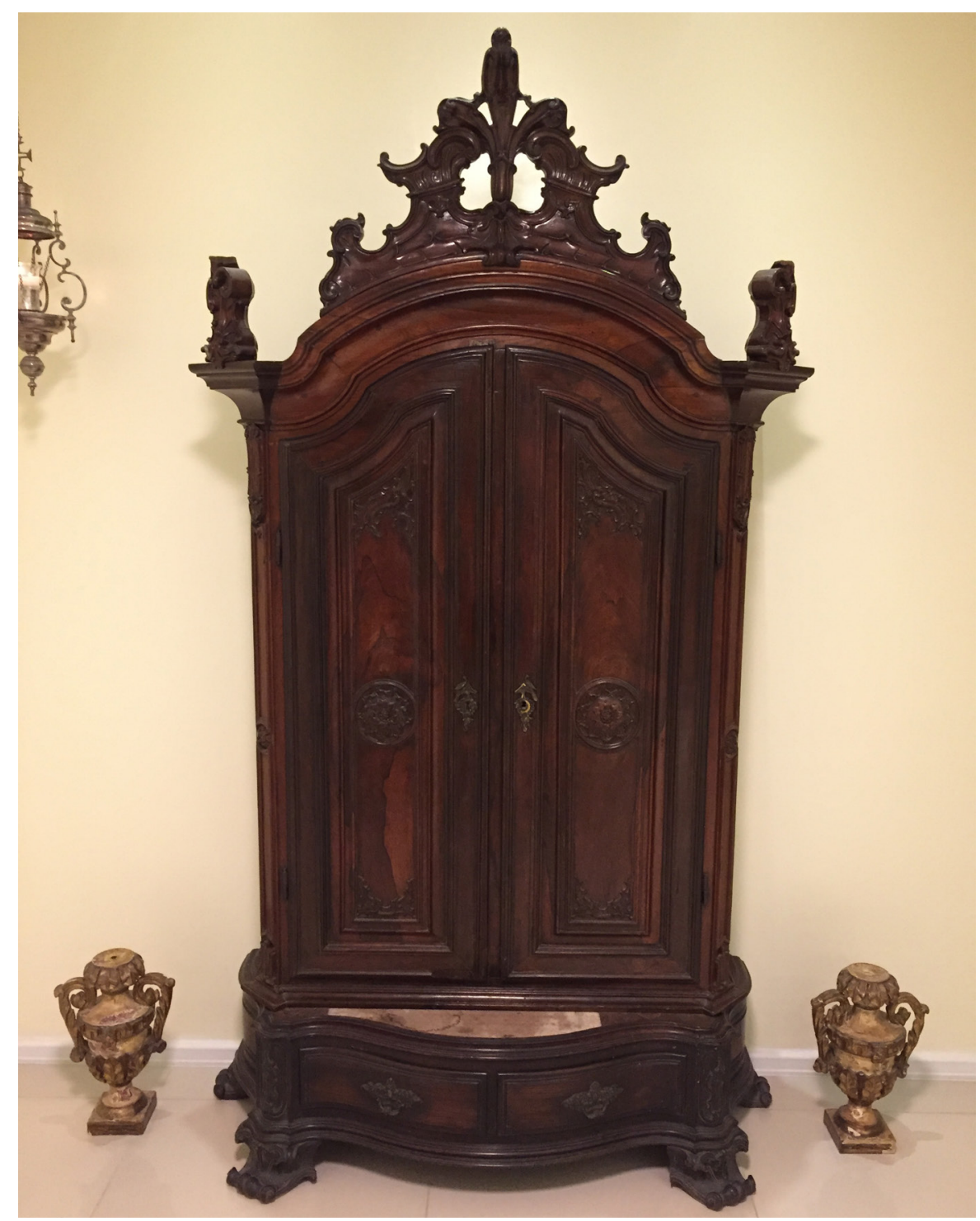




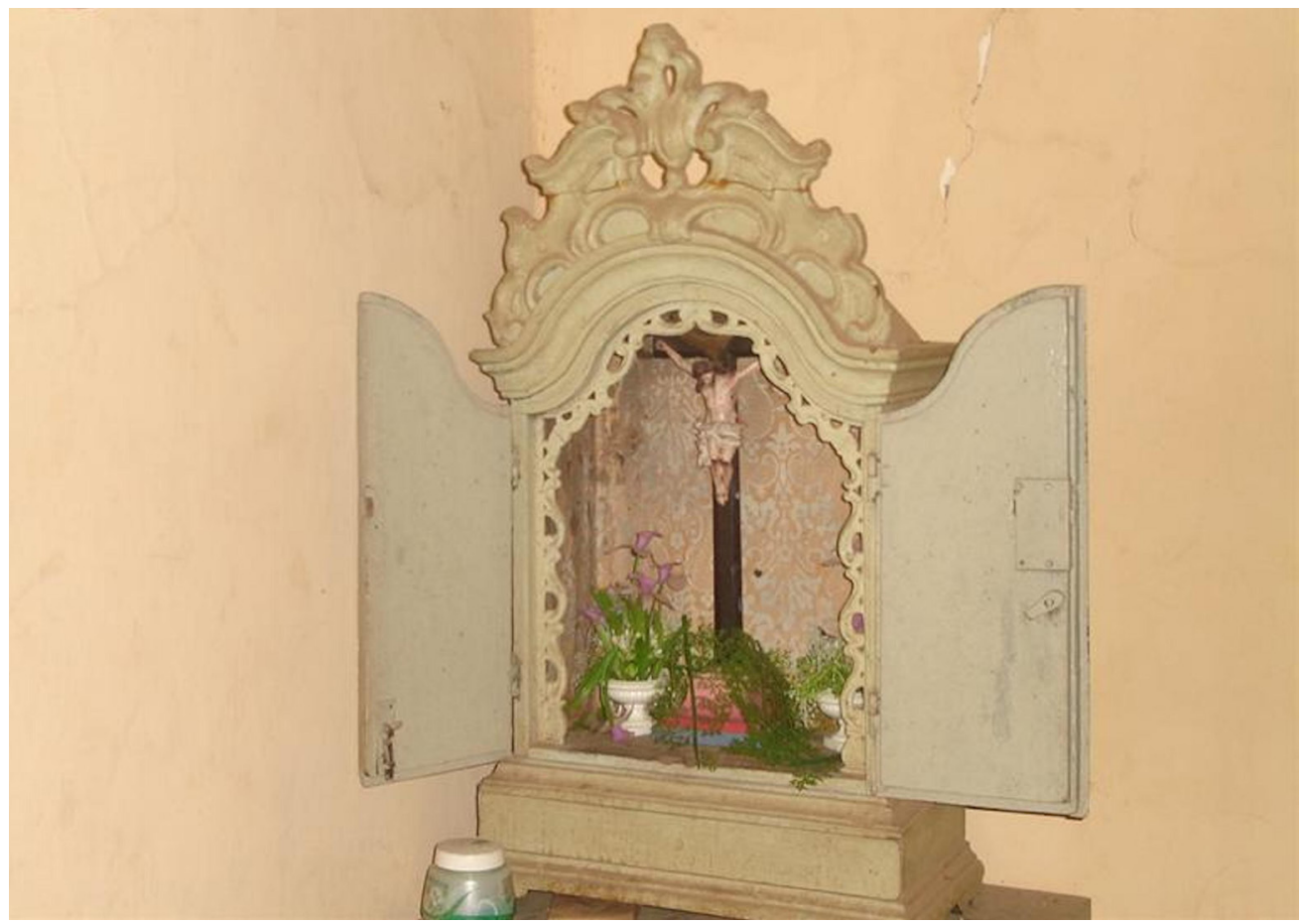

Figura 13 - Oratório de alcova encontrado no Cariri (séc. XVIII). Foto: Ramiro Teles, 2015.

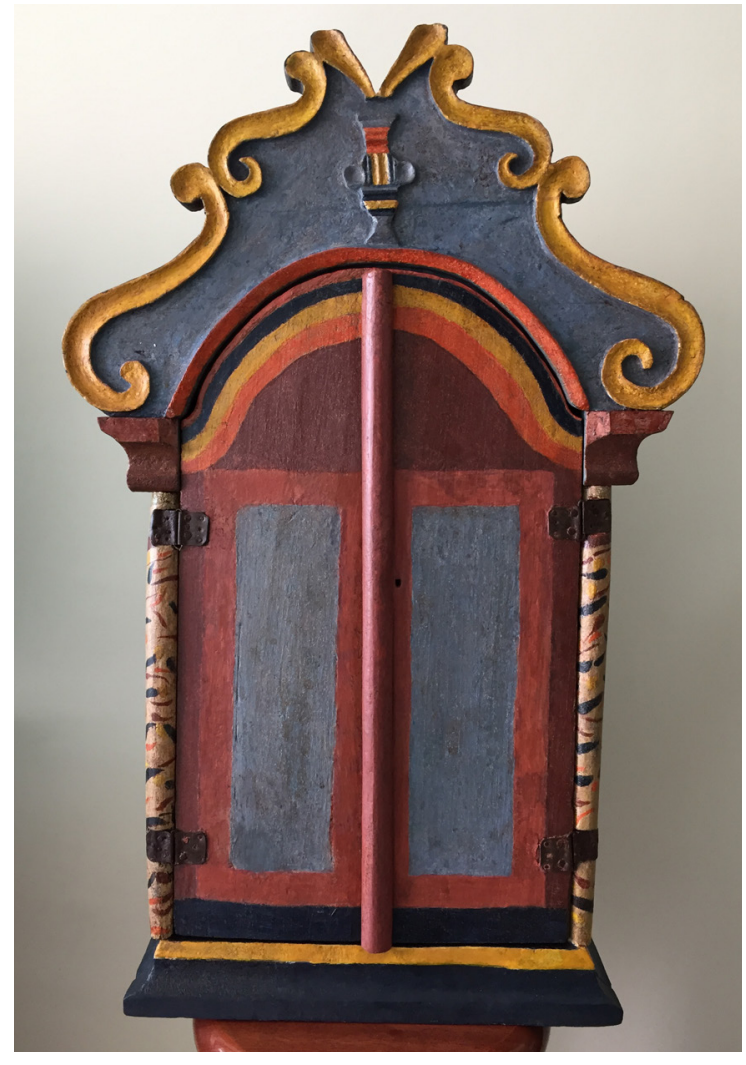

Figura 14 - Oratório doméstico vindo da Ribeira do Jaguaribe (séc. XVIII). Foto: Ramiro Teles, 2015. 
162. Beserra (2018).

163. Sobre a simplicidade volumétrica e construtiva da arquitetura cearense, mais especificamente das casas de fazenda dos sertões do Ceará, cf. Jucá Neto (2019).

Figura 15 - Vinheta capitular do Missale Romanum. Antuerpiae: Architypographia Plantiniana, MDCCXXXVIII. Fonte: Arquivo do Museu de Arte Sacra de Aquiraz. Foto: Alexandre Jacó, 2019.
Esses objetos circulavam pelos sertões da capitania ora em versões mais eruditas, como no oratório ermida oriundo da Ribeira dos Icós (Figura 12) e no oratório de alcova encontrado no Cariri (Figura 13), ora em desenhos mais simplificados, como em oratório doméstico existente na Ribeira do Jaguaribe (Figura 14), mas sempre impregnados do pendor plástico barroco e rococó, revelado nas suas composições e nos arqueados, espirais e enrolados de seus entalhes.

Também gravuras flamencas e portuguesas, presentes em missais e outras obras literárias, correram os sertões levadas por religiosos. Frontões, pórticos serlianos, pilastras, entablamentos, volutas, rocailles, coruchéus, mísulas e estípites estavam ao alcance das mãos inventivas dos arifífices, transmutados por seus sentidos, filtrados pelas mensagens e pelo referencial imagético sub-reptício que traziam de pretérita lida no ofício, valendo-se das possibilidades técnico-econômicas oferecidas pelo meio. ${ }^{162}$ Diversos missais dos séculos XVII e XVIII, do acervo da lgreja Matriz de Aquiraz, apresentam elementos tipográficos ornamentais à guisa de arquiteturas, tal como uma das vinhetas capitulares de exemplar de 1738 impresso na Antuérpia (Figura 15).

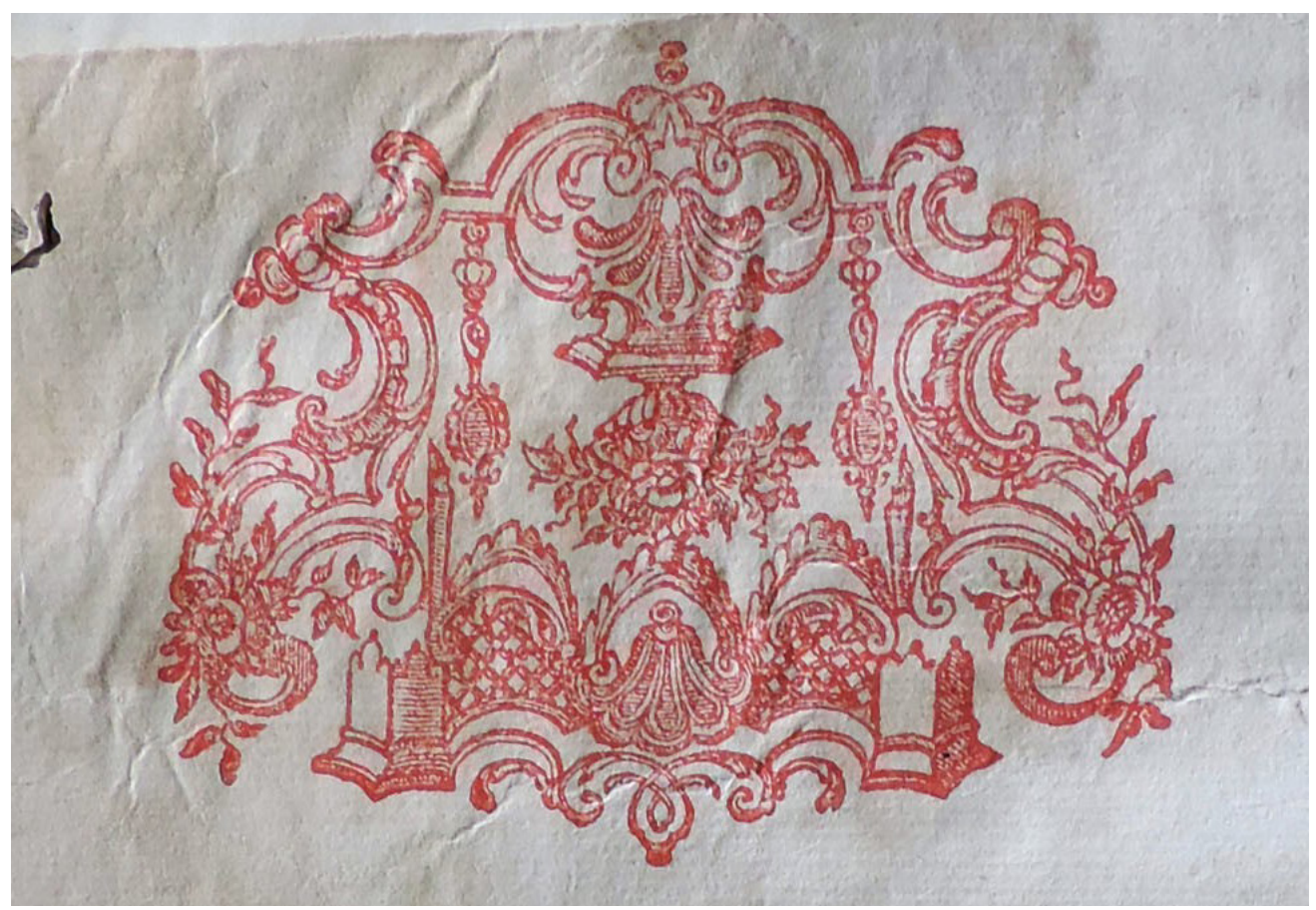

Barroso assevera que a "arte do Ciclo do Gado é mais humilde", sem grandes arroubos formais. ${ }^{163}$ Sua arquitetura se faz pela "falta da pedra de obragem apropriada, em simples alvenaria, na qual se executa uma ornamentação própria", sem "escultura, nem cinzeladuras, nem obra de talha, nem ouros, nem lioz, nem mármore, nem azulejos". $\bigcirc$ adorno resultava das linhas de "artistas anônimos", por "combinação 
ingênua das curvas e dos ornatos retilíneos, os efeitos decorativos" de um "espírito barroco". Para Barroso, onde "ainda não foram desfiguradas, as construções de pedra e cal, ornamentadas com volutas e arrecadas de simples reboco, se mostram como documentos vivos dum passado, esse absolutamente brasileiro", 164 tal como se vê nas fachadas das igrejas do Rosário dos Pretos, de Quixeramobim, ou de Nossa Senhora da Purificação, de Saboeiro (Figuras 16 e 17).
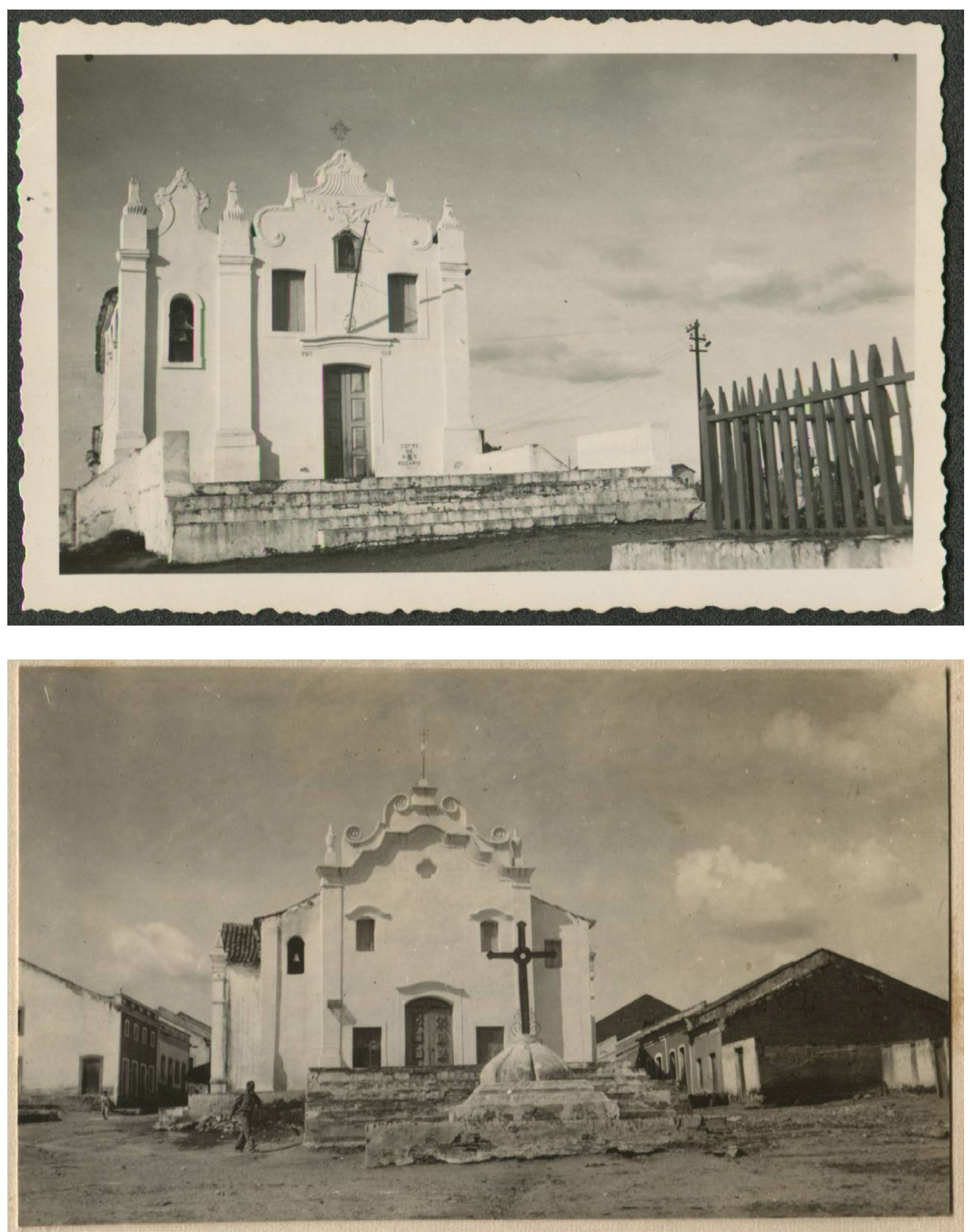

164. Barroso (1948, p. 34)

Figura 16 - Igreja de Nossa Senhora do Rosário dos Pretos, de Quixeramobim, Ceará. Fonte: Acervo do Arquivo Noronha Santos, Iphan. Foto: João José Rescala, 1941.

Figura 17 - Igreja de Nossa Senhora da Purificação, de Saboeiro, Ceará. Fonte: Acervo do Arquivo Noronha Santos, Iphan. Foto: João José Rescala, 1941. 
Figura 18 - Retábulo da Igreja de Nossa Senhora do Rosário, de Russas, Ceará (1790). Foto: Ramiro Teles, 2018.
Ainda que integrados de forma esparsa nas edificações e sem autoria definida, objetos artísticos de inspiração barroca e rococó revelam vigoroso trânsito de mensagens plásticas e de mercadorias entre os sertões e outros centros do ultramar português, sendo possível identificar paralelos entre vocábulos arquitetônicos e elementos decorativos dos quais foram transculturados.

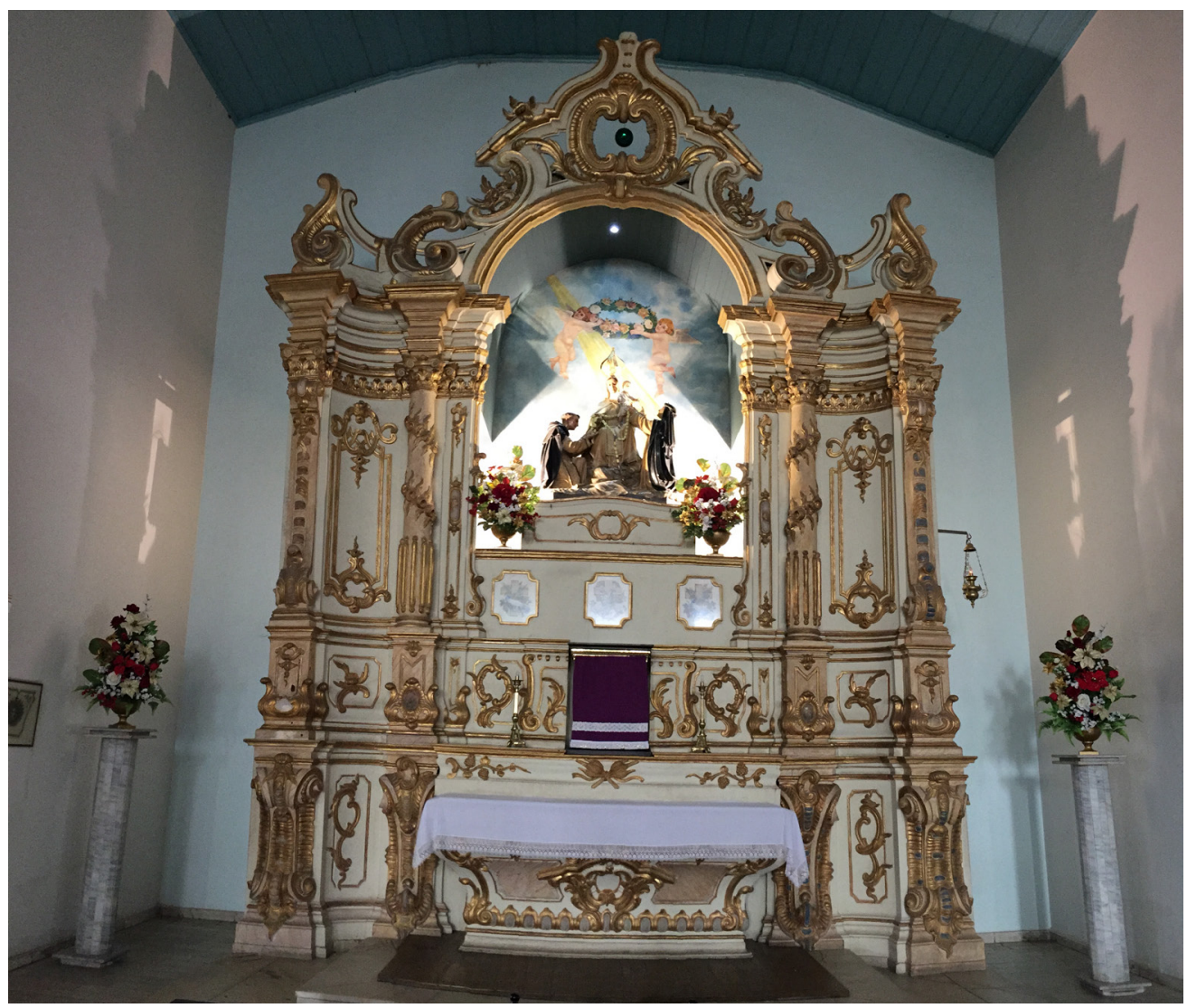

Trazemos à pauta o esplendor do retábulo da Igreja Matriz de Nossa Senhora do Rosário das Russas, obra rococó importada de Pernambuco em 1790 (Figura 18) que guarda grandes semelhanças com o retábulo de São Sebastião de Olinda e com o retábulo de São Bento, da mesma cidade, inspirados naquele do Mosteiro de Tibães, em Braga; os remanescentes de talha da Matriz de Icó; os sacrários das igrejas da Assunção, de Viçosa, Ceará (Figura 19); dos Prazeres, de Aracati; de São José de Ribamar, de Aquiraz; de Nossa Senhora da Palma, de Baturité; de São José de Granja, que guarda muita similaridade com o púlpito da Capela da Jaqueira, em Recife; de Nossa Senhora do Carmo, de Jucás (Figura 20); de São José, de Missão Velha; e de Nossa Senhora da Purificação, de Saboeiro; as portas da Matriz de Nossa Senhora da Penha, do Crato, com suas rocalhas rococó entalhadas nas 
almofadas; além dos trabalhos rococós em lioz português existentes nas portadas da Matriz de Sobral (Figura 21), ou os lavabos e pias da mesma igreja e da de São José, de Granja (Figuras 22 e 23), entre outros exemplos.
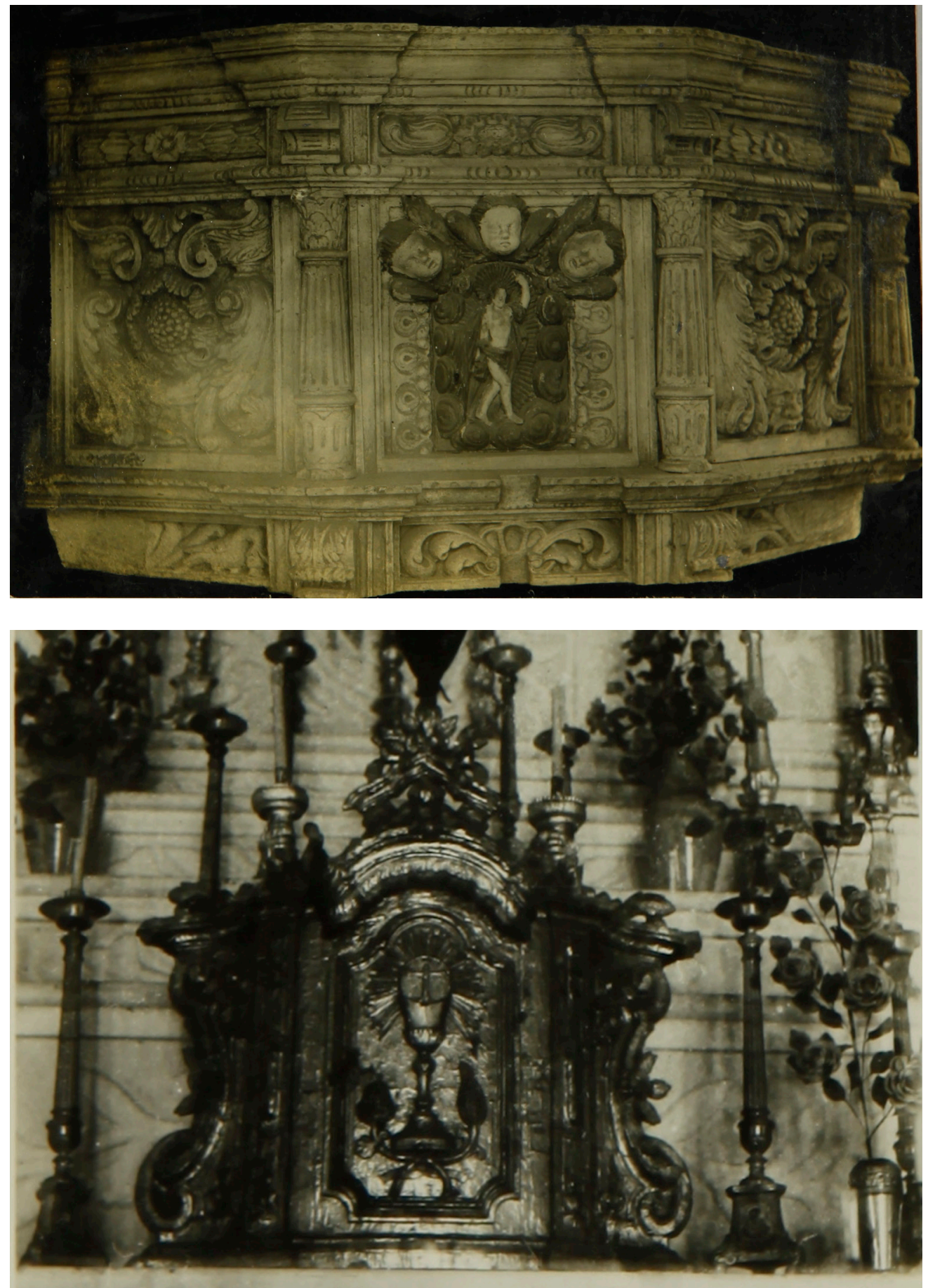

Figura 19 - Antigo sacrário da lgreja de Nossa Senhora da Assunção, de Viçosa, Ceará (c. 1730), hoje no Museu Dom José, em Sobral, Ceará. Fonte: Acervo do Arquivo Noronha Santos, Iphan. Foto: João José Rescala, 1941.

Figura 20 - Antigo sacrário da lgreja de Nossa Senhora do Carmo, de Jucás, Ceará (c. 1770). Fonte: Acervo do Arquivo Noronha Santos, Iphan. Foto: João José Rescala, 1941. 
Figura 21 - Detalhe das portadas em lioz entalhadas com ornamentação rococó existentes na lgreja de Nossa Senhora da Conceição, de Sobral, Ceará (séc. XVIIII). Foto: Gerson Amaral, 2018.

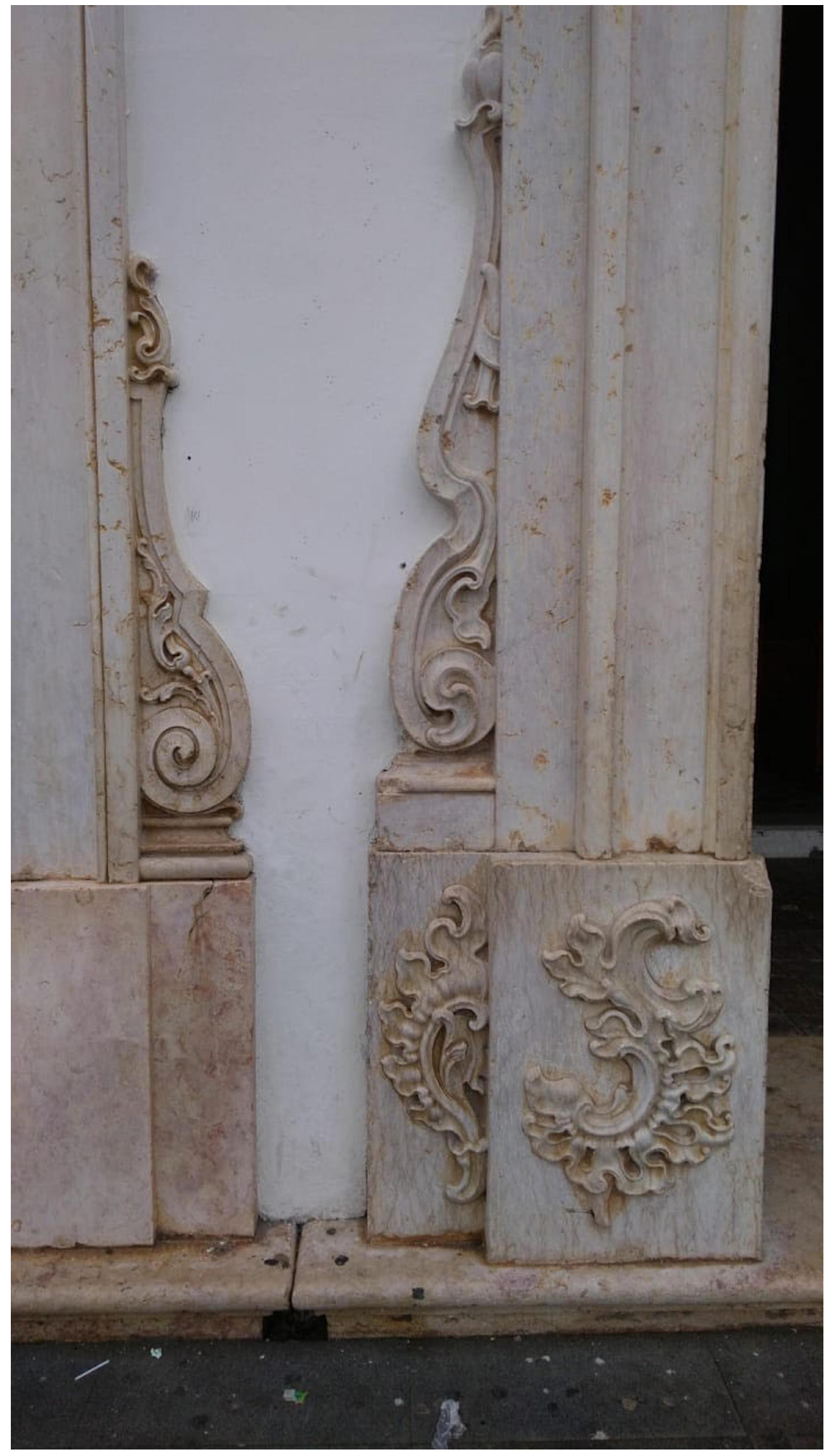

ANAIS DO MUSEU PAULISTA - vol. 29, 2021. 


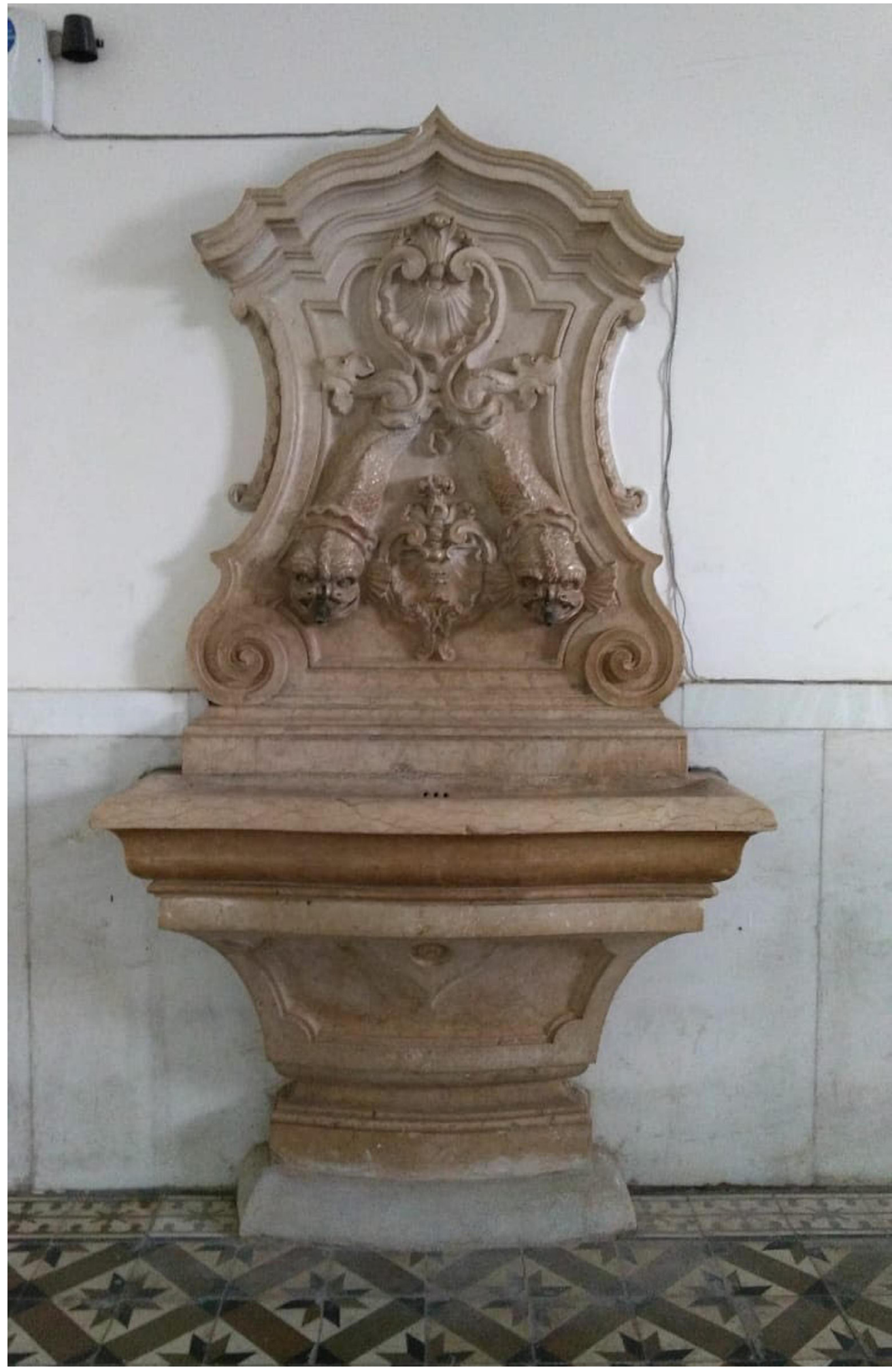

Figura 22 - Lavabo em lioz da lgreja de Nossa Senhora da Conceição, de Sobral, Ceará (séc. XVIIII). Foto: Gerson Amaral, 2018. 
165. Destaca-se o trabalho de Pinheiro (2016) que, investigando Processos Inquisitoriais presentes no Arquivo da Torre do Tombo, trouxe à luz a trajetória de vida e profissional dos artífices portugueses Antônio Correia de Araújo Portugal e Antônio Mendes da Cunha, de quem aqui trataremos. $\mathrm{O}$ referido trabalho forneceu importante aporte metodológico na estruturação de nossa análise, tanto no que diz respeito ao tratamento das referidas fontes primárias sob um viés historiográfico cronológico da mobilidade destes personagens, como ao propor a espacialização, em mapas, do seu trajeto e circularidade.

Figura 23 - Lavabo em lioz da Igreja de São José, de Granja, Ceará (séc. XVIII). Fonte: Acervo do Arquivo Noronha Santos, Iphan. Foto: João José Rescala, 1941.

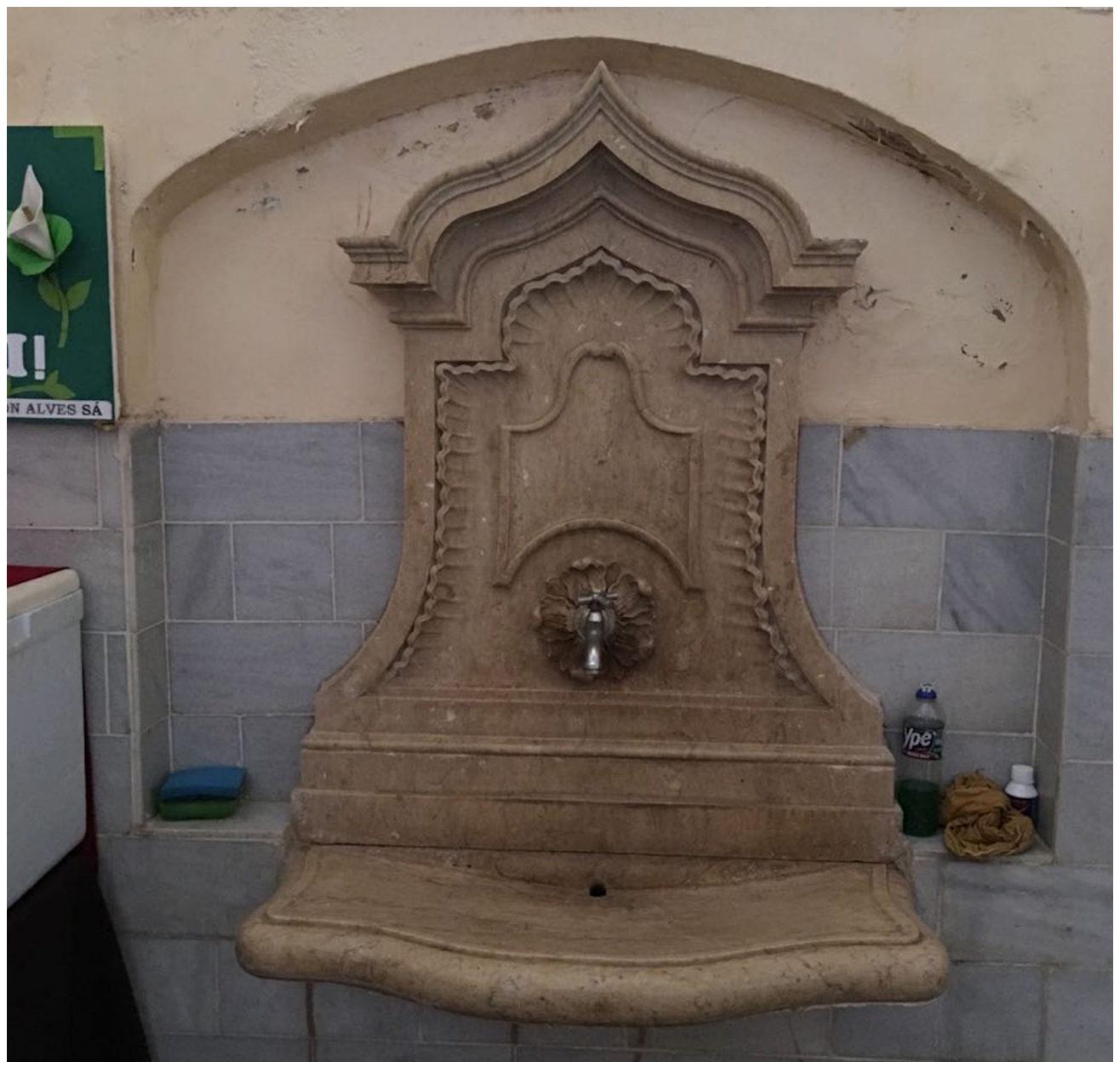

À parte o anonimato das obras e o desconhecimento da proveniência exata dos artífices e das referências decorativas e arquitetônicas, pesquisas recentes com fontes pouco usuais e até então inéditas - arquivos paroquiais e documentação indiciária - têm revelado o nome e a trajetória de alguns desses importantes agentes da cultura artística dos sertões do Norte. ${ }^{165}$

\section{O oficial entalhador - e construtor - Antônio Correia de Araújo Portugal}

Uma rara e das mais antigas referências a noticiar e valorar obras de talha oriundas do período colonial no Ceará é a nota de João José Rescala - representante do Serviço do Patrimônio Histórico e Artístico Nacional (Sphan) que percorreu os sertões cearenses nos primeiros anos da década de 1940 - sobre o retábulo da Igreja Matriz de Nossa Senhora da Expectação de Icó. Rescala sugere que o 
antigo retábulo é da lavra de Antônio Correia de Araújo Portugal, entalhador português que esteve no lcó em 1765 e, anos antes, executara a igreja de Jeremoabo. Do conjunto, conservava-se "ainda um primoroso e antiquíssimo sacrário todo dourado, assim como castiçaes de madeira de vários tipos e tamanhos". ${ }^{166}$

Em Matrizes e capelas do Ceará: circularidade e conexões atlânticas: arquitetura e artífices entre os sertões do Norte e Portugal (1700-1820), Ramiro Teles Beserra confirma a suposição de Rescala sobre a autoria do retábulo analisando os autos de processo de acusação contra Antônio Correia de Araújo Portugal. ${ }^{167} \bigcirc$ artista, que se dedicara ao ofício de construir e embelezar edifícios católicos, fora processado pela própria lgreja e condenado pelo Tribunal do Santo Ofício pelo crime de bigamia. ${ }^{168}$

Araújo Portugal nasceu em fins do século XVII, na pequena aldeia de São Miguel de Seide, comarca de Viana do Castelo, pertencente ao Arcebispado de Braga (Figura 24). No depoimento prestado no Tribunal do Santo Ofício, o artista qualificava-se como "offecial de entalhador e de fazer retabolos", 169 outras vezes como "offecial imaginário"170 - profissão que o distinguia dentre os numerosos profissionais que compunham a categoria de oficiais mecânicos. $\bigcirc$ entalhador bracarense era integrante do contingente de oficiais entalhadores da Escola do Norte de Portugal. Em 1720, seguiu para a freguesia de Santa Marinha de Chorense, "aonde tinha hido por ocasião de trabalhar pelo seo officio"171 na "factura do retábulo para a Capella Mor [...] daquela igreja". 172

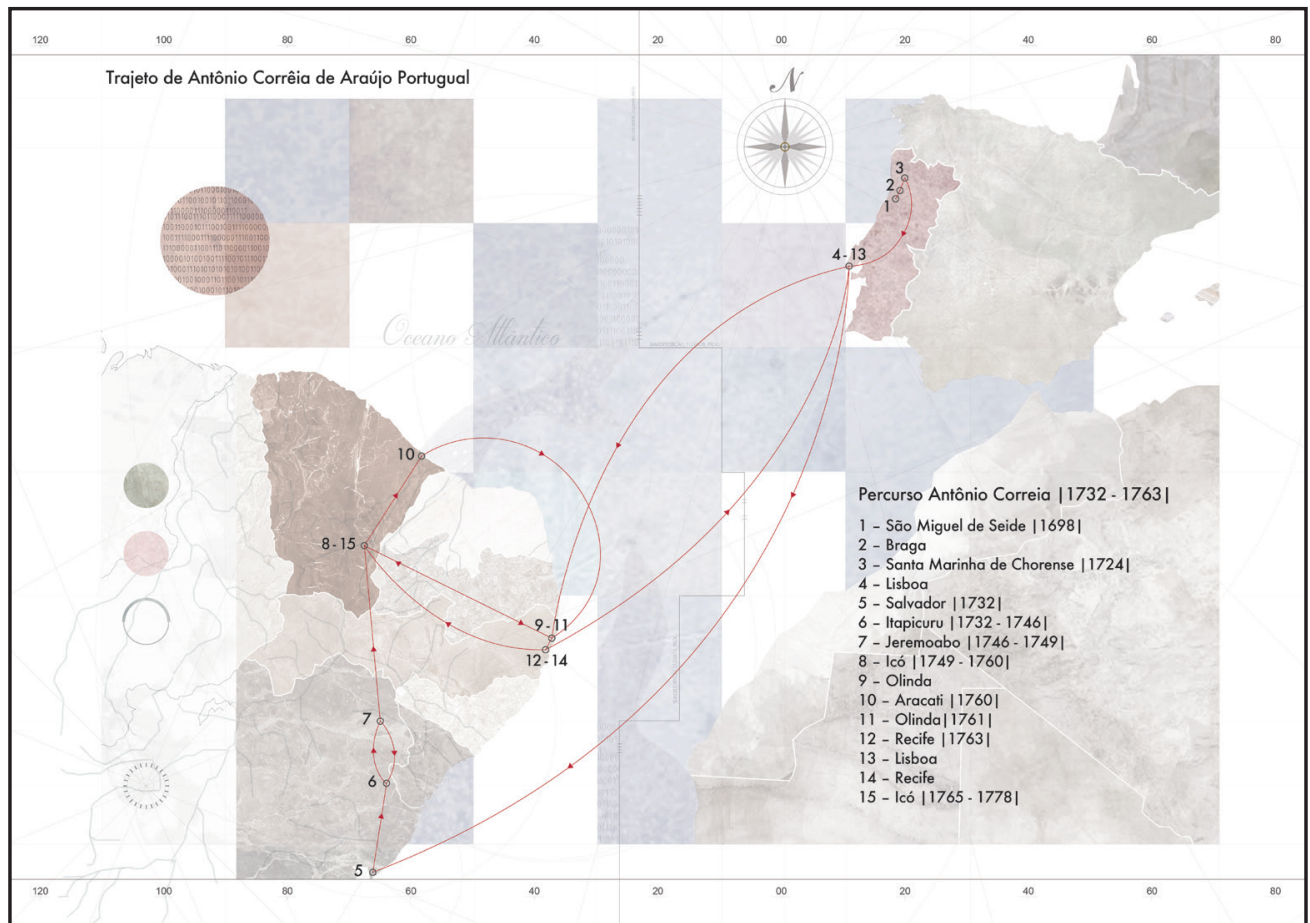

166. Sphan foi a primeira denominação do atual Instituto do Patrimônio Histórico e Artístico Nacional (IPHAN), que vigorou de 1937 a 1946 , período em que se deu a missão de Rescala ao Ceará.

167. Beserra (2018).

168. Processo de António Correia... (1759-1766).

169. Ibid., f. 37.

170. Ibid., f. 18.

171. Ibid., f. $50 \mathrm{v}$

172. Ibid., f. 14.

173. Ibid., f. 51v.
Figura 24 - Trajeto de Antônio Correia de Araúio Portugal. Fonte: Cartografia retrospectiva elaborada pelos autores com base nos dados do Processo n ${ }^{\circ} 6.269$ (1759-1766). ${ }^{173}$ 
174. Ibid., loc. cit.

175. Ibid., loc. cit.

176. Ibid., loc. cit.

177. Ibid., f. $47-47 v$.

178. Sobre a importância da Vila de Nossa Senhora da Expectação do Icó na rede urbana do Ceará no século XVIII, ver Primórdios da urbanização do Ceará, de Jucá Neto (2012b).

179. Mapa do estado da Fazenda... (1757)
Em 1732, Araújo Portugal deslocou-se para Lisboa, embarcando na "frota da Bahia"174 em direção a Salvador. Diz ter vivido mais de quinze anos entre a "mesma Cidade e seu recôncavo"175 e o sertão baiano, desempenhando atividades tanto no seu ofício de entalhador quanto como negociante de gados. Informa que assistiu por "dezasete anos sendo a mayor parte na villa do Itapicuru trabalhando pelo seu officio e negociando em fazendas que comprava e vendia". ${ }^{776}$ No sertão do Itapecuru arrematov em contrato real a obra civil - e provavelmente a decoração - da lgreja de São João Batista de Jeremoabo, riscando e comandando sua execução (Figura 25).

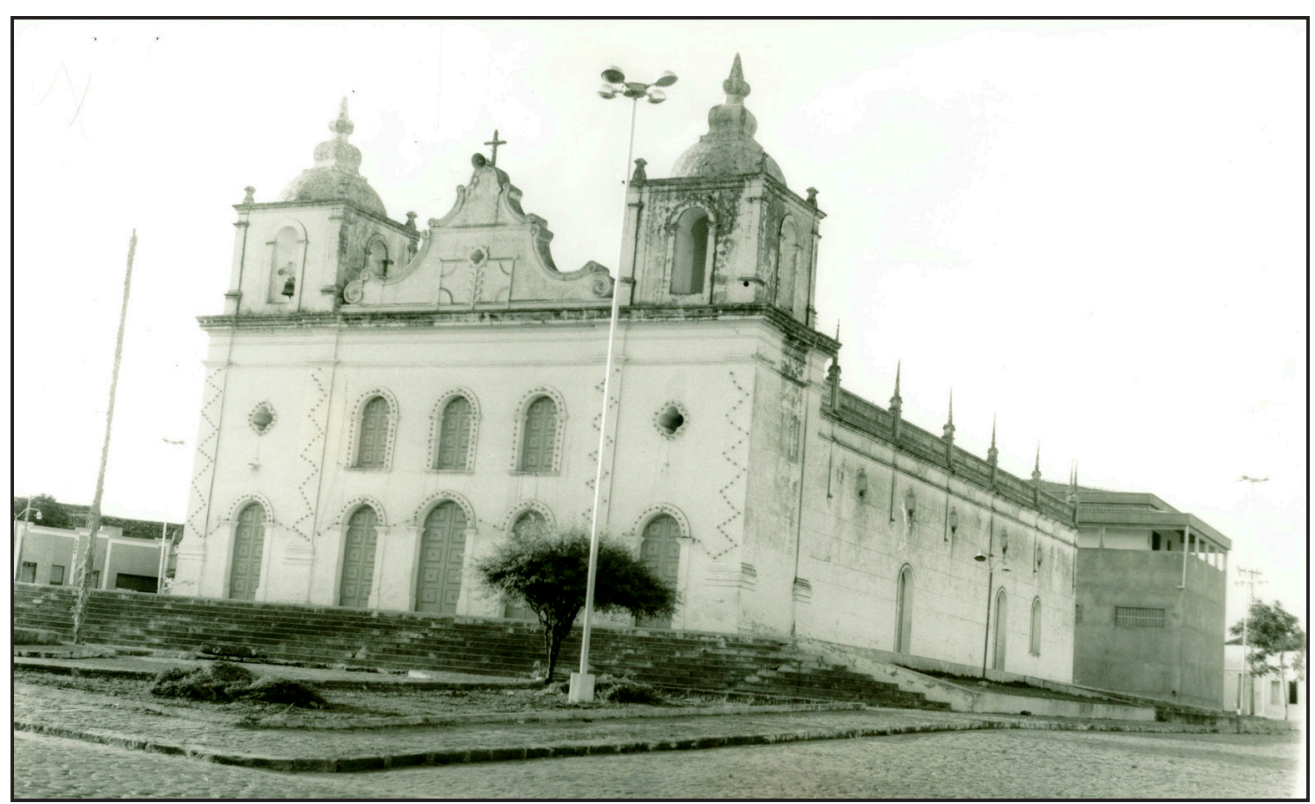

Figura 25 - Igreja de São João Batista, de Jeremoabo, Bahia. Foto: Instituło Brasileiro de Geografia e Estatística [s. d.].

Quanto a esta obra, em carta enviada ao artífice por Teodósio Machado de Andrade, um alfaiate morador da Bahia, em 1755, revela-se que Antônio Correia tinha "o dezeijo [...] de que se ponha a ultima perfissão, [...] ponderando o risco de Vm". Para dar cumprimento ao desejo de Correia Portugal, o alfaiate dizia ser "presizo dinhero para pagar a ofesiais nos creditos que devem a Vm", os quais reparariam a obra, sob a batuta de João Correia, irmão do entalhador. ${ }^{177}$

Por volta de 1750, Antônio Correia já se encontrava estabelecido no Ceará, na Vila de $1 c^{\prime},{ }^{178}$ e comandava a obra da igreja de Jeremoabo a distância, por orientações epistolares. À época possuía relação de negócios e amizade com potentados locais e, aparentemente, já dispunha de expressivo cabedal, posto que arrematou os dízimos reais do gado para a Ribeira dos Icós. ${ }^{179}$ Em 1755, casou-se pela segunda vez na Capela do Senhor do Bonfim 
(Figura 26), estando ainda viva sua primeira esposa em Portugal, motivo pelo qual foi processado por bigamia pela Inquisição de Lisboa.

A Capela do Senhor do Bonfim fora erguida a partir de 1749 por iniciativa do primeiro capitão-mor do lcó, o português Bento da Silva Oliveira. Em missiva de janeiro de 1755, Pedro Barbosa, outro entalhador bracarense, amigo de Antônio Correia e estabelecido em Salvador, declara que se "achará mto prompto em quanto ao servir o sr cappitao mor Bento da Silva de Olivra", o que the seria uma honra, e que faria o serviço com "fidelidade". ${ }^{180} \bigcirc$ entalhador Pedro Barbosa possivelmente executou ou adquiriu na Bahia as imagens sacras e talhas para a Capela do Bonfim, recémconstruída e financiada pelo potentado português. ${ }^{181}$ A Antônio Correia Portugal, seu amigo, coube intermediar a transação e, possivelmente, executar a obra da ermida.

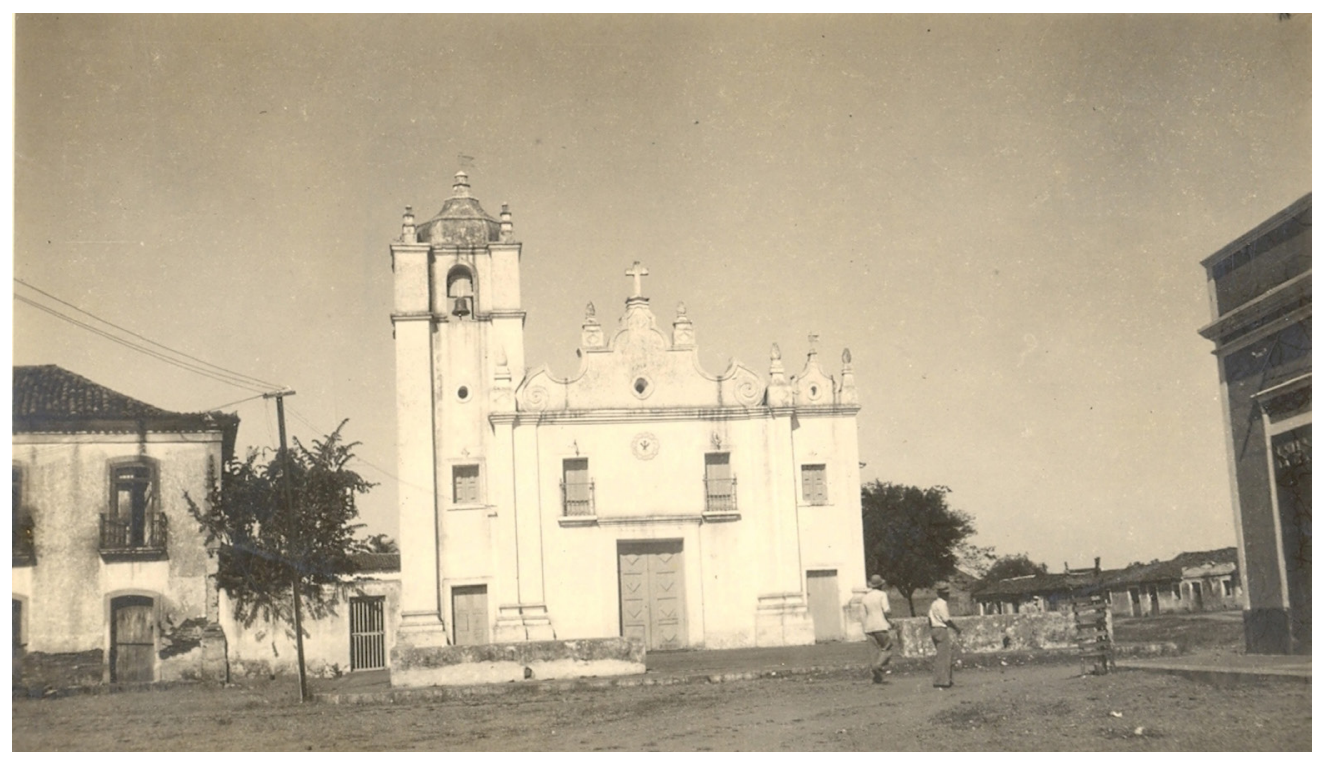

Figura 26 - Igreja de Nosso Senhor do Bonfim, de Icó, Ceará. Fonte: Acervo do Arquivo Noronha Santos, Iphan. Foto: João José Rescala, 1941.

Antônio Correia, proveniente de Braga, residiu em Salvador, Itapecuru (Bahia) e lcó (Ceará). No decorrer do processo inquisitorial, por diversas vezes, deslocou-se do lcó a Olinda, Recife e Lisboa, comparecendo às audiências e, finalmente, ao auto de fé em Portugal, quando foi condenado a degredo de cinco anos para a Vila de Castro Marim, Reino do Algarve. Na prisão do Santo Ofício viu-se despojado de seus pertences trazidos de lcó. Levara consigo "hua bolça com dous mil cento e trinta reais", "duas colheres", "hum par de fivelas", "duas chapas de colairinho", "hum sinete com letras do seo nome", "húa cruz da mão de S. Antônio de prata", "hum boldrié de carneiro encarnada com fivelas de prata", "húa ponteira de latam de espadim", "hú frasquinho com bucal de
180. Processo de António Correia..., op. cit., f. $45 \mathrm{v}$.

181. A tradição oral dá conta de que a imagem do orago da igreja viera da Bahia. 
182. Processo de António Correia..., op. cit., f. 5 .

183. Cf. Gomes; Paiva; Santos (2018).

184. Processo de António Correia..., op. cit., f. 93.

185. Livro $\mathrm{n}^{\circ} 19$ da Freguesia... (1777-1800, f. 3). chumbo", "húa |Nossa| Sr. a e um S. Antônio tudo de marfim", e "hum Christo de latão", tudo dentro de uma lata, além de maços de papel. 182 Entre os objetos particulares de entalhador, que sugerem a amplitude de suas posses, havia esculturas em marfim indo-português, o que novamente permite inferir que os sertões estavam integrados na rede de circulação de manufaturas e objetos de arte produzidos nos mais distantes pontos do Reino. Goa e Ceilão, atual Sri Lanka, foram centros dispersores dessa mercadoria que alcançou grande popularidade no mundo português entre os séculos XVII e XVIII. ${ }^{183}$

Após o cumprimento parcial da pena de degredo, o artífice conseguiu licença para retornar ao Ceará sob pretexło de acertar contas com a Fazenda Real, da qual era devedor. Em 1763, desembarcou em Recife e retornou para Icó. Em 29 de outubro de 1765, já "assistente nas partes da América na Villa do Icó", ${ }^{184}$ pede dilação de mais dois anos da licença com a justificativa de concluir suas contas. Uma nova licença the é concedida em 14 de novembro de 1765.

De retorno à Capitania do Ceará, o entalhador, iá quase septuagenário, realizou aquele que talvez tenha sido seu último trabalho conhecido: a talha do retábulo-mor da Igreja Matriz de Nossa Senhora da Expectação de lcó, já citada por Rescala. Diferentemente do retábulo executado em 1720, em Portugal, na aldeia de Chorense, em estilo nacional português, o retábulo de lcó já seguia a estética vigente à época, o rococó, com clara influência da escola pernambucana. Lembramos que o entalhador visitava amiúde a Capitania de Pernambuco. Antônio Correia faleceu no Icó e foi sepultado na já referida Capela do Senhor do Bonfim, em 1778, aos 80 anos de idade. ${ }^{185}$

Do antigo retábulo da Igreja de Nossa Senhora da Expectação de Icó restam fragmentos de um altar lateral, recentemente localizados, e o sacrário, que, contrapostos, nos permitem inferir traços característicos do trabalho de Antônio Correia Portugal: a mesma talha volumosa de profundos talhes; a mesma modenatura dos frisos; as mesmas estrias geométricas das cartelas com seus vértices recurvados internamente; a delicadeza dos buquês de rosinhas de malabar com seus miolos profundamente escavados, todos seguindo a mesma disposição na talha; as tarjas com rocailles simétricos envolvidos por ramos vegetalistas; as volutas; os pedestais dos colunelos idênticos aos do sacrário; além do douramento integral da madeira. Os fragmentos constam de um frontal de altar e da base do nicho que recebia alguma imagem. O sacrário foi construído a partir de uma seção poliédrica complexa, composta de curvas e contracurvas, cujos vértices são guarnecidos por colunelos e estípites à guisa de mísulas. Esse conjunto sustenta um entablamento com sanefa recurvada, alinhada ao gosto joanino. Todos esses elementos remanescentes apresentam grande similaridade com aqueles dos altares da Igreja de São Sebastião de Olinda, o que nos induz a pensar que o conjunto 
de lcó fosse bastante similar, ratificando novamente a ideia de repertório formal em circulação por meio da cultura material (Figuras 27, 28, 29 e 30).

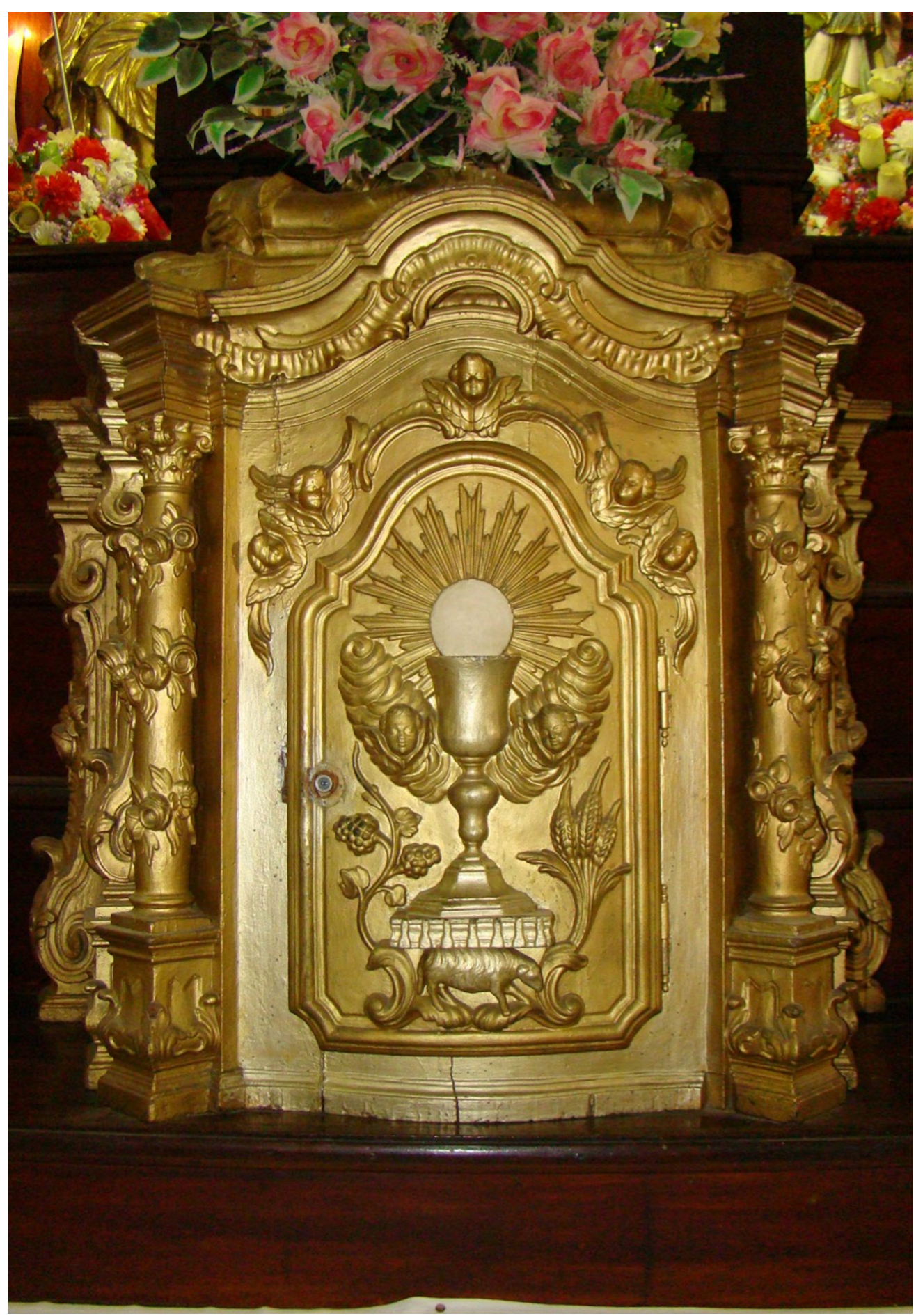

Figura 27 - Antigo sacrário da lgreja de Nossa Senhora da Expectação, de Icó, Ceará, entalhado por Antônio Correia de Araújo Portugal em 1765. Foto: Ramiro Teles, 2018. 


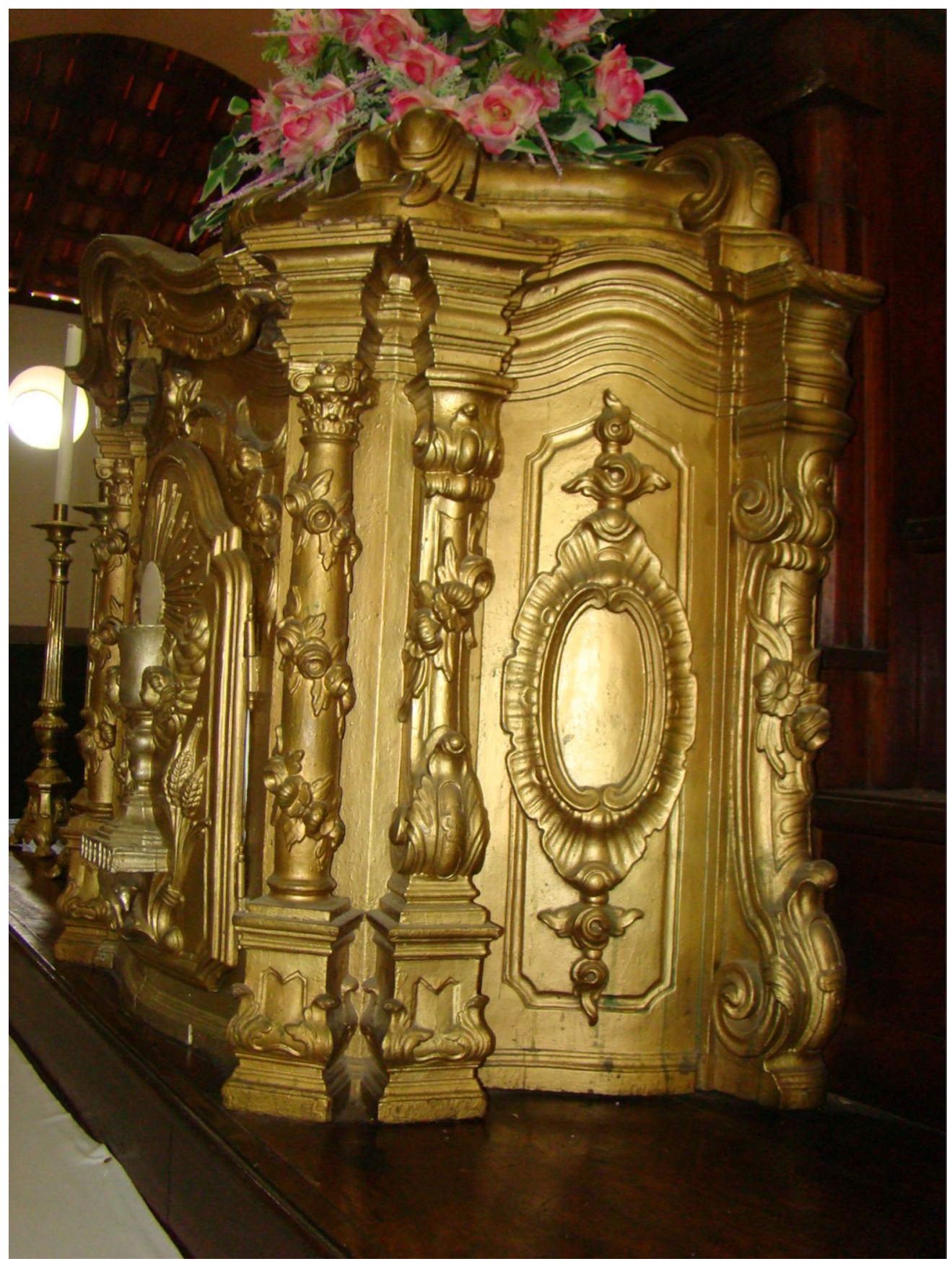

Figura 28 - Antigo sacrário da lgreja de Nossa Senhora da Expectação, de Icó, Ceará, entalhado por Antônio Correia de Araújo Portugal em 1765. Foto: Ramiro Teles, 2018. 


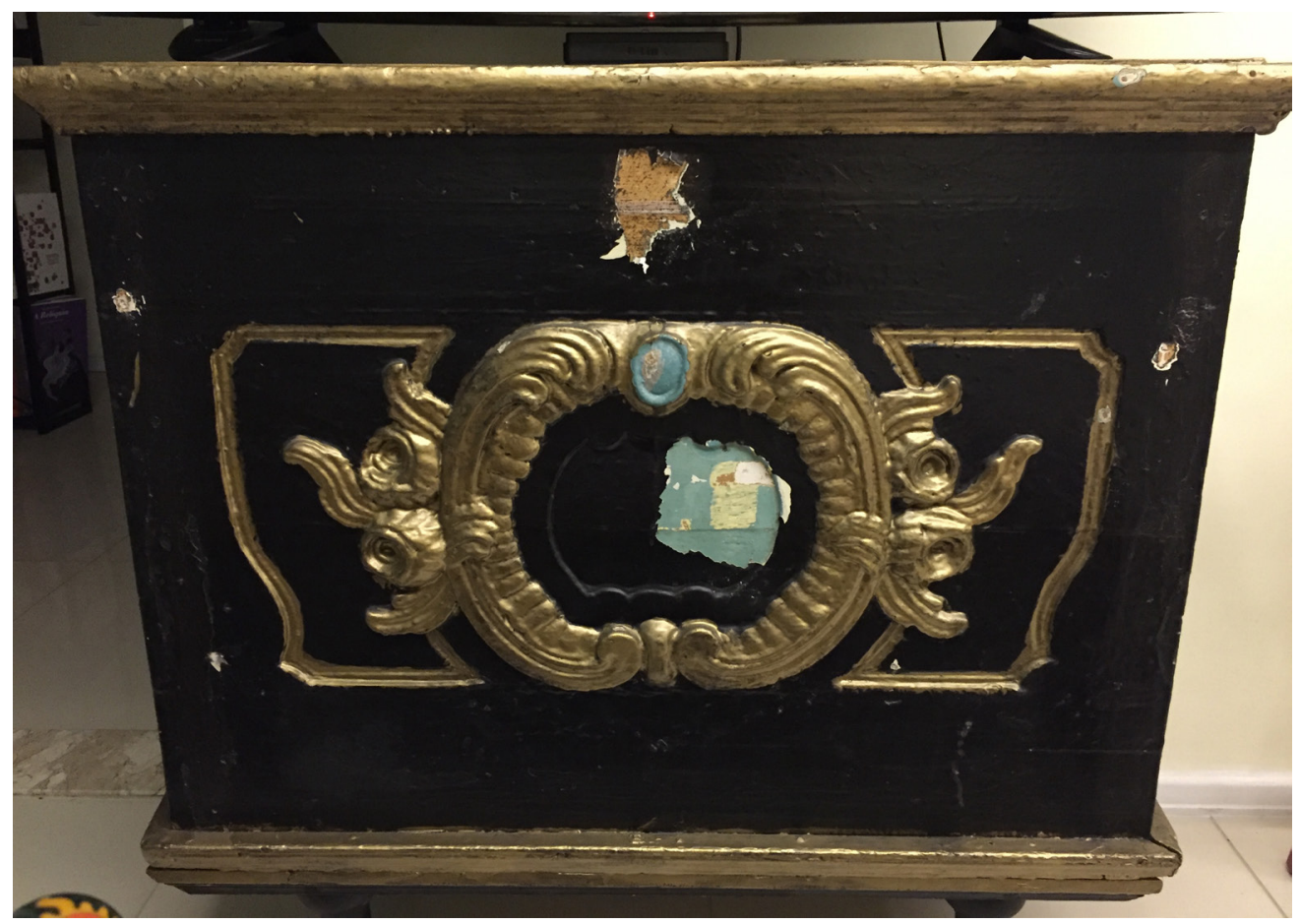

Figura 29 - Fragmento do antigo retábulo da Igreja de Nossa Senhora da Expectação, de Icó, Ceará, entalhado por Antônio Correia de Araújo Portugal em 1765. Foto: Ramiro Teles, 2018.

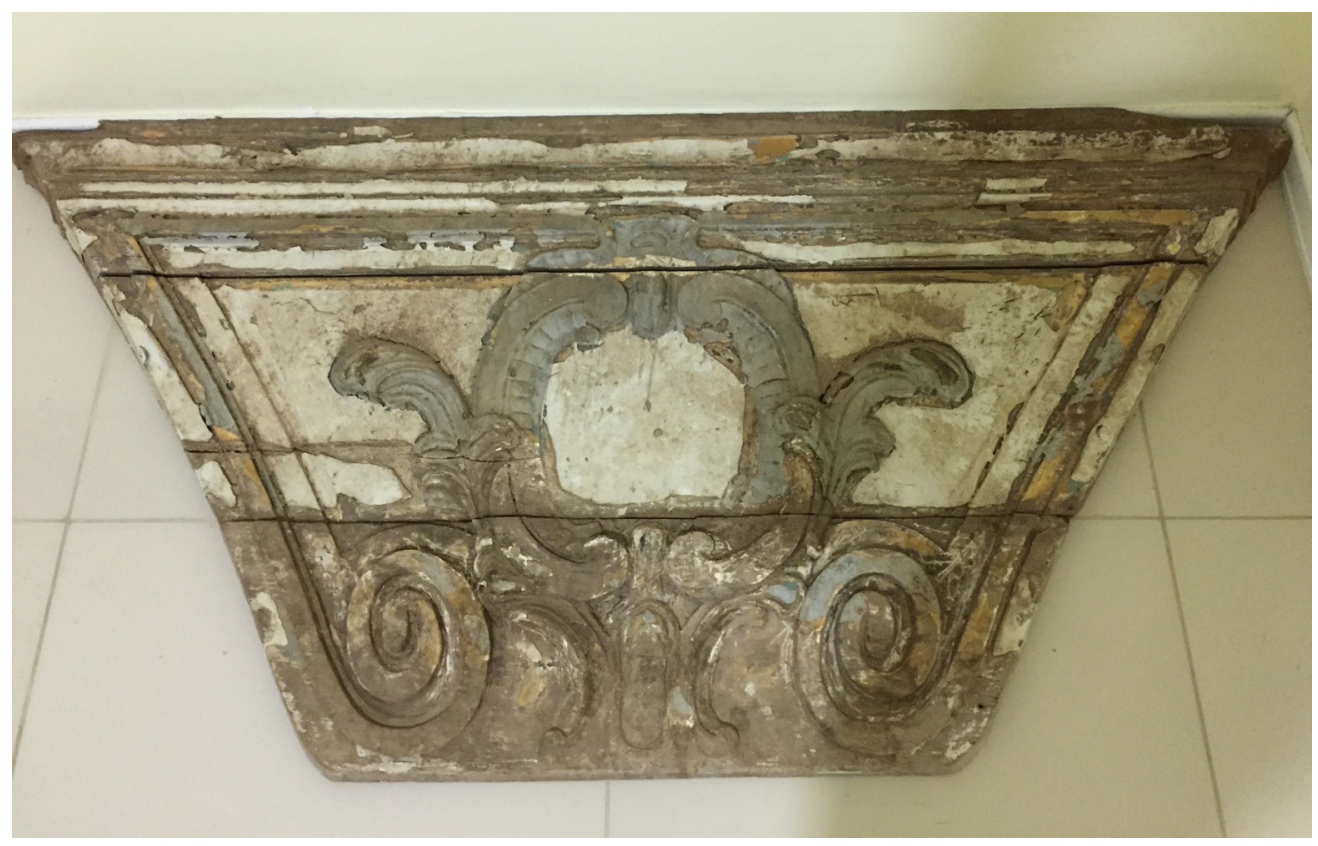

Figura 30 - Fragmento do antigo retábulo da lgreja de Nossa Senhora da Expectação, de Icó, Ceará, entalhado por Antônio Correia de Araújo Portugal em 1765. Foto: Ramiro Teles, 2018. 
186. Silva (2001, p. 135).

187. Acioli (2008, p. 196).

188. Situada à Rua Senador Pompeu, $\mathrm{n}^{\circ} 1.206$, em Fortaleza, Ceará.

189. Bueno (2012, p. 324).

190. Bueno (Ibid., p. 326) afirma que a expressão "desenho por escrito" é de Maria Fernanda Derntl.

\section{O artífice Félix Caetano e a capela-mor da Matriz de Fortaleza}

Atribuímos a autoria da talha do pequeno retábulo hoje existente na Capela de São Bernardo, em Fortaleza, ao artífice baiano Félix Caetano. $\bigcirc$ oficial de pintor, de ascendência africana, nascera livre na Cidade da Bahia por volta de 1732. 186 Ao que parece, consolidou seu ofício nos domínios da antiga Capitania de Pernambuco e suas subalternas. Em A identidade da beleza: dicionário de artistas e artífices do século XVI ao XIX em Pernambuco, Vera Acioli apresenta-nos Félix Caetano como pintor e dourador em atividade nos meados do século XVIII. A autora refere dois registros de pagamento de serviços prestados pelo artífice: um "na Ordem Terceira de São Francisco, [...] datado de julho de 1756, em que se pagou ao artista a importância de $12 \$ 000$ para pintar os frontais, não especificando de onde"; e outro, "de pagamento ao artista Félix Caetano, que pintou os painéis e dourou o nicho [ldem. Livro $3^{\circ}$ de Despesa, 1742-1760, fl. 97 e Livro $4^{\circ}$ de Despesa, 1760-1793, fl. 39]". ${ }^{187}$

Félix Caetano teve vida profissional longeva e bem considerada no meio artístico, posto que, na virada do século, ainda executava riscos por encomenda não só para importantes casas religiosas de Pernambuco, mas também para capitanias vizinhas, tal como o Ceará, o que reforça mais uma vez a existência de uma rede de intercâmbio de ideias e artífices em um território sem fronteiras artísticas.

O retábulo que atualmente existe na Capela de São Bernardo ${ }^{188}$ - e que pertencia à antiga lgreja Matriz de Fortaleza, demolida em 1938 - foi uma dessas encomendas. Trata-se de um exemplar de transição entre o rococó e o neoclássico, muito similar a outros exemplares pernambucanos coetâneos (Figura 31 ). $\bigcirc$ contrato em que figurava sua encomenda, assinado em 1795, juntamente com a obra civil da capela-mor do edifício, ilustra, em detalhes, a cadeia operatória recorrente de atores na produção arquitetônica do Brasil colonial. $\bigcirc$ documento ilumina as observações de Beatriz Bueno quanto ao modus operandi desse sistema no que se refere às obras públicas, com maiores ou menores diferenças, a depender do porte da obra e do núcleo urbano em questão: arrematantes, empreiteiros, artífices, fiadores. ${ }^{189}$ Questões pertinentes à fábrica são também abordadas, tais como técnicas construtivas, dimensionamento, materiais, além do próprio desígnio plástico, configurando-se esse contrato como um verdadeiro "desenho por escrito". ${ }^{190}$

A obra compreendia "levantar as paredes da dita Capella-mor quatro palmos pouco mais ou menos conforme for necessário", garantindo "boa simetria" com o corpo da igreja, formando "quatro óculos grandes, dous de cada parte logo abaixo da curnija", tudo "feito de tijolo e cal". Também consistia na execução do "novo Této [...] 
com caibros de pao d'arco faciados, com tizoiras, cumieiras e frexaes da mesma madeira, e travejamento para fazer o forro de esteira" e o forro, "tanto da capella-mor como do camarim". Consistia, também, no fazer do "Trono e Retabulo da mesma capella-mor de talha", e dos "degraos para o Altar a Romana", isto é, "descendo trez degraos para qualquer parte que se queira subir para o dito Altar, seja de frente ou dos lados, sendo os mesmos degraos de pedra lavrada das que se custume tirar nesta Freguezia". Faria ainda parte da obra "hum Altar, também da talha, bojudo pela frente na forma que hoje se uza". $\bigcirc$ "risco do Altar e de toda talha" foi "dado pelo pintor Félix Caetano, e aprovado pelo Rev. ${ }^{\circ}$ Parocho, tudo pela quantia de hum conto de reis". ${ }^{191}$
191. Studart (1896, p. 214216).

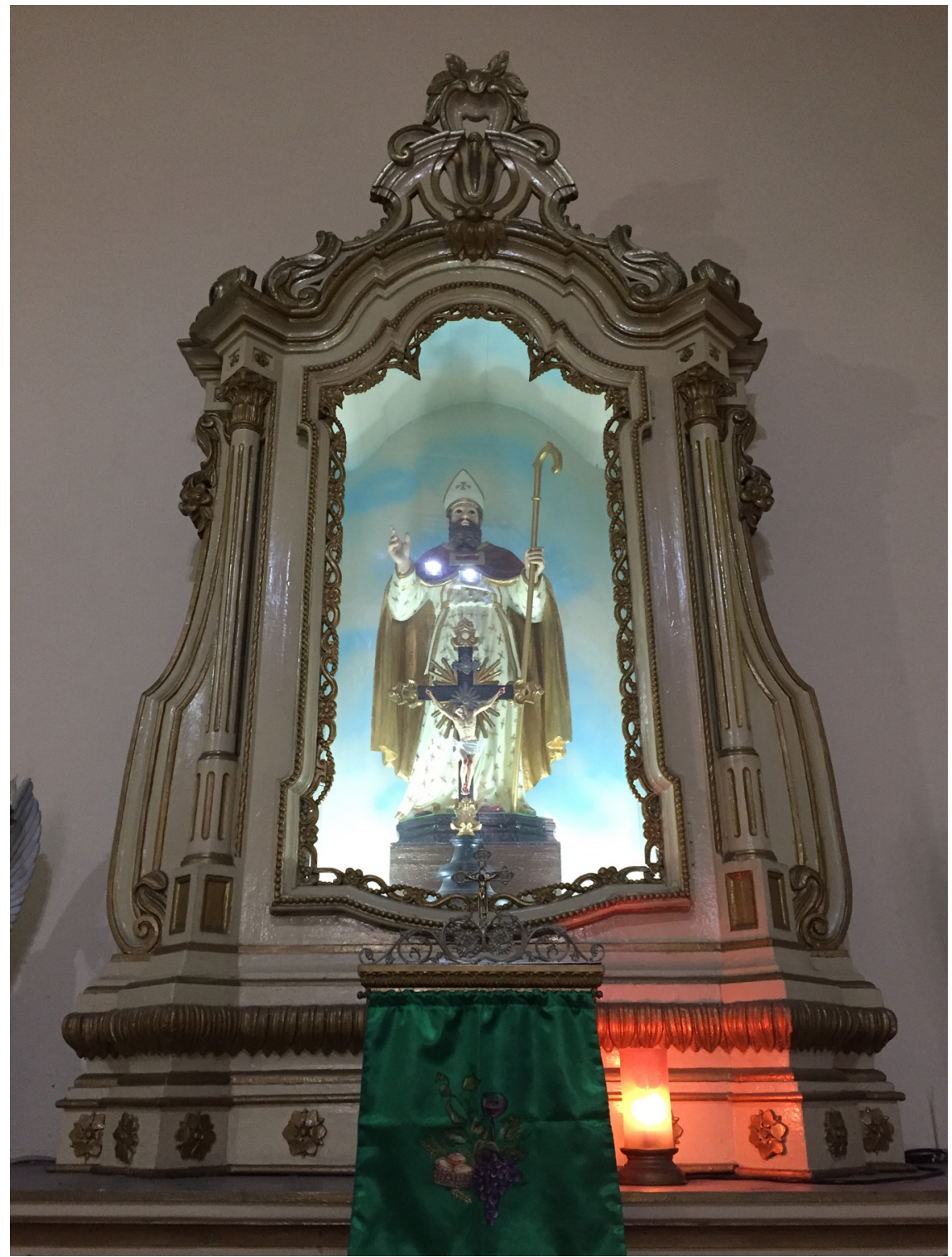

Figura 31 - Camarim do retábulo da antiga lgreja Matriz de São José, de Fortaleza, Ceará, contratado com Félix Caetano em 1795. Foto: Ramiro Teles, 2018. 
A julgar pelo tratamento estilístico da peça, condizente com a data do possível risco - entre 1795 e 1800 -, supomos que possa ser remanescente do conjunto de talha riscado por Félix Caetano, objeto do contrato referido. Percebe-se a existência de um altar bojudo, como o descrito no documento, ornamentado por elementos conchoidais ao estilo rococó. Em Sobral, no retábulo da lgreja de Nossa Senhora da Conceição, concluída em fins do século XVIII, há um camarim de fatura idêntica (Figura 32), o que reforça a hipótese da circularidade de riscos e repertório plástico. Possivelmente, o traço da talha idealizado em Pernambuco por Félix Caetano para a Matriz de Fortaleza foi reaproveitado na freguesia de Sobral quando da decoração da igreja recém-construída. Vale lembrar que, nesse edifício, outros elementos decorativos foram importados diretamente de Pernambuco, como foi o caso das portadas rococó talhadas em lioz, remetidas, por sua vez, de Portugal. ${ }^{192}$

Figura 32 - Camarim do retábulo da lgreja Matriz de Nossa Senhora da Conceição, de Sobral, Ceará. (séc. XVIII). Foto: Ramiro Teles, 2018.

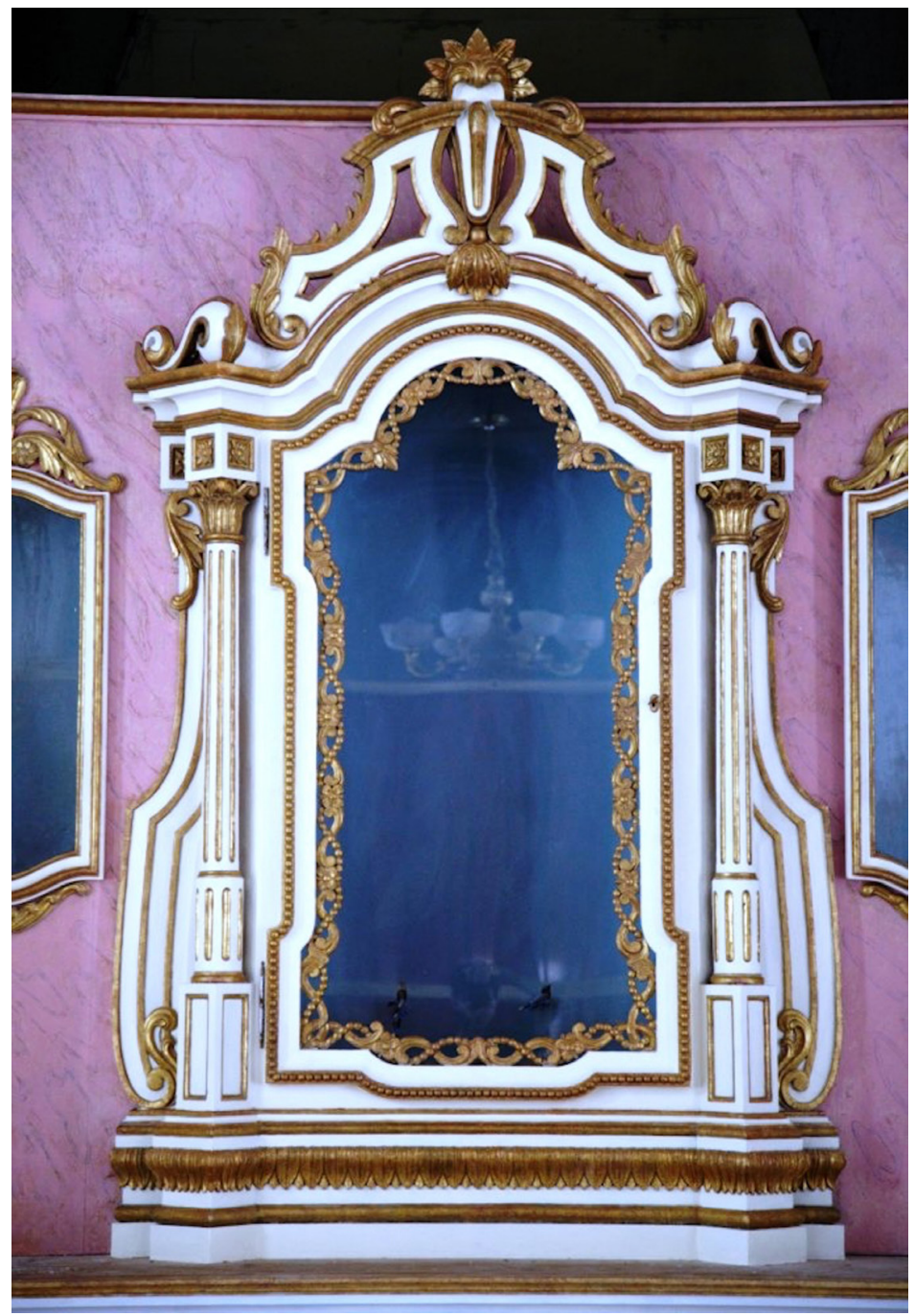




\section{O oficial pintor de Granja}

Se a arquitetura dos sertões e mesmo a escultura foram pouquíssimo estudadas e referenciadas, muito mais ressentida de figurar nas investigações foi a pintura colonial desses rincões. Mesmo que silenciada, ela existiu, e sua gênese encontra vínculos em longínquas conexões, aparentemente insólitas, que the renderam traços de uma particular hibridização - aspecto de grande riqueza para o desenvolvimento de futuros estudos de história da arte sobre a circulação de modelos na pintura colonial.

Não fossem a breve referência de Clarival do Prado Valladares ${ }^{193}$ aos painéis da capela-mor de São José de Aquiraz ${ }^{194}$ (Figura 33), ainda assim carregada de evidente prevenção quanto aos atributos artísticos da obra, ou os escritos de Liberal de Castro ${ }^{195}$ sobre os painéis da capela-mor de Viçosa do Ceará (Figura 34), tudo o que existiu, ou ainda existe, seria desconhecido e repelido. Chegou-se a afirmar, equivocadamente, a inexistência de relatos de pintura em forros lisos e contínuos, com técnica ilusionista, em território cearense. ${ }^{196}$

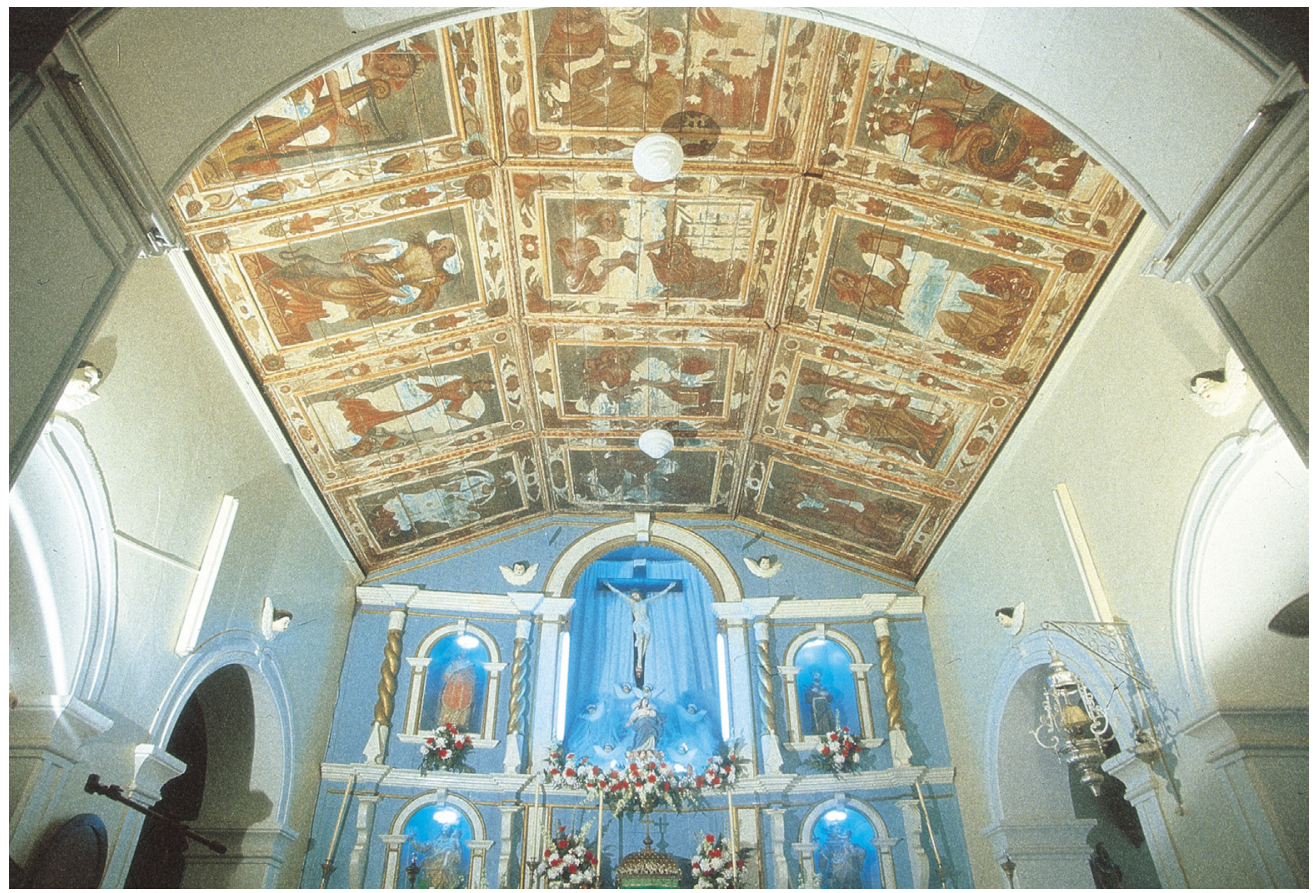

Figura 33 - Forro da capela-mor da Igreja Matriz de Nossa Senhora da Assunção, de Viçosa, Ceará (séc. XVIII). Foto: Arquivo Digital do Iphan, 2006.
193. Valladares (1983, p 166-167).

194. Cf. Beserra (2013). O autor revela a circulação de gravuras quinhentistas nos sertões, as quais serviram de modelo para a pintura no forro da Igreja de São José de Ribamar, em Aquiraz, Ceará.

195. Castro (2001, p. 91).

196. Id. (2001, p. 87). 
197. Martins (1915, p. 24)

198. Documentos transcritos do Livro de Contas do arquivo paroquial de Granja. Cf. Ibid.

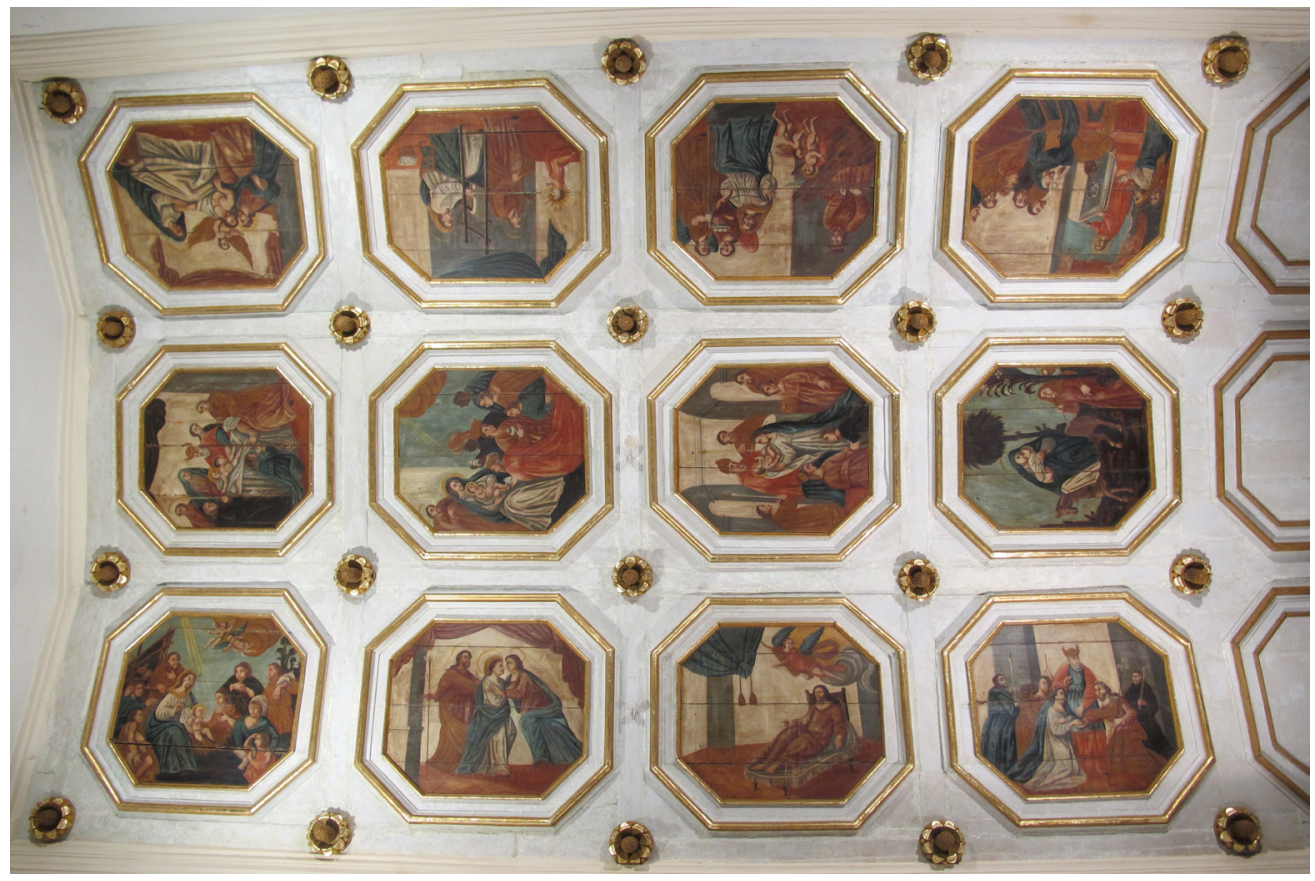

Figura 34 - Forro da capela-mor da lgreja Matriz de São José, de Aquiraz, Ceará (séc. XVIII). Fonte: Arquivo Digital do Iphan. Foto: Ramiro Teles, 2018.

Na antiga povoação da Macavoqueira, hoje cidade de Granja, a lgreja de São José guardava duas preciosas capelas laterais, patrocinadas por duas irmandades fundadas em 1759: a Irmandade do Santíssimo Sacramento e a do Bom Jesus dos Navegantes. Cada agremiação esforçou-se em ornamentar suas capelas com o que de mais luxuoso poderia haver para as possibilidades oferecidas pelo sertão: a decoração composta por retábulos em talha, imaginária devocional, óleos sobre tela e forro liso em madeira policromada com pinturas rococó em perspectiva, simulando falsas arquiteturas.

Em 23 de dezembro de 1792, lavrou-se acordo dos confrades da Irmandade do Bom Jesus dos Navegantes para "trazer da Praça de Pernambuco não só o oficial como [...] tintas para dourar e pintar a Capella [...] e mais acessórios que precizar para ornamento da mesma Capella". ${ }^{197}$ A Irmandade do Santíssimo Sacramento aproveitou, na ocasião, a presença do referido artista para também executar a "decoração memorável" de sua capela, composta de "ricas douraduras e pinturas", além do quadro da Ceia Larga. Em 18 de novembro de 1798, a obra estaria concluída com o "douramento da Capella". ${ }^{198}$ Os registros, mais uma vez, reverberam o fluido intercâmbio de artífices e mestres, frequentemente acionados para atuar nos sertões, promovendo a integração de territórios distintos por meio de seus ofícios, técnicas, ideias e formas. Lamentavelmente, nos idos dos 
anos 1950, as duas capelas foram destituídas de seu espólio artístico com reforma inadequada procedida pelo monsenhor Manuel Vitorino de Oliveira. ${ }^{199}$

A decoração de ambas as capelas apresentava filiação nitidamente rococó, notadamente com a escola pernambucana. A talha do retábulo da Capela do Santíssimo Sacramento tinha execução mais apurada, ocupando toda a sua largura. Apresentava requintada policromia em jaspeado e douramentos associados a entalhes em rocaille em todos os seus elementos compositivos. Sua base era composta pela mesa de altar bojuda, com tarja central entalhada. Acima desse tramo da base, descansam os plintos que sustêm dois quartelões com enrolamentos na base e coroamento. Em sua porção média havia entalhada uma cartela oval com rocalhas. Os quartelões, elementos reminiscentes do estilo joanino anterior, enquadravam um grande arco central dentro do qual estava encaixada a tela com a representação da Santa Ceia. Acima dos quartelões, capitéis amparavam fragmentos de frontão mistilíneo com típicas rocalhas rococó assimétricas, elemento recorrente na retabulística rococó mineira, carioca e pernambucana. ${ }^{200} \mathrm{Nas}$ fotografias antigas, atrás do frontão central do retábulo, é possível entrever fragmentos das pinturas em rocaille do forro (Figura 35).

Oretábulo da Capela de Bom Jesus dos Navegantes apresentava menores proporções, quase similares às de um oratório móvel adossado à parede do fundo. Também policromado com marmorizados e douramentos, sua base era conformada por uma mesa de altar de formato cúbico cuja face frontal, em vitrine, acomodava a imagem do Senhor Morto. Apoiados na mesa estavam os plintos dos quartelões, similares a estípites, que delimitavam o nicho central em que estava depositada a imagem do orago (Figura 36). Ainda que mais alinhado à estética rococó, o retábulo tinha como arremate da composição um elemento ainda de influência do barroco joanino: um dossel composto por uma ampla sanefa ondulada guarnecida por lambrequins e encimada por rocailles, com solução muito similar àquela do retábulo da Capela de Nossa Senhora da Conceição da Jaqueira, em Recife, ou do retábulo do coro alto do Mosteiro de São Bento, em Olinda.

Nessa capela, havia uma requintada pintura rococó no forro agamelado. Seu partido compositivo era típico das pinturas congêneres do rococó em Pernambuco, caracterizado por um espaço vazio na abóbada, no qual parece flutuar um medalhão central emoldurado por arquiteturas cenográficas (Figuras 37 e 38). 201 
Figura 35 - Capela do Santíssimo Sacramento da lgreja de São José, de Granja, Ceará (1792-1798). Fonte: Acervo do Arquivo Noronha Santos, Iphan. Foto: João José Rescala, 1941.

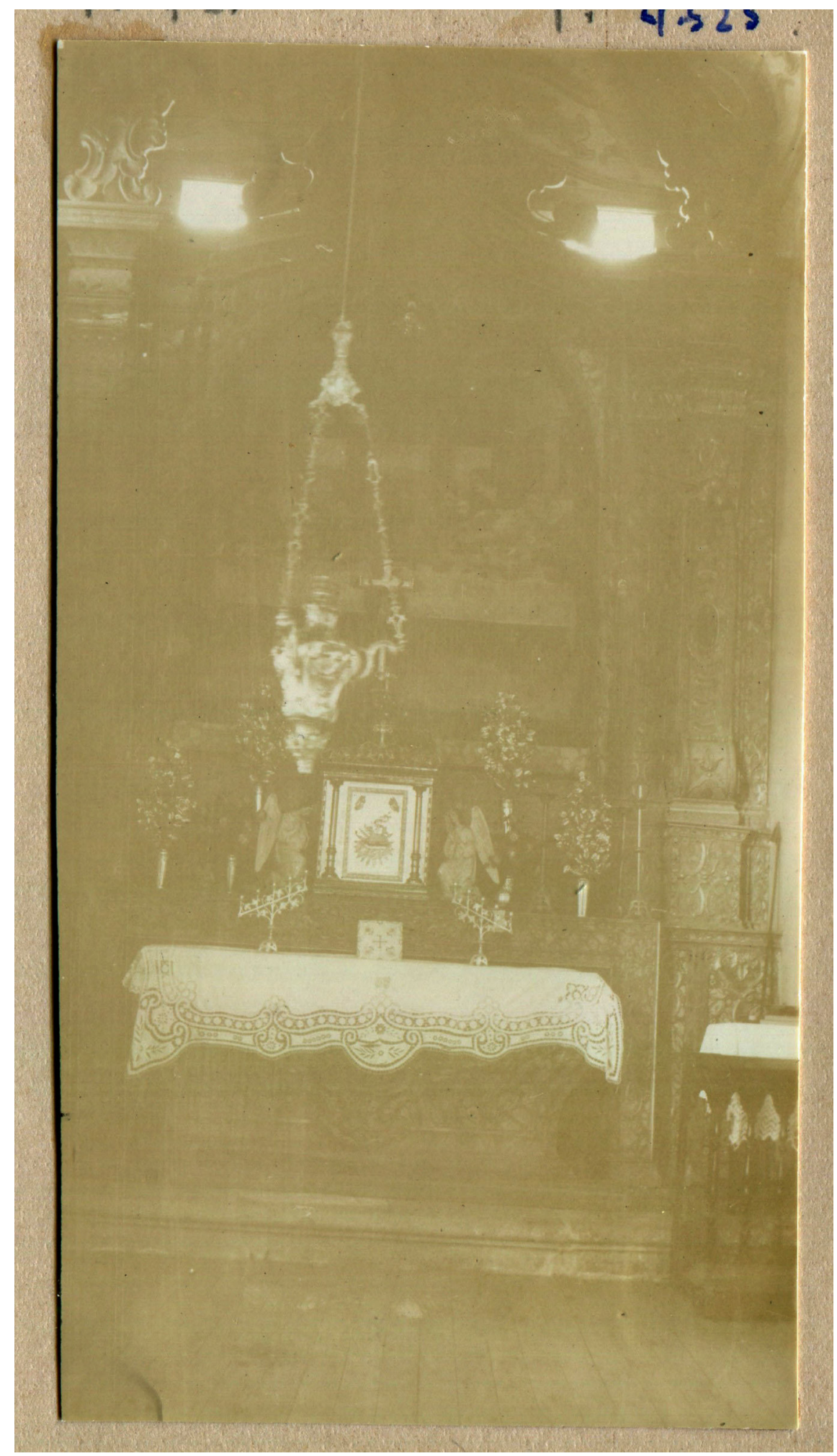




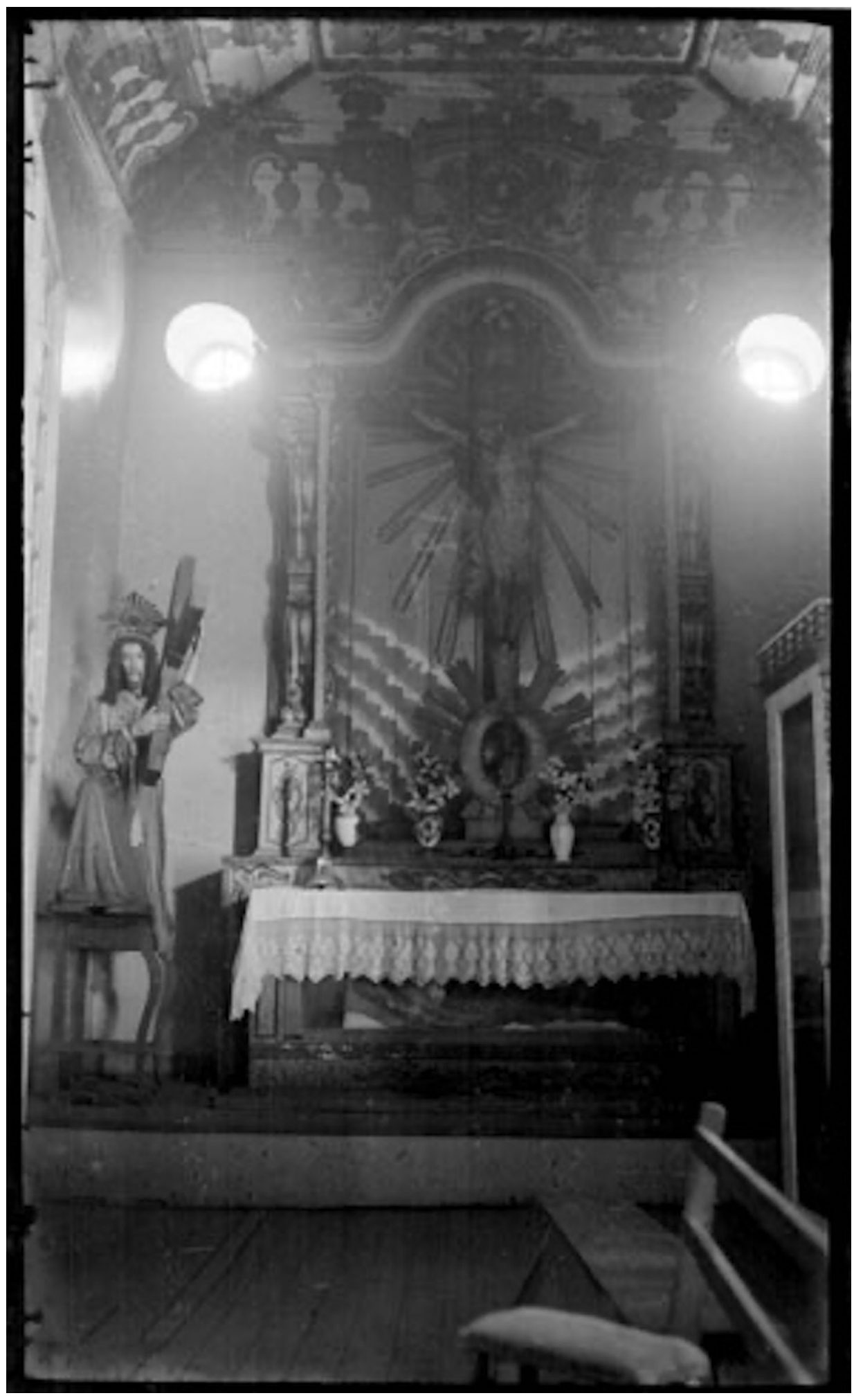

Figura 36 - Capela do Bom Jesus da lgreja de São José, de Granja, Ceará (1792-1798). Fonte: Acervo do Arquivo Noronha Santos, Iphan. Foto: João José Rescala, 1941. 
Figura 37 - Forro da Capela do Bom Jesus da lgreja de São José, de Granja, Ceará (1792-1798). Fonte: Acervo do Arquivo Noronha Santos, Iphan. Foto: João José Rescala, 1941

Figura 38 - Forro da Capela do Bom Jesus da Igreja de São José, de Granja, Ceará (1792-1798). Fonte: Acervo do Arquivo Noronha Santos, Iphan. Foto: João José Rescala, 1941
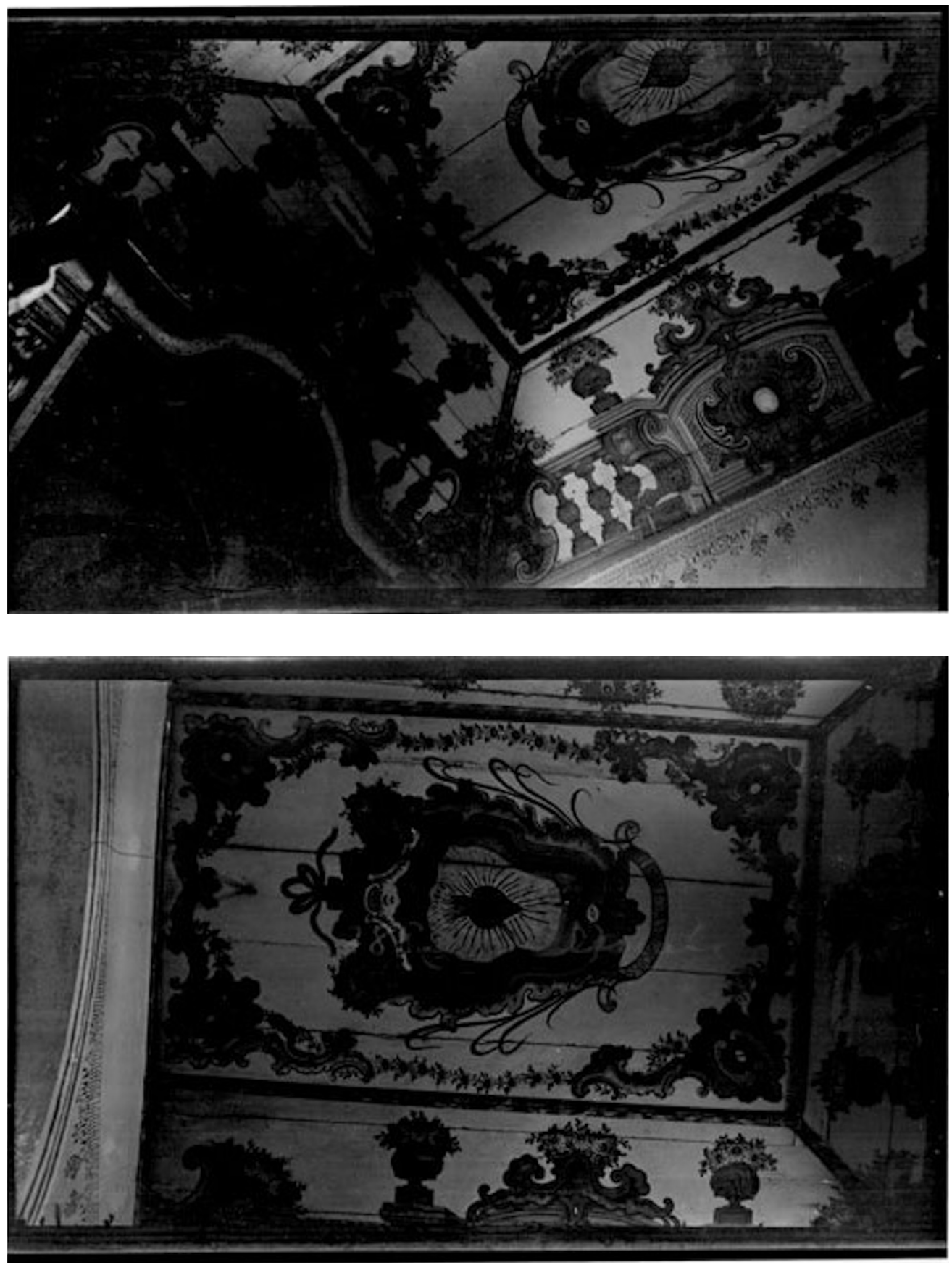

O referido quadro central era composto por uma tarja na qual figurava um coração flamejante emoldurado por rocalhas simétricas, laçarotes e buquês de flores. Abaixo da tarja, pendia uma fita com o lema "S.' Bom Jezuz [ilegível]". Guarnecendo a tarja central, uma nova moldura de rebuscado desenho rococó 
delimitava os limites do plano horizontal da gamela. Nas três faces pendentes do forro, desenvolvia-se uma mureta em perspectiva conformada pela associação de uma balaustrada corrida interrompida por arquiteturas cenográficas à guisa de balcões (Figura 39), os quais são decorados com medalhão central em volutas e sustentados por possantes mísulas contracurvadas. Sobre as mísulas, descansavam vasos floridos e, no encontro das faces do forro, a pintura duma cartela com volutas simétricas arrematava a emenda.

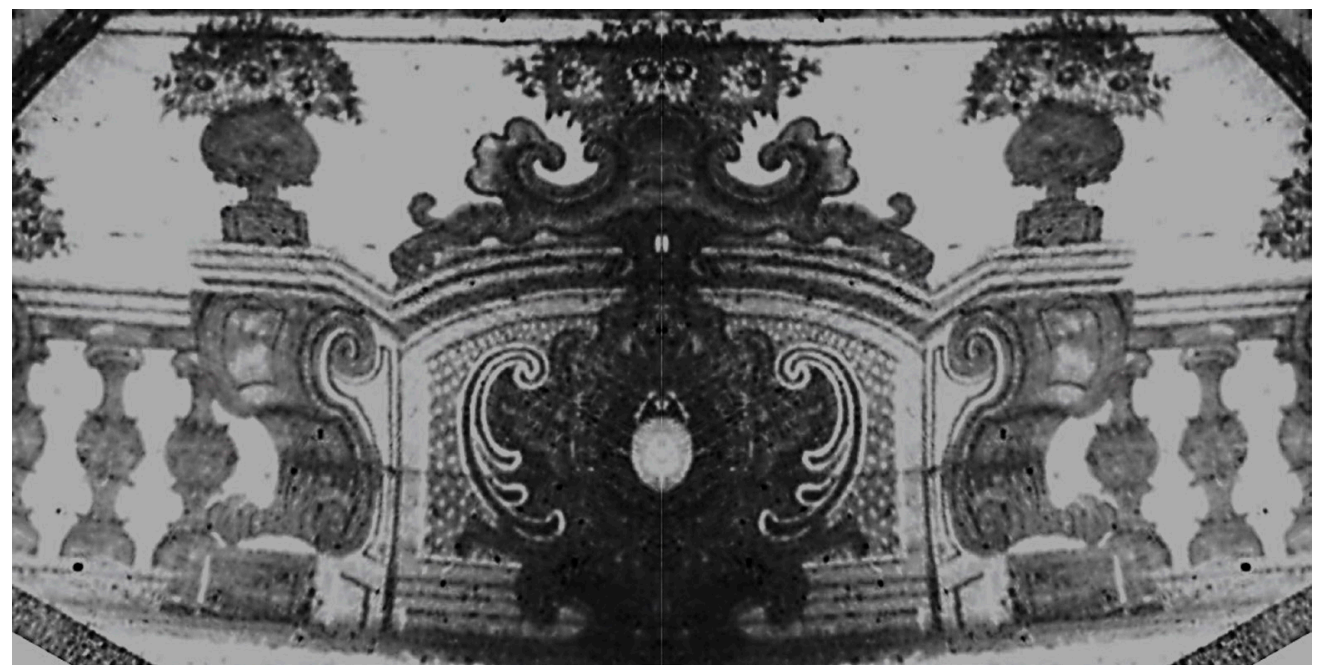

Figura 39 - Detalhe do forro da Capela do Bom Jesus da Igreja de São José, de Granja, Ceará (1792-1798). Fonte: Acervo do Arquivo Noronha Santos, Iphan. Foto: João José Rescala, 1941.

Essa descrição encontra paralelo no que Myriam Oliveira observou para diversos exemplares da pintura pernambucana em forros de igrejas. ${ }^{202}$ Num exame comparativo, percebe-se extrema semelhança entre a pintura da igreja cearense e a composição pictórica da lgreja da Misericórdia, de Olinda, o que permite especularmos se teriam mesma autoria ou, no mínimo, se a pintura cearense seria inspirada naquela pernambucana. É notável a similitude das tarjas centrais, que têm exatamente os mesmos contornos, havendo somente a adaptação de motivos associados à sua respectiva invocação. Os balcões pintados em ambas as obras também apresentam grande semelhança, guarnecendo-os um medalhão em volutas ao centro e os vasos em flores assentes sobre pesadas mísulas em contracurvas. Um outro exemplar olindense também guarda semelhanças com a pintura do forro da Capela do Bom Jesus, de Granja: trata-se da balaustrada de mesma perfilatura representada no forro da nave da Igreja de São Bento, com o mesmo artifício de arremate dos vértices da balaustrada, qual seja, uma cartela em volutas de igual desenho ao de Granja (Figuras 40 e 41 ). 
Figura 40 - Detalhe do forro da Capela do Bom Jesus da Igreja de São José, de Granja, Ceará (1792-1798). Fonte: Acervo do Arquivo Noronha Santos, Iphan. Foto: João José Rescala, 1941.

Figura 41 - Detalhe do forro da nave da lgreja do Mosteiro de São Bento, de Olinda, Pernambuco (séc. XVIII). Foto: Ramiro Teles, 2016.
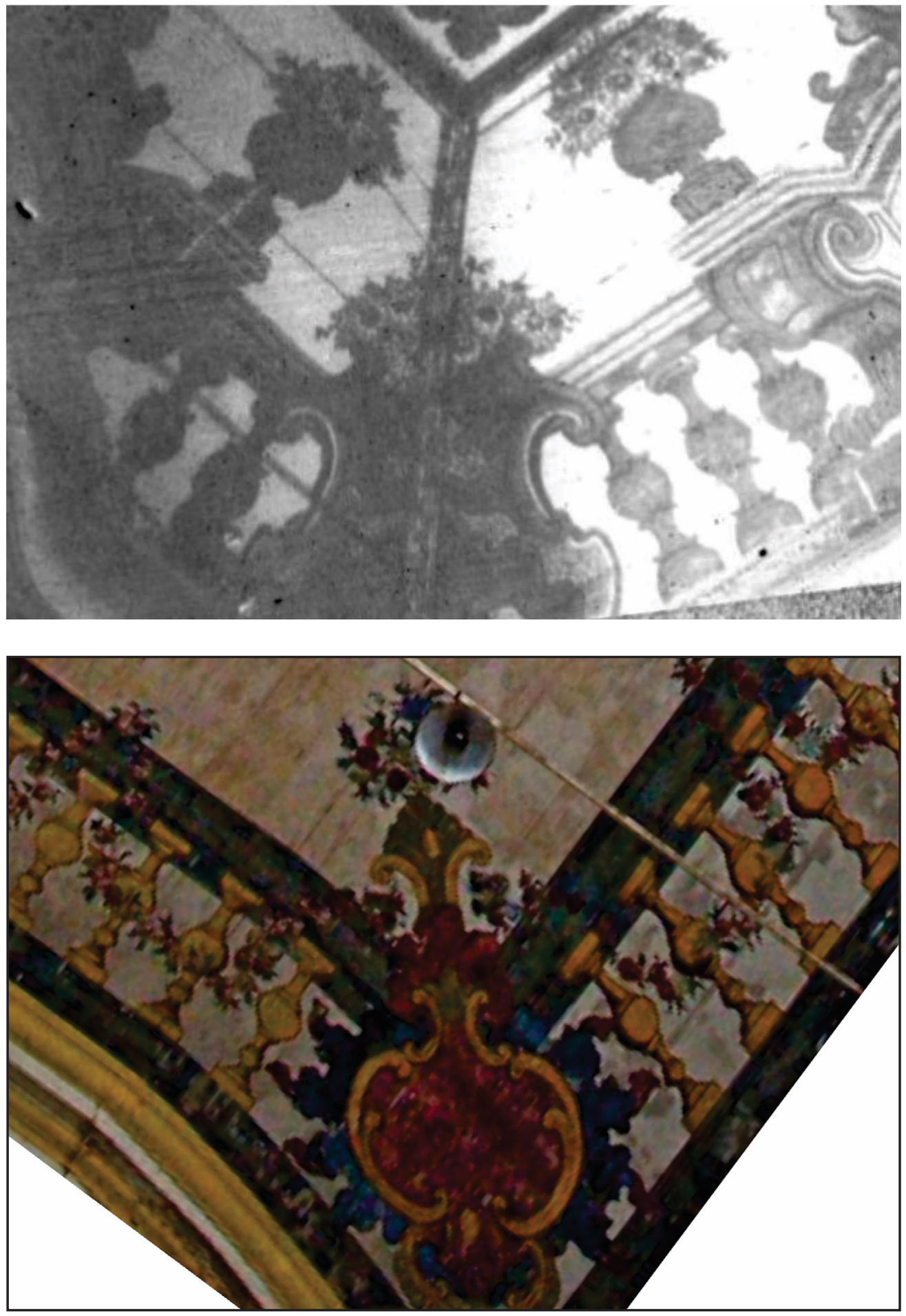
Conhecem-se, ainda, outros exemplares de pinturas de forro ao estilo rococó em capelas cearenses. Na Capela de Nossa Senhora da Conceição de ltans, sertões do Choró, a pintura do forro da capela-mor apresenta-se em uma composição reticulada, obtida por meio do uso de molduras estruturadas nas tesouras de linha alta da coberta da capela-mor, as quais conformam nove painéis (Figura 42). $\bigcirc$ uso das referidas molduras, em conjunto com a aposição do motivo policromado recortado sobre fundo branco, confere autonomia pictórica a cada um dos quadros, semelhante às soluções obtidas nos forros ditos de caixotão. Pintados com a técnica de têmpera sobre madeira, a temática dos painéis diz respeito a emblemas votivos às virtudes marianas, ferramenta visual grandemente utilizada pela lgreja contrarreformista.

Seis daqueles painéis, paralelos à inclinação do telhado, exibem um vaso dourado de amplas alças com rosas desabrochadas e outras em botão, todos apoiados sobre plintos perspectivados. $\bigcirc$ tema do vaso de flores foi fartamente utilizado na decoração de forros de igrejas no Brasil, especialmente durante o período de vigência do rococó. ${ }^{203}$ Os outros três quadros estão dispostos na faixa central e plana do forro agamelado. Partindo, respectivamente, do arco-cruzeiro para o altar-mor, sucedem-se da seguinte forma: o primeiro apresenta um quartelão com influência de versões dos brutescos maneiristas. No segundo, o painel central exibe um medalhão barroco com suas curvas, contracurvas e concheados que orlam uma cartela octogonal contendo o seguinte lema em latim: "Inmaculata Conceptione Beate Mariae Virgins sit nobis Salus \& Protetio" (Figura 43). ${ }^{204}$ Trata-se do lema da Ordem dos Marianos da Imaculada Conceição, fundada em 1671 pelo padre Stanislaus Papczynski, natural da região da Boêmia. Desconhece-se como tal inscrição pode ter chegado à capela cearense ainda em meados do século XVIII. Provavelmente, como já se adiantou, foi por meio da circulação de gravuras em livros e missais (Figura 44).
203. Ibid., p. 284.

204. "Imaculada Conceição Beata Virgem Maria seja nossa Saúde e Proteção" (tradução nossa). 


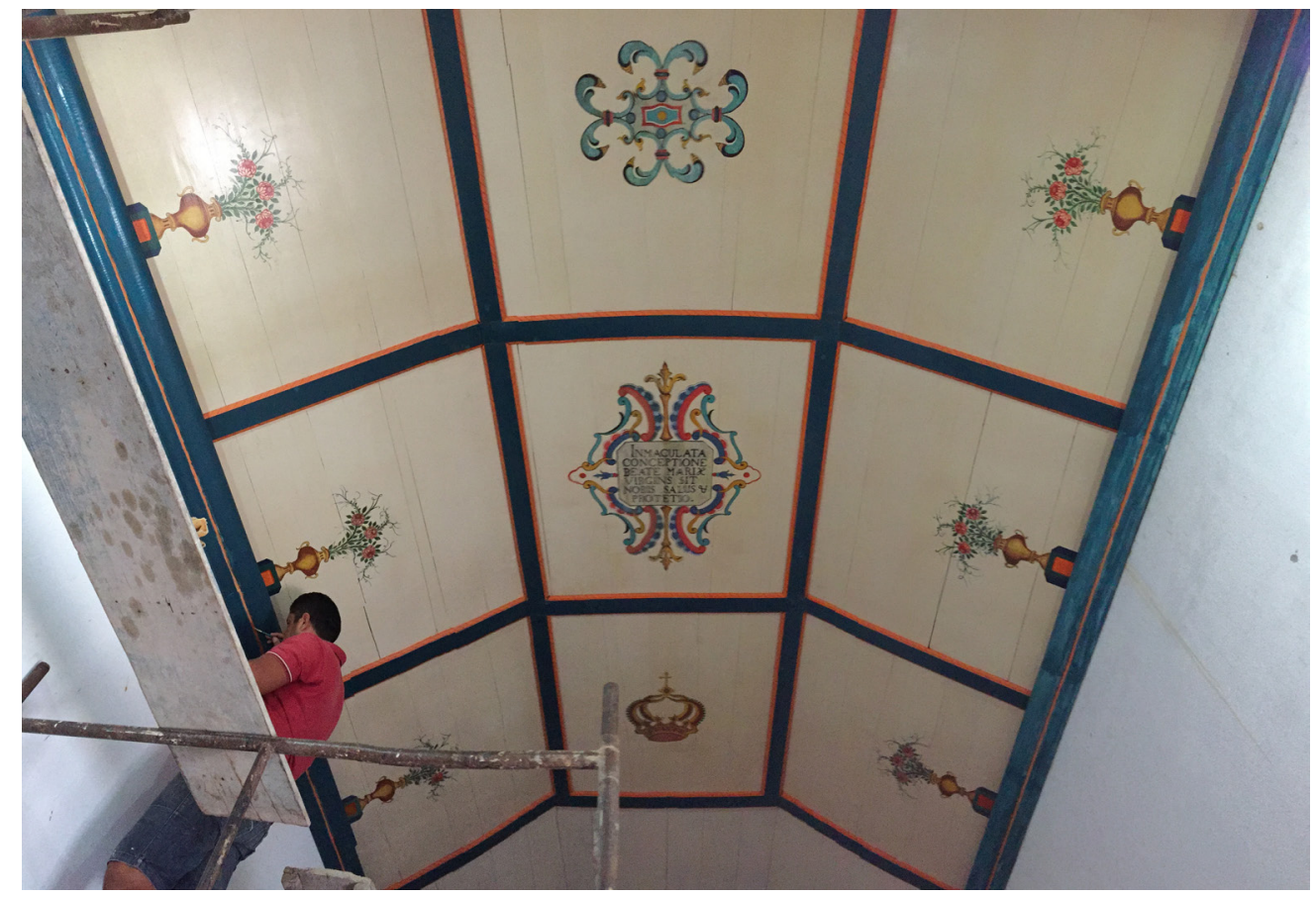

Figura 42 - Forro da capela-mor da Capela de Nossa Senhora da Conceição, de Itans, Ceará (c. 1770). Foto: Ramiro Teles, 2018.

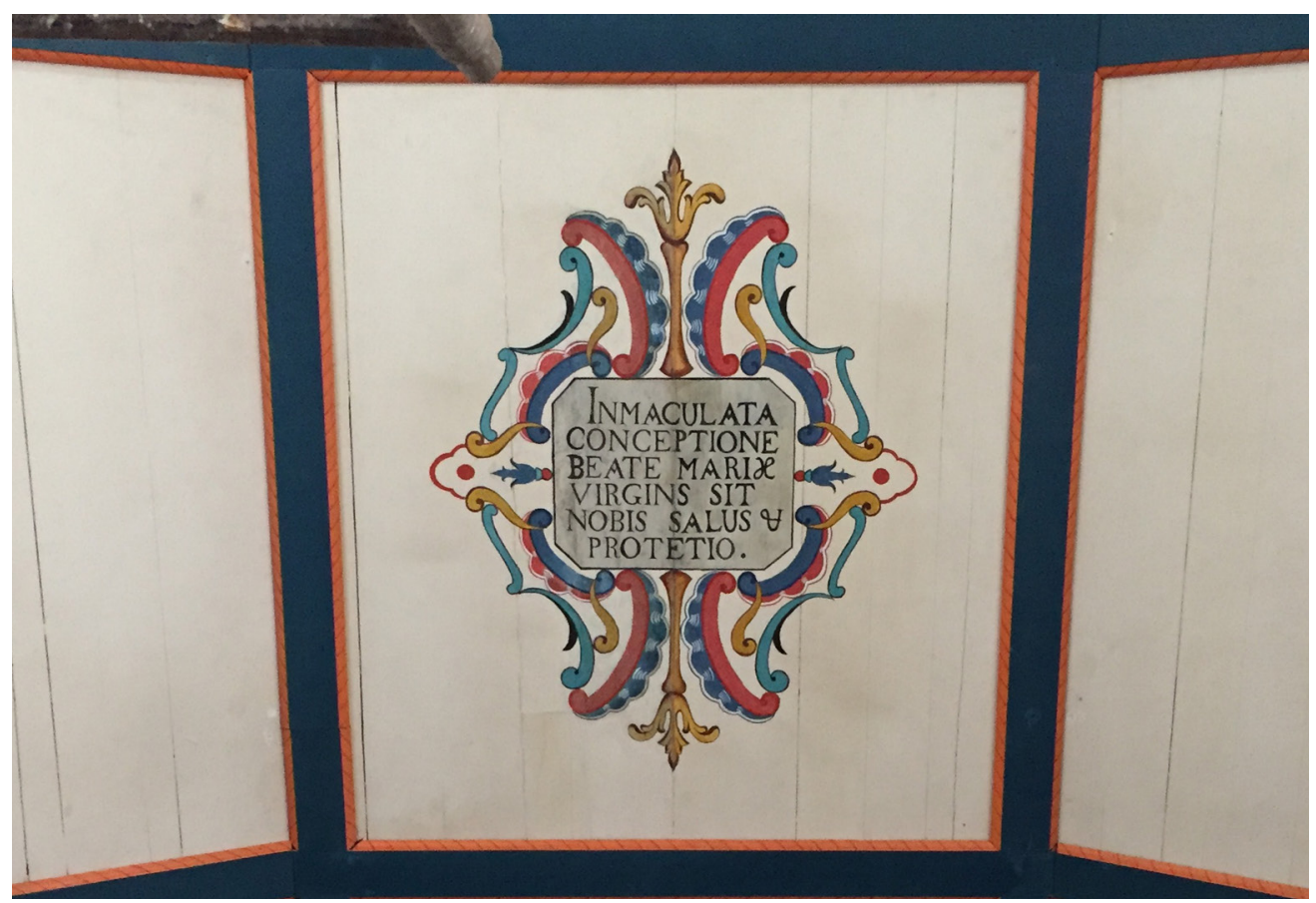

Figura 43 - Tarja central do forro da capela-mor da Capela de Nossa Senhora da Conceição, de Itans, Ceará (c. 1770). Foto: Ramiro Teles, 2018. 


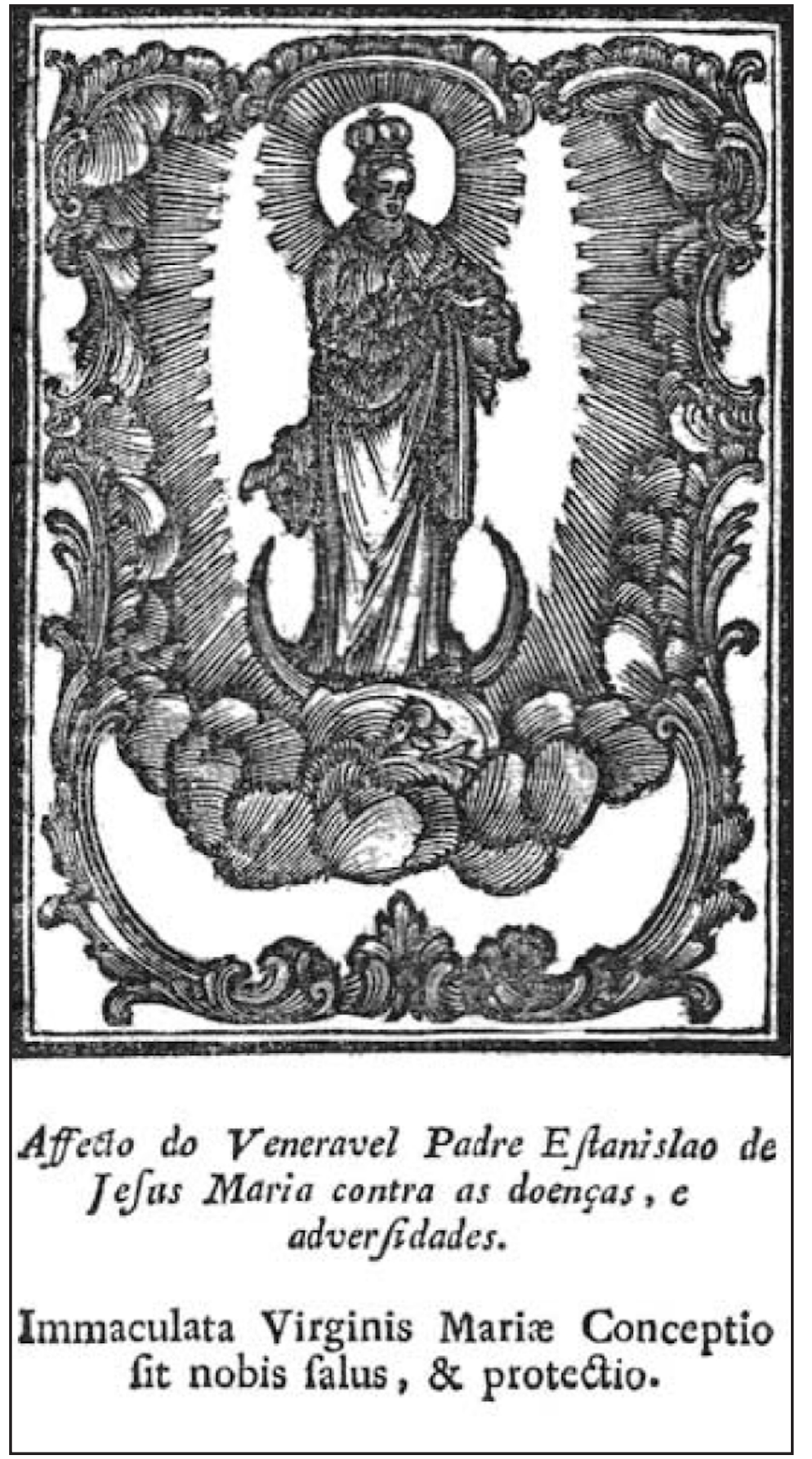

Figura 44 - Folha de rosto do opúsculo Estatuto da Confraria da Immaculada Conceição..., publicado em Lisboa em 1758. Fonte: Estatuto... (1758).

O terceiro e último painel, o mais próximo ao altar-mor e à escultura de Nossa Senhora da Conceição, apresenta a típica coroa portuguesa fechada, alusão aos títulos de Regina das ladainhas marianas ou da Litania de Loreto, tema recorrente na pintura colonial brasileira. 

do forro da capela de Itans seria retomado, de forma adaptada, aplicado em outra pintura, na capela-mor da lgreja de Nossa Senhora do Rosário dos Pretos, de Quixeramobim, construída em 1783. ${ }^{205}$ A edificação apresentava o teto de seu presbitério forrado com tábuas corridas de madeira policromadas, com um medalhão barroco de grandes proporções centralizado.

O desenho concebido para o forro da Capela do Rosário de Quixeramobim era a combinação de dois dos painéis da capela-mor de Itans, ou seja, trazia a tarja em rocaille do painel central, sem a cartela em latim, no lugar da qual se enxertou o desenho da coroa do outro painel. Isso resultou num desenho idêntico, apenas com ajustes de escala, ao qual se ajuntou um rosário, alusão ao orago do templo dos escravos de Quixeramobim (Figura 45).

Os exemplos aqui apresentados convergem para iluminar a hipótese de que a arte e a arquitetura religiosa colonial dos sertões são resultado direto da dinâmica circularidade de indivíduos, formas e ideias estéticas, em franco processo de síntese e transculturação, desconstruindo a ideia de insularidade desse território.

Figura 45 - Tarja do forro da Capela de Nossa Senhora do Rosário dos Pretos, de Quixeramobim, Ceará (séc. XVIII). Fonte: Acervo do Arquivo Noronha Santos, Iphan. Foto: João José Rescala, 1941.

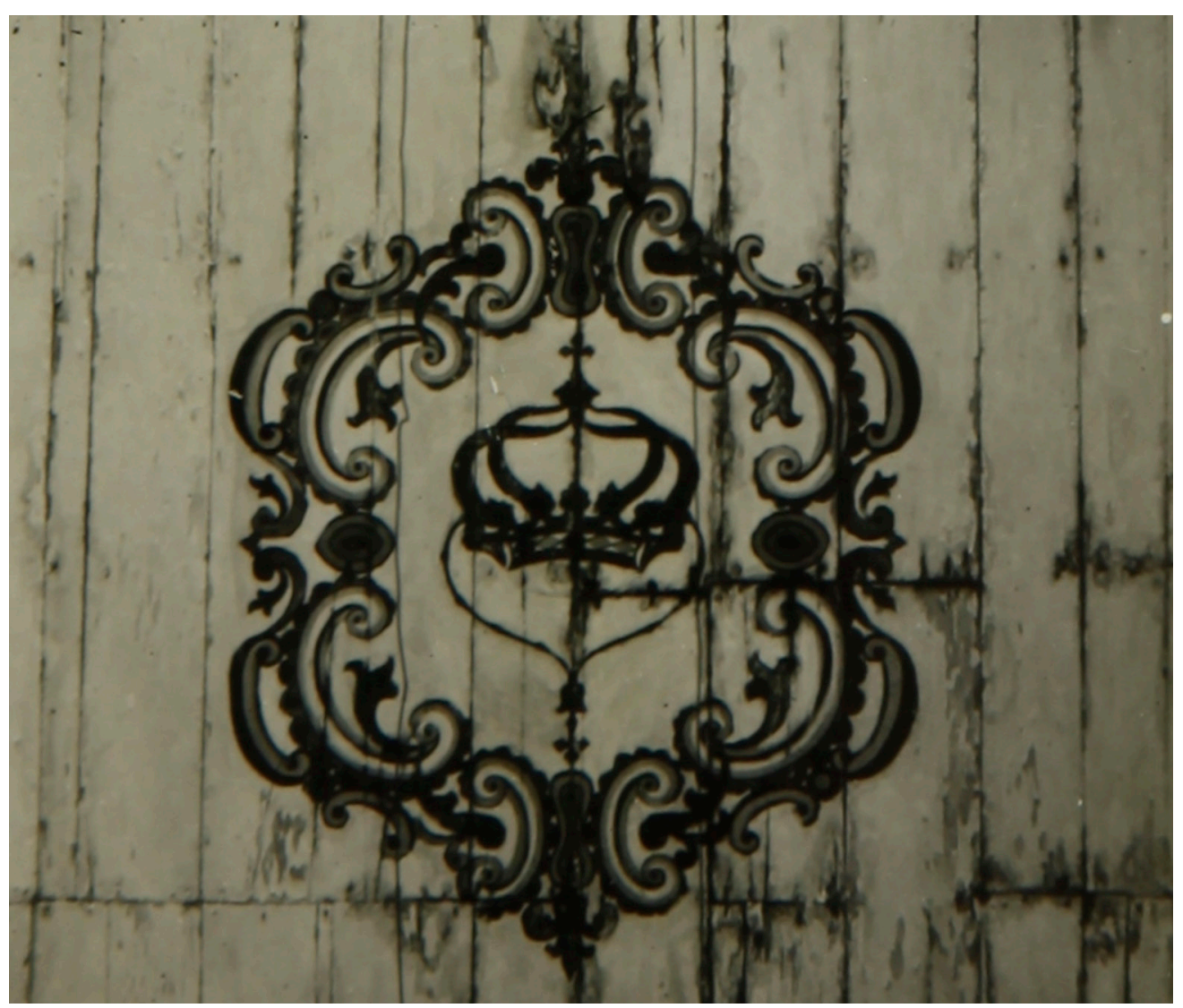


Ajustada ao espírito da época, a arquitetura religiosa do Ceará colonial se aproximava de ressonâncias e arcaísmos morfológicos oscilantes entre traços maneiristas ou barrocos, circulando e dando corpus e suporte às ideias dos homens de seu tempo. ${ }^{206}$ No entanto, mais do que enquadrá-la em estilos arquitetônicos específicos, importa identificar por quais caminhos e conexões fluíram e circularam os predicados que the deram sentido unitário, coerente e coeso ao longo do período colonial, independentemente de quaisquer pretensas classificações estilísticas.

Além de ser sempre referida como uma arquitetura despojada, essencial, adaptada ao meio árido em que foi erguida, um outro aspecto seu muito revisitado é que se trata de uma arquitetura anônima, extraindo-se desse adjetivo um pretenso viés de obra ordinária, de composição tacanha e fortuita, obtusa e incidental. Ocultou-se sempre no discurso do anonimato a face do desinteresse inerte dos estudiosos da área por essas obras dos sertões do Norte, alheado à fartura da cana e do ouro. Já em 1948, Gustavo Barroso proferia acutilada crítica a esse respeito, em artigo na revista $\bigcirc$ Cruzeiro, afirmando que "nada sabemos do que em matéria de arte tenham realizado os modestos homens do Ciclo do Gado", 207 referindo-se às diversas capelas erguidas nas antigas fazendas sertanejas, a exemplo da Capela de Nossa Senhora da Conceição, de Cococi (Figura 46).

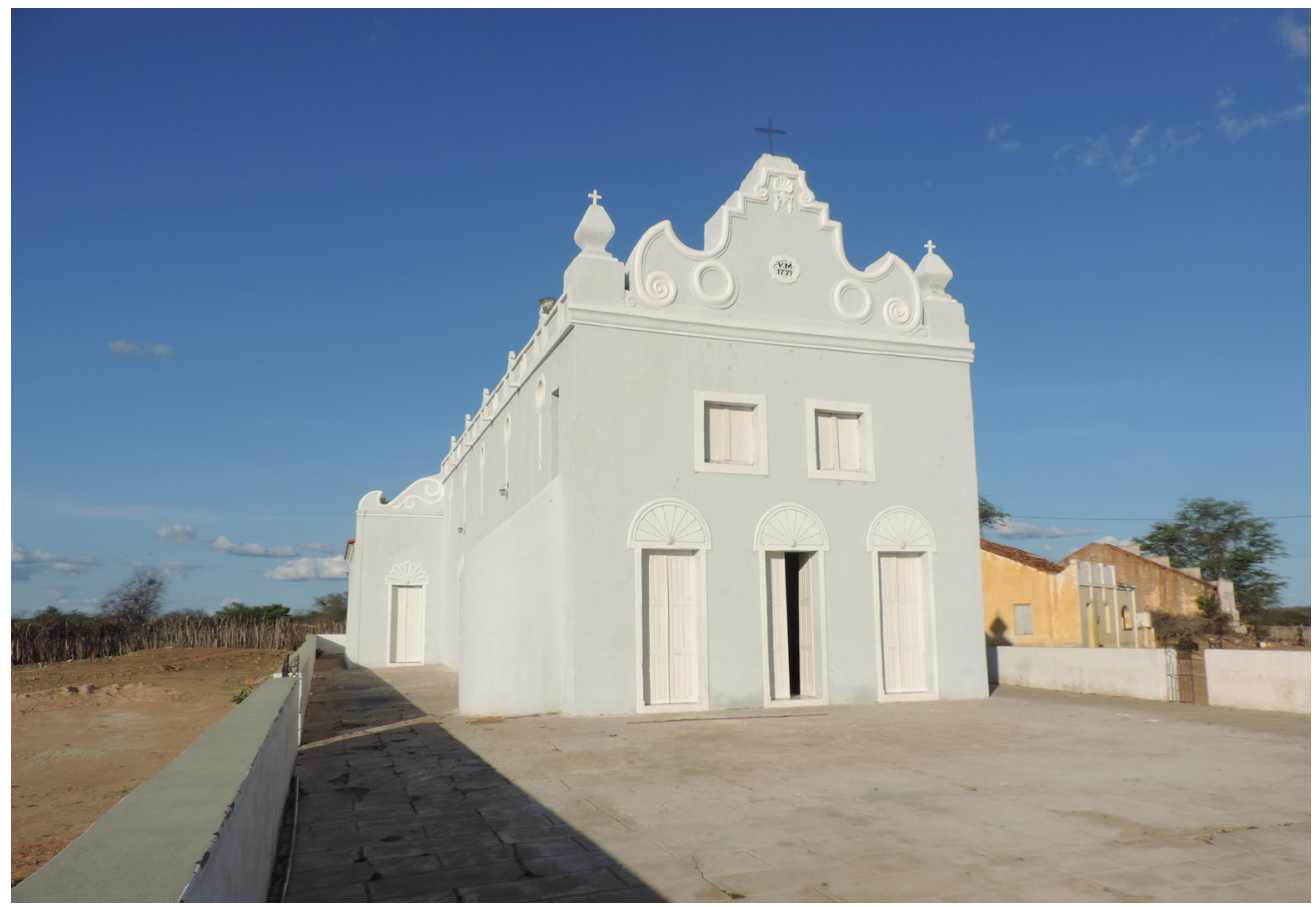

Figura 46 - Capela de Nossa Senhora da Conceição, de Cococi, Ceará (1740). Foto: Ramiro Teles, 2018. 
208. Processo de António Mendes... (1761).

209. Ibid.

210. Ibid., f. 6v.

211. Ibid., f. 46.

212. Ibid., f. 6v.

213. Ibid., f. 45.

\section{O oficial de pedreiro Antônio Mendes da Cunha e sua arquitetura}

Antônio Mendes da Cunha, artifice português residente na Capitania do Ceará, fora acusado de bigamia em processo da Santa Inquisição portuguesa, sob o Processo n 6.274, no ano de 1761.208 De acordo com as atas do inquérito, o oficial de pedreiro nasceu por volta do ano de 1720 na freguesia de Santa Marinha de Linhares, Conselho de Coura, Arcebispado de Braga, sendo filho adulterino do também oficial de pedreiro Antônio Barbosa com Fermiana Mendes da Cunha (Figura 47).

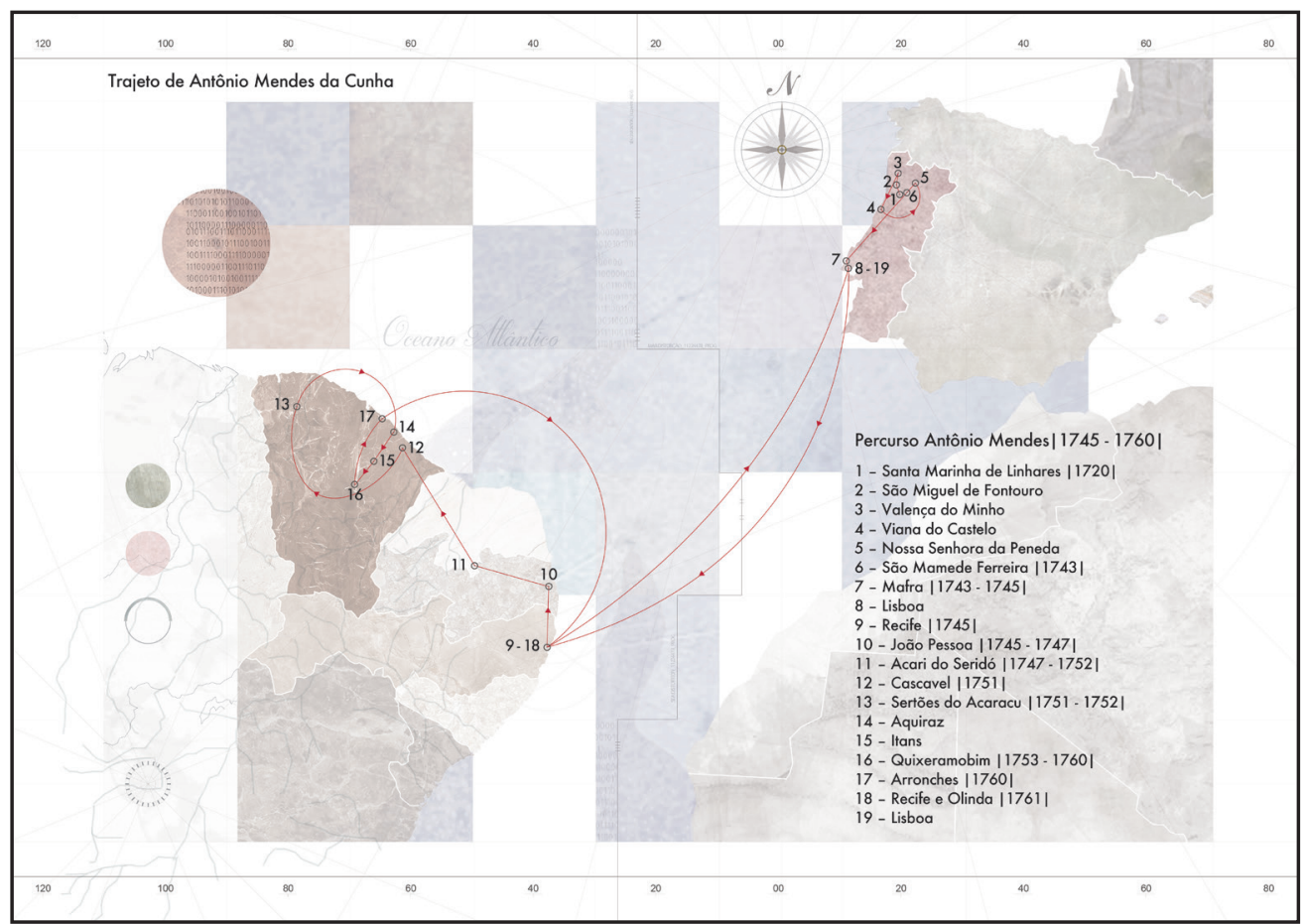

Figura 47 - Trajeto de Antônio Mendes da Cunha. Fonte: Cartografia retrospectiva elaborada pelos autores com base nos dados do Processo n 5.257 (1761). ${ }^{209}$

Aos 20 anos, por ocasião de ser remetido compulsoriamente ao Porto e, de lá, ao Brasil, foge para Viana do Castelo, onde, em "Barrozo e arrabalde da Senhora da Peneda, |vai| trabalhando pelo seo officio de pedreyro junto com seu cunhado Luis de Brito". ${ }^{210} \mathrm{Na}$ ocasião, achava-se em construção o santuário barroco da referida invocação mariana. Em 1743, de volta a sua aldeia, casa-se. Após uma "vida marital de nove ou dez mezes", 211 "se passou para Lisboa a trabalhar junto a Mafra", ${ }^{212}$ "ganhando a vida pelo seu ofício [...] aonde se demorou por dous anos". ${ }^{213}$

Antônio Mendes da Cunha certamente não ficou alheio à atmosfera da construção do monumental Palácio de Mafra. A obra joanina seguramente forjou parte 
das influências trazidas pelo pedreiro quando de seu deslocamento para os sertões do Brasil. Segundo Caldas, "a obra de Mafra terá tido sua influência já que deu emprego, livre ou forçado, a toda uma hierarquia que ia do grande empreiteiro (os Garbo) ao mais humilde servente", passando "pelos subempreiteiros e pelas diferentes ordens de pedreiros e profissões afins". Até os "estratos mais baixos dessa complexa pirâmide tinham os seus hábitos, os seus tiques, um conhecimento mais restrito adquirido em obra e transmitido de geração em geração antes, durante e depois de Mafra". ${ }^{214}$ Dentro do contexto português, a obra-ateliê de Mafra foi incontestável laboratório de síntese das mais diversas influências locais e externas, favorecendo a formação e o aperfeiçoamento de toda uma cadeia de profissionais ligados ao métier da construção. Configurou um polo indutor de difusão técnica e formal de novas ideias, as quais certamente alcançaram os longínquos horizontes dos sertões do Ceará, transmitidas mediante a circulação de artífices como Mendes da Cunha.

Findo o trabalho de dois anos em Mafra, Antônio Mendes da Cunha "se auzentou para a Cidade de Lisboa embarcando na frotta de quarenta e cinco | 1745 | para o Porto de Pernambuco |Recife|". ${ }^{215}$ Começa aí sua trajetória pelos sertões do Brasil, disseminando, no curso pendular de seu ofício, uma produção arquitetônica urdida a partir da mescla cultural decantada nos muitos destinos em que operou, tendo edificado pelo menos cinco igrejas nos sertões cearenses e potiguares.

Após o desembarque no Recife, onde se demorou apenas dois dias, deslocou-se para a "Cidade da Parayba onde assistio dous anos pouco mais ou menos". 216 Desse período em João Pessoa, ainda não se conhece nada de sua produção. Seguindo o rumo leste, o pedreiro Mendes da Cunha estabeleceu-se no sertão do Seridó potiguar, entre 1747 e 1751, na sesmaria do Acari, propriedade de seu tio, um reinol emigrado anos antes para o Brasil, "onde the fez huá Capela no Sitio Acary" (Figura 48). ${ }^{217}$

A ermida apresenta o partido clássico das capelas rurais brasileiras, sendo composta por nave, capela-mor e sacristia lateral - espaços cujas elevações se articulam em movimentada volumetria, de modo que cada setor configura um sólido em altura diferente. A fachada principal tem composição deveras solene, pouco movimentada em comparação àquelas de filiação rococó. Consiste na marcação bem definida de uma proporção quadrada por meio do uso de dois pesados cunhais que sustêm uma grossa cornija retilínea - não fosse uma sutil elevação de seu ponto junto ao capitel dos cunhais -, sobre a qual repousa um frontão recortado em volutas, ornamentado por rosáceas vegetalistas e uma indefectível vieira estilizada ao centro, que será utilizada em outra obra de sua autoria. As envasaduras caracterizam-se pela distribuição em "V": há uma porta central no nível térreo, encimada por duas janelas de coro, num arranjo resultante do prolongamento de linhas imaginarias que partem dos vértices superiores do quadrilátero da fachada em direção ao ponto médio de sua base. 
218. Ibid., f. 45-45v.

219. Ibid., f. 7, $24 v$ e $22 v$.

Figura 48 - Capela de Nossa Senhora da Guia, de Acari, Rio Grande do Norte. Fonte: Acervo Digital do Iphan.

Figura 49 - Capela de Nossa Senhora da Conceição, em Patriarca, Sobral, Ceará. Foto: Ramiro Teles, 2018.
Em 1751, Antônio Mendes da Cunha partiu para o Ceará. Após um ano no lugar "do Cascavel Comarca de Siará", ,18 seguiu para os "Certoens do Acaracu, [...] na freyguezia de Nossa Senhora da Conceisam do Acaracú, em caza de seos primos o Coronel Domingos da Cunha Linhares", colono português e criador de gado. No entorno da casa de fazenda, "usando do seu officio de pedreiro", ergueu uma ermida dedicada à Virgem da Conceição (Figura 49). ${ }^{219}$
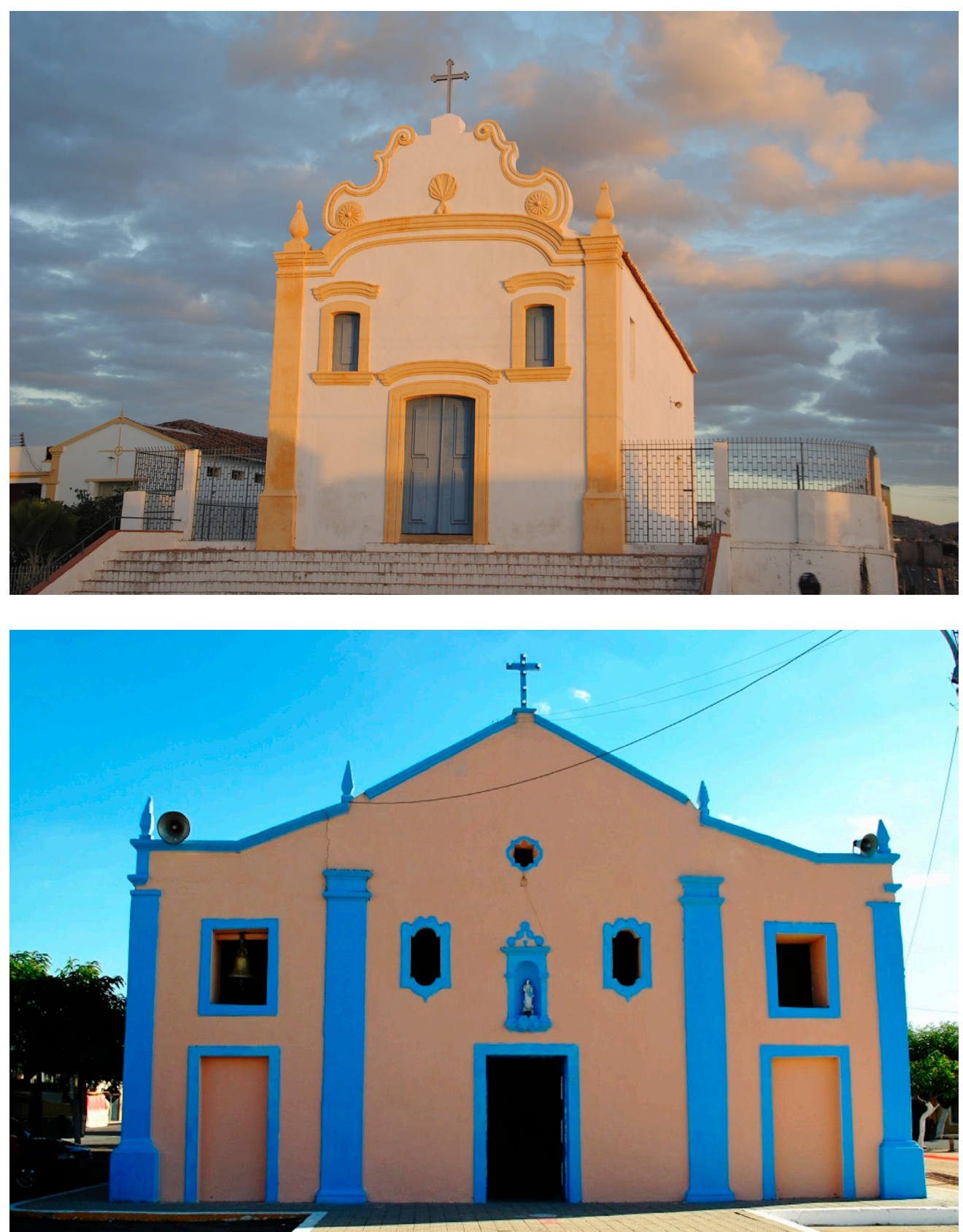
No corpo central, porção primitiva da capela, percebe-se grande sobriedade de formas, numa composição bastante ortodoxa, desprovida de decorativismo, não fosse o nicho renascentista em cantaria. $\bigcirc$ uso de pedra aparelhada também ocorreu nas janelas de coro, com perfilaturas pouco usuais em sua verga e peitoril, cujo desenho é idêntico ao da igreja paroquial de Sapardos, termo de Viana do Castelo, por onde circulara Mendes da Cunha.

Na ocasião em que se encontrava na Fazenda São José, Mendes da Cunha convida seu primo Pedro da Cunha, também pedreiro, para acompanhá-lo a "trabalhar na Villa dos Aquiras Ina igrejal dos Reverendos Padres da Companhia". ${ }^{220} \bigcirc$ artífice fora contratado para trabalhar na construção da lgreja de Nossa Senhora do Bom Sucesso, do Real Colégio dos Jesuítas, concluída em 1753. O conjunto jesuítico foi alienado e demolido na década de 1850, restando apenas ruínas da capela-mor da ermida (Figura 50).

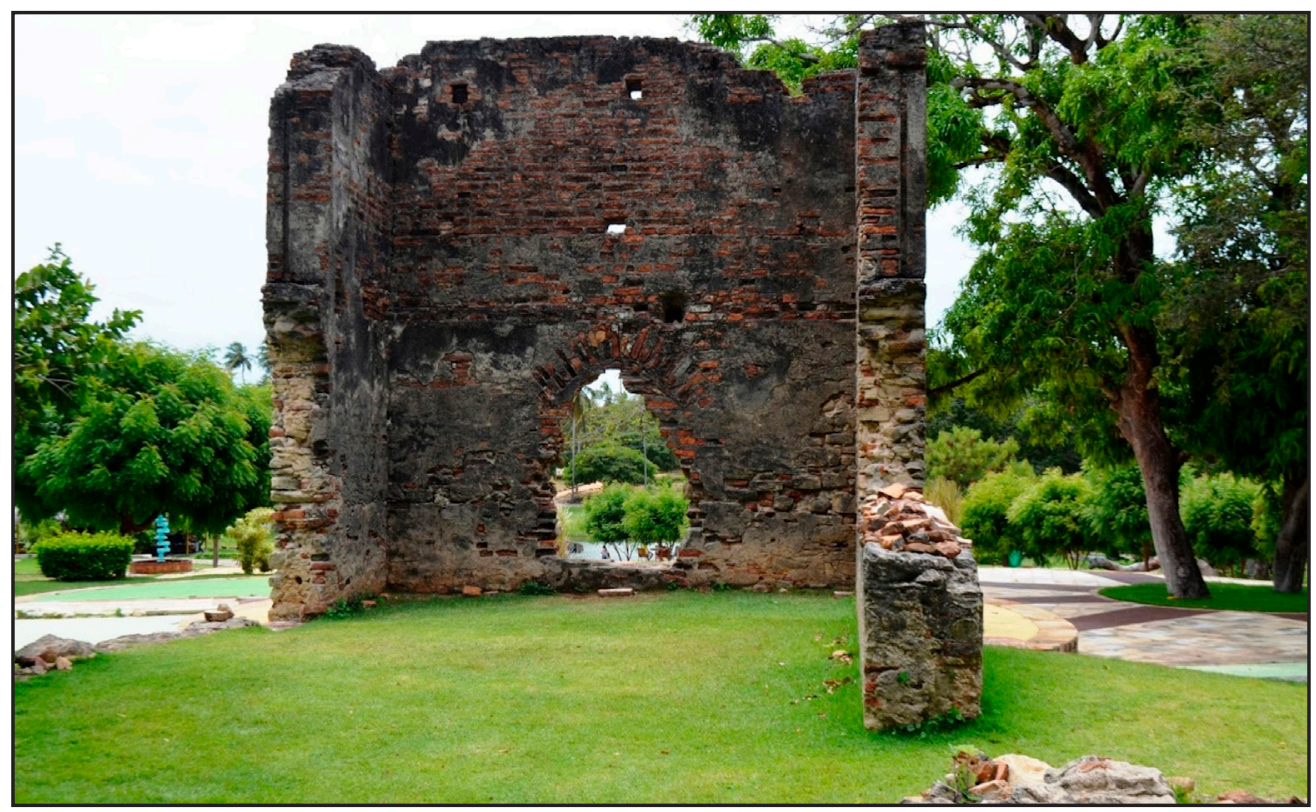

Não se conhecem registros iconográficos que nos permitam comparar essa obra às outras de Mendes da Cunha, exceto pela breve descrição do naturalista Freire Alemão, que afirma que "a igreja era de boas proporções, com paredes de pedra e cal, portados de cantaria e adornos em relevo - tem a era de 1753".221

Deixando Aquiraz, o artífice subiu a ribeira do Rio Choró, contornou as faldas do Maciço de Baturité e passou a trabalhar no "sítio das Itans, em huma Capella do Capitam João de Freytas de Araújo". 222 A pequena ermida é um testemunho precioso de como se processava a integração entre as artes decorativas e a arquitetura dos sertões (Figuras 51 e 52).
220. Ibid., f. 7 .

221. Alemão, op. cit., p. 39-40.

222. Processo de António Mendes..., op. cit., f. 7.

Figura 50 - Ruínas da Capela de Nossa Senhora do Bom Sucesso, do Real Hospício dos Jesuítas, em Aquiraz, Ceará. Foto: Ramiro Teles, 2018. 
Figura 51 - Capela de Nossa Senhora da Conceição, de Itans, Ceará. Foto: Ramiro Teles, 2018.

Figura 52 - Capela de Nossa Senhora da Conceição, de ltans, Ceará. Foto: Ramiro Teles, 2018.
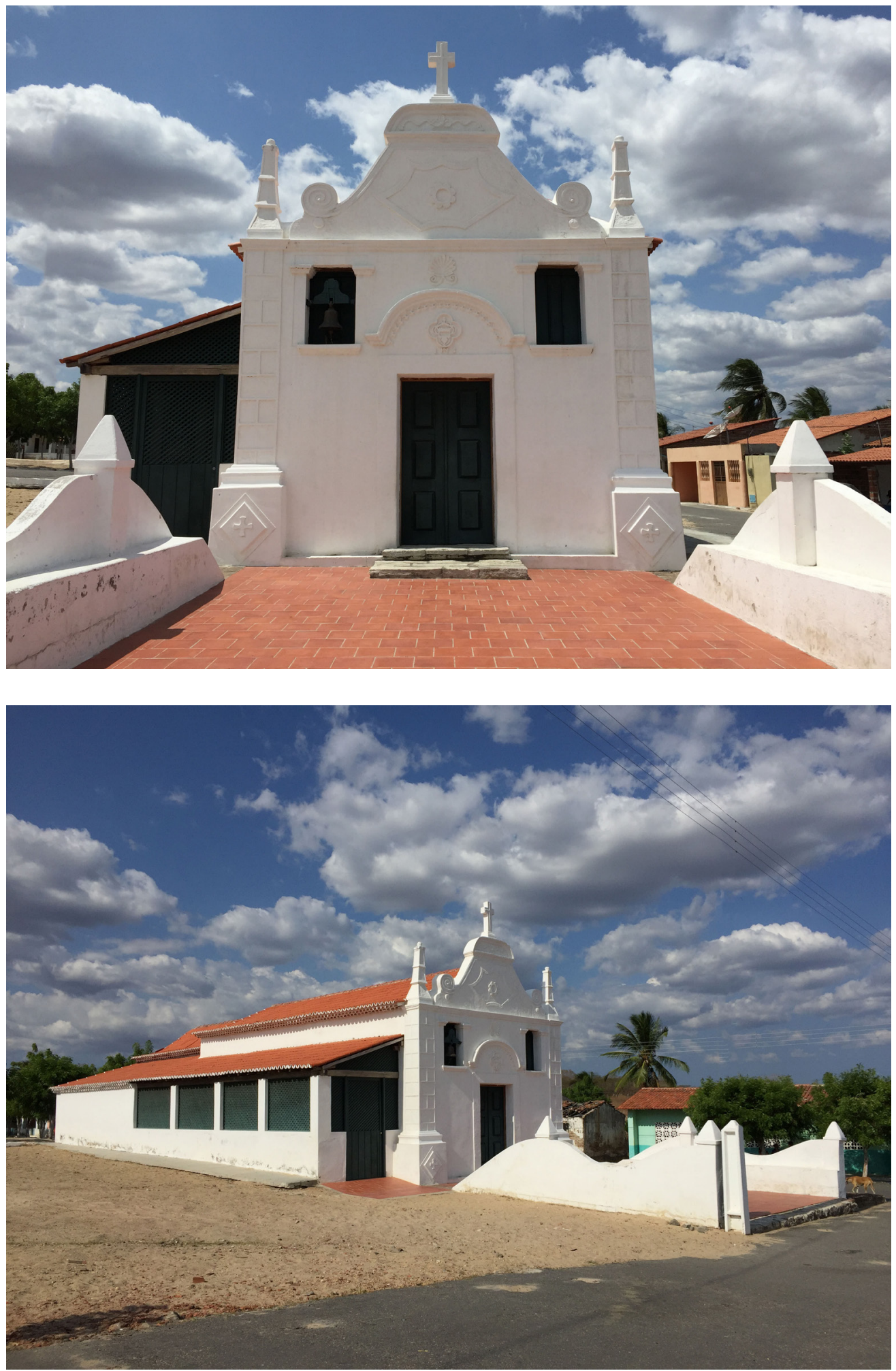
Sobre essa capela, nos detivemos no tópico dedicado à pintura. Suas proporções e medidas são muito semelhantes àquelas da capela erguida no Acaraú para seu primo, tanto que suas plantas chegam a coincidir, se superpostas.

Acima da portada de acesso ao interior da capela de ltans, há um brasão com a insígnia jesuítica IHS - lesus Hominum Salvator. Mendes da Cunha havia acabado de chegar de Aquiraz, onde edificara a igreja do colégio jesuítico e, ao chegar a ltans, a fim de enriquecer a decoração da capela do fazendeiro sertanejo, não hesitou em aplicar ali aquela insígnia que deve ter conhecido a partir de gravuras apresentadas pelos padres da Companhia de Jesus. A referência é uma chave para compreender como cada obra e contexto influenciavam as subsequentes e se tornavam acervo de referências sub-reptícias que iam sendo reproduzidas e reinterpretadas.

Concluída a obra da capela de Itans, o pedreiro bracarense fixa-se na povoação de Santo Antônio de Quixeramobim, "assistindo por tempo de sete anos trabalhando em [...] várias obras que se the offerecião de seu ofício". 223 Em Quixeramobim casa-se novamente, motivo pelo qual foi processado pela Inquisição de Lisboa por bigamia.

Antônio Mendes chega àquela povoação às vésperas de sua elevação à categoria de sede de freguesia, ocasião em que o capitão Antônio Dias Ferreira, português do Porto e proprietário daquelas terras, resolve financiar a edificação da Igreja Matriz de Santo Antônio (Figura 53).

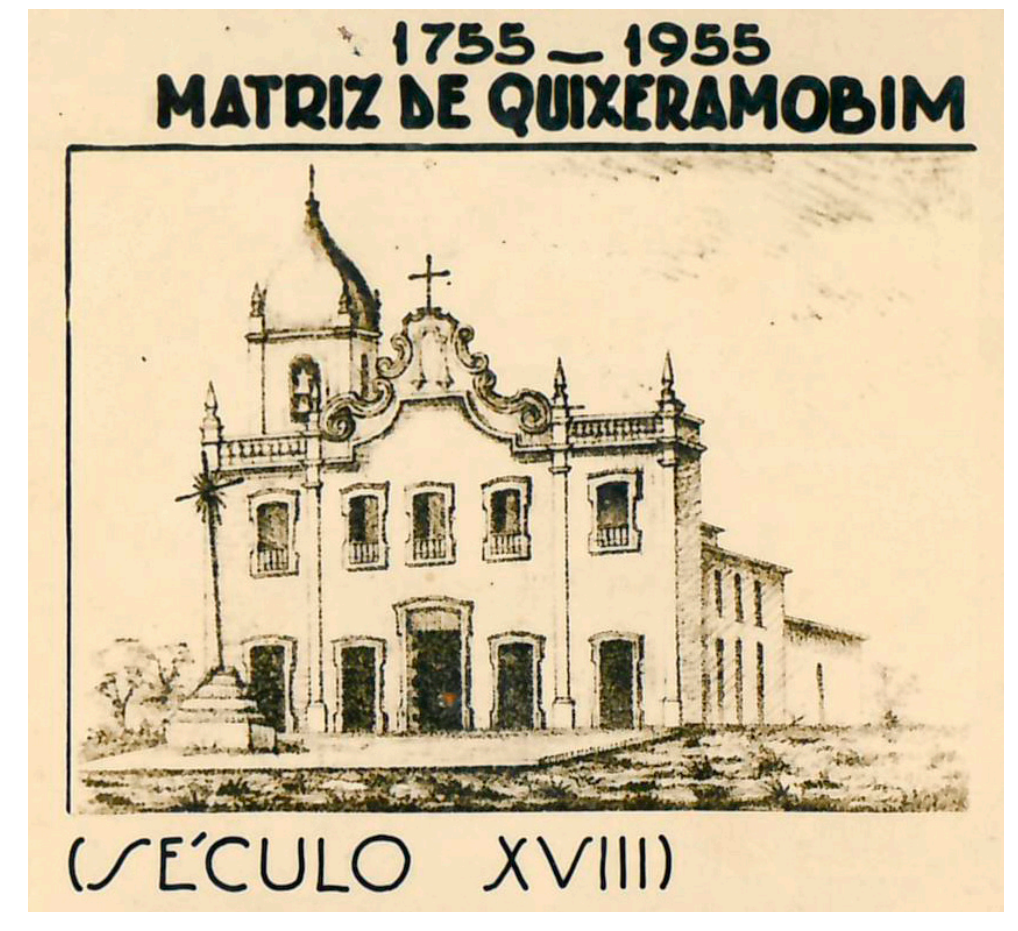

Figura 53 - Igreja de Santo Antônio, de Quixeramobim, Ceará, [s. d.], crayon. Fonte: Acervo de Ismael Pordeus. 
224. Pordeus (1955, p. 193).

225. Ibid., loc. cit.

226. Ibid., loc. cit.
A arrematação da obra coube ao oficial de pedreiro Mendes da Cunha. Em prestação de contas do patrimônio da citada igreja, seu administrador informa textualmente: "Declaro mais o dito Inventariante dever trinta e três mil setecentos e corenta reis por crédito a Antonio Mendes da Cunha, pedreyro". 224

As obras continuariam sob a batuta desse artífice durante cerca de sete anos, até sua prisão pelo Santo Ofício, naquela povoação, em fins de 1760. A partir de então ele deixou dívida pendente com o inventariante do capitão Antônio Dias Ferreira, pois já estava "justo como feriais de Pedreiros e carapinha p.a se fazer a lgreja aos coais já tenho pago adiantado".225

É importante registrar que a concepção final dessa obra esteve mediada entre a práxis e o repertório do dito pedreiro e as instruções objetivas quanto à concepção arquitetônica e decorativa pautadas pelo benfeitor. $\bigcirc$ mecenas da obra, um portuense estabelecido nos sertões de Quixeramobim, era homem sofisticado, proprietário de biblioteca da qual constavam livros como o Flos Sanctorum e o El Governador Christiano. Cosmopolita, estava em constante trânsito entre sua fazenda no Ceará e a praça de Recife, onde foi presidente da Ordem Terceira de São Francisco durante três mandatos, quando gerenciou obras na celebrada Capela Dourada. É totalmente lícito conjecturar que suas ativas relações sociais em Pernambuco resultaram em ideias e ações que se refletiriam fortemente na arquitetura do templo que mandara erguer em sua fazenda.

A evidência cabal dessa circulação de ideias - artísticas, inclusive - vinculadas ao trânsito de homens nos sertões, as quais influenciaram profundamente a produção arquitetônica religiosa setecentista no Ceará, pode ser extraída do testemunho do próprio capitão Dias Ferreira. Em seu testamento, o benfeitor deixa claras orientações a respeito dos aspectos formais do frontispício de sua igreja, bem como instruções quanto à decoração interna do templo. A arquitetura deveria ser "de pedra e cal grande bastante e com três arcos no frontespicio", com "dois altares culatarais hu da pte. do evangelho para Nosa Senhora do Rozario, e dautra pte. hu para hu Santo Christo que se mandara vir feito por bom oficial". E deveria haver mais um "altar abaixo da pte. do evangelho para a Senhora Santa Anna e da outra pte. defronte outro para o Snr. São Miguel Arcanjo, que mandarão fazer ou vir de Portugal por oficiais", que "as fasão com prefeisão não reparando no custo, e os altares bem ornados". 226

Ainda perseguindo a hipótese da circulação de ideias orquestradas pelo patrocinador, o capitão Dias Ferreira, e concretizadas pelas mãos do pedreiro Antônio Mendes da Cunha, uma análise mais totalizante da frontaria da igreja de Quixeramobim revela a sua aproximação com o desenho da fachada da lgreja do Convento do Carmo, em Recife (Figura 54). É nítida a semelhança dos elementos decorativos nas 
fachadas das duas edificações. Ambas apresentam a mesma cornija movimentada em curvas ascendentes, interligadas por segmentos retos que, ao avançar dentro dos domínios do frontão, amparam um pequeno nicho ladeado simetricamente por dois pares de volutas recortadas e contracurvadas de desenho indiscutivelmente similar.

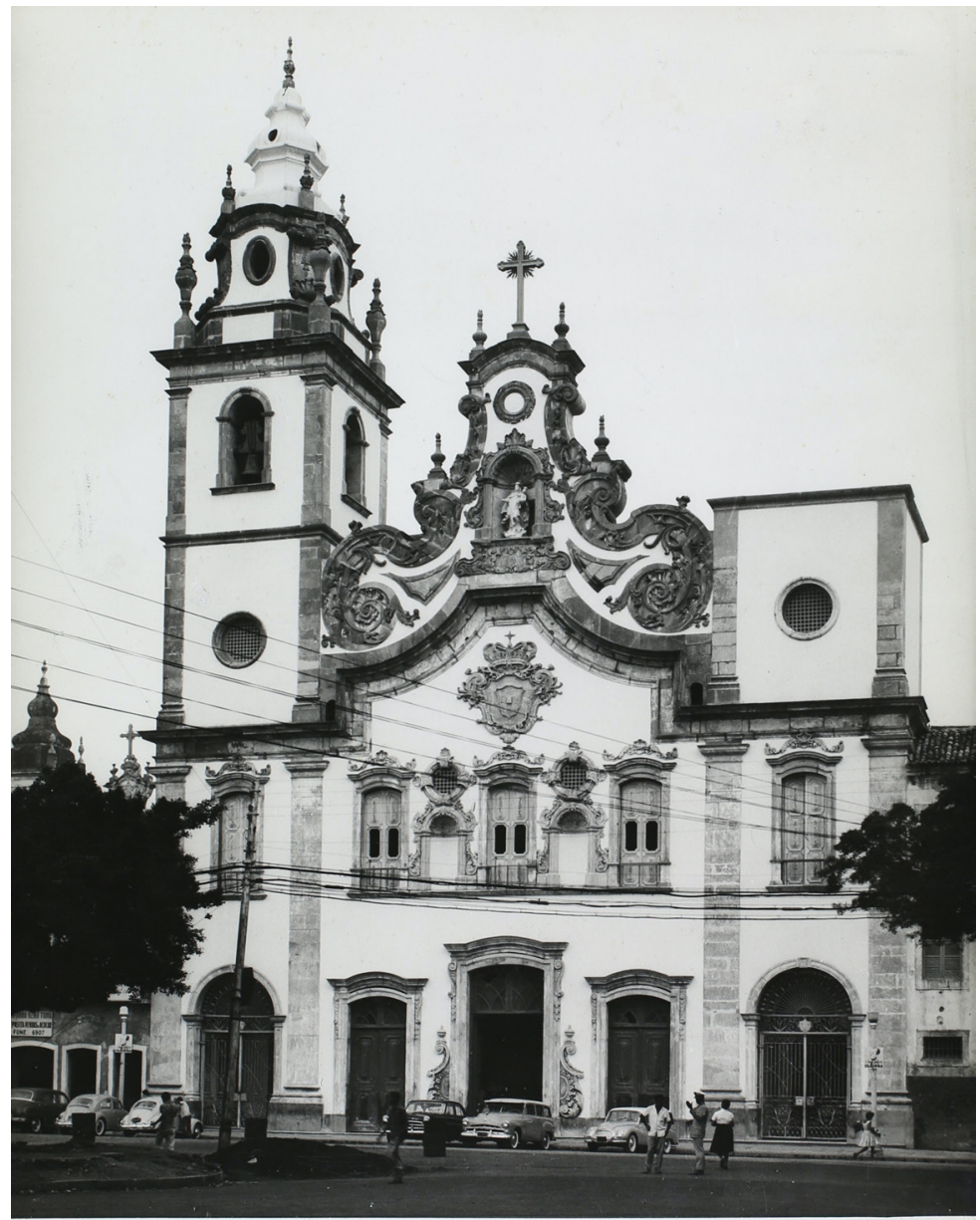

Preso em Quixeramobim, em 1761, o pedreiro Antônio Mendes foi remetido a Recife, de onde embarcou rumo a Lisboa no navio Nossa Senhora de Nazareth. ${ }^{227}$ Foi julgado em auto de fé no Claustro do Convento de São Domingos, em 20 de setembro de 1762, e condenado a uma pena de cinco anos de trabalho forçado nas "Galés de Sua Majestade". 228 Uma leitura detida do processo de Antônio Mendes junto ao Tribunal do Santo Ofício rendeu-nos, ainda, uma preciosa informação para a descoberta de mais um artífice pedreiro que circulara pelo Ceará edificando igrejas: o pernambucano João Pereira.
Figura 54 - Igreja do Convento do Carmo, de Recife, Pernambuco. Foto: Ramiro Teles, 2018.
227. Processo de António Mendes..., op. cit., f. 14.

228. Ibid., f. $69 \mathrm{v}$. 
229. Ibid., f. 14.

230. Castro (2014, p. 28). O autor ressalta a relação formal entre a fachada da Igreja Matriz de Nossa Senhora do Rosário dos Homens Brancos e as igrejas setecentistas pernambucanas.

231. Sobre esse e outros registros iconográficos do Ceará oitocentista, cf. Beserra (2016).

\section{O mestre pedreiro João Pereira e a lgreja Matriz de Aracati}

Na instrução da peça acusatória do artífice Antônio Mendes, foi arrolada uma testemunha, seu colega de profissão, o pernambucano João Pereira. $\bigcirc$ inquisidor do Santo Ofício qualifica a testemunha como "official de pedreyro, solteiro, natural de Pernambuco e morador na Villa do Aracaty". 229

Da década de 1760, período do testemunho, só havia duas obras públicas de maior monta que pudessem atrair artífices construtores para aquela Vila de Santa Cruz do Aracati: a Casa de Câmara e Cadeia, de cuja obra não se conhece documento administrativo, e a Igreja Matriz de Nossa Senhora do Rosário dos Homens Brancos, à qual sempre se atribuíram influxos de influência do barroco pernambucano. ${ }^{230} \mathrm{~A}$ primeira representação conhecida desse edifício é a aquarela de José dos Reis Carvalho, de 1859 (Figura 55). ${ }^{231}$

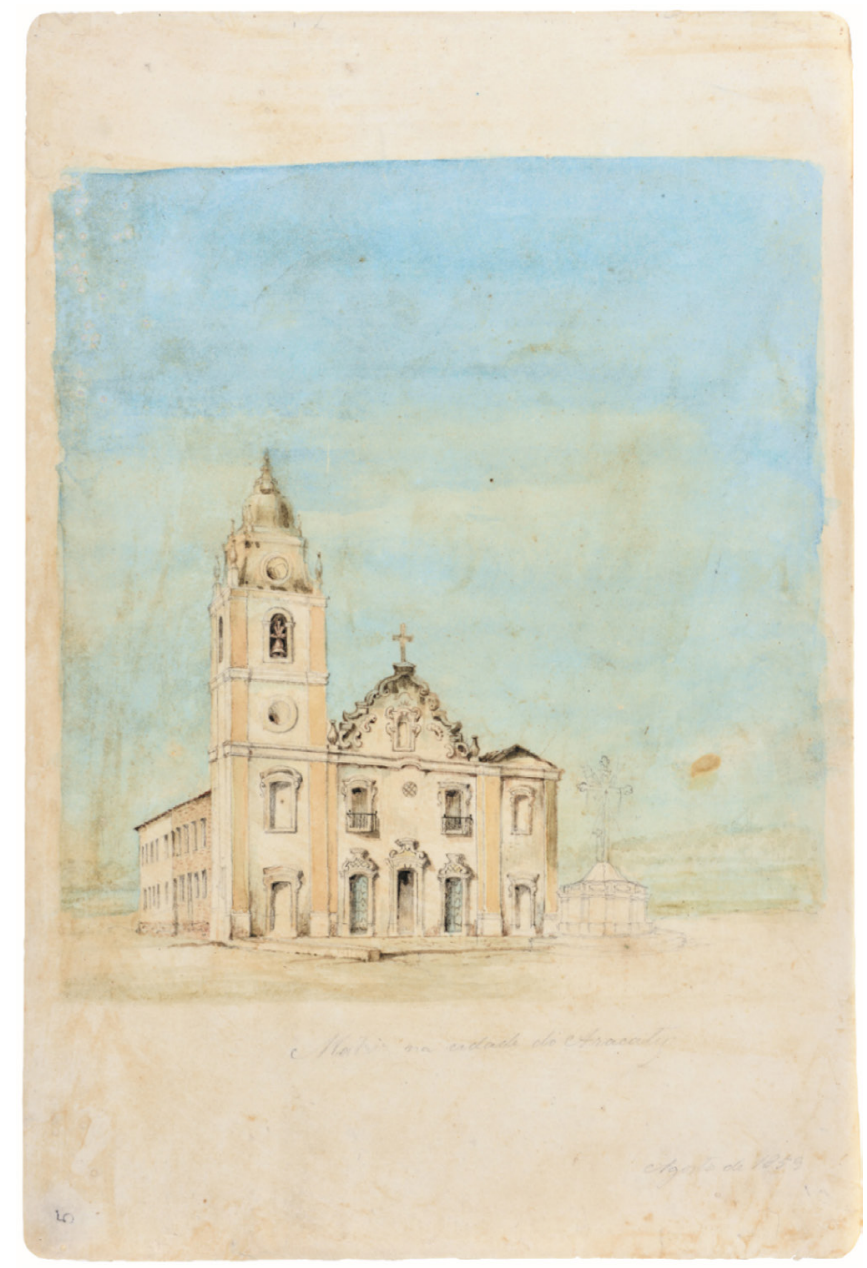

Figura 55 - José dos Reis Carvalho. Matriz na cidade do Aracaty, agosto de 1859, 1859, aquarela e crayon. Fonte: Coleção do Museu His tórico Nacional. Reprodução: Paulo Schevensthul. 
No registro da Receyta e das Despezas das obras da Capella de Nossa Sr. ${ }^{a}$ do Rozário do Porto dos Barcos do Aracaty, ${ }^{232}$ aberto em 1747, depreendese que, desde 1745, o administrador da capela vinha angariando fundos para sua reedificação e para outras despesas. A primeira capela, erguida em 1728, já estava bastante danificada por conta das aluviões do Rio Jaguaribe. ${ }^{233}$ Devido aos inconvenientes para o sepultamento dos mortos na igreja antiga, os administradores locais obtiveram do cabildo de Olinda "provizam para ereçam da nova Igreja para efeito de se enterrarem os mortos pella pouca capacidade que tem a lgreja velha". ${ }^{234}$ Obtida a licença, intensificou-se o recolhimento de donativos para a reconstrução da Igreja, somados aos dízimos impostos às oficinas de charque. ${ }^{235}$ Em 1756, foi lançada sua "prymeira pedra", ocasião solene em que se receberam 89 mil réis de doação para as obras. ${ }^{236}$

No rol de despesas desse ano, denominado Esmollas que se tem tirado e mais Receyta da obra da Capella de Nossa Sr. ${ }^{a}$ do Rozário que o P.e José Lopes de Lima administrou, apareceu, pela primeira vez, o nome do "Me. Pedreyro João Per. a da Sylva", ${ }^{237}$ o official pernambucano que depusera no processo do outro artífice preso pelo Santo Ofício, Antônio Mendes da Cunha. Encadeiam-se, em definitivo, as supostas nuances plásticas de filiação pernambucana da fachada da igreja em questão (Figura 56) e a naturalidade de seu executor.

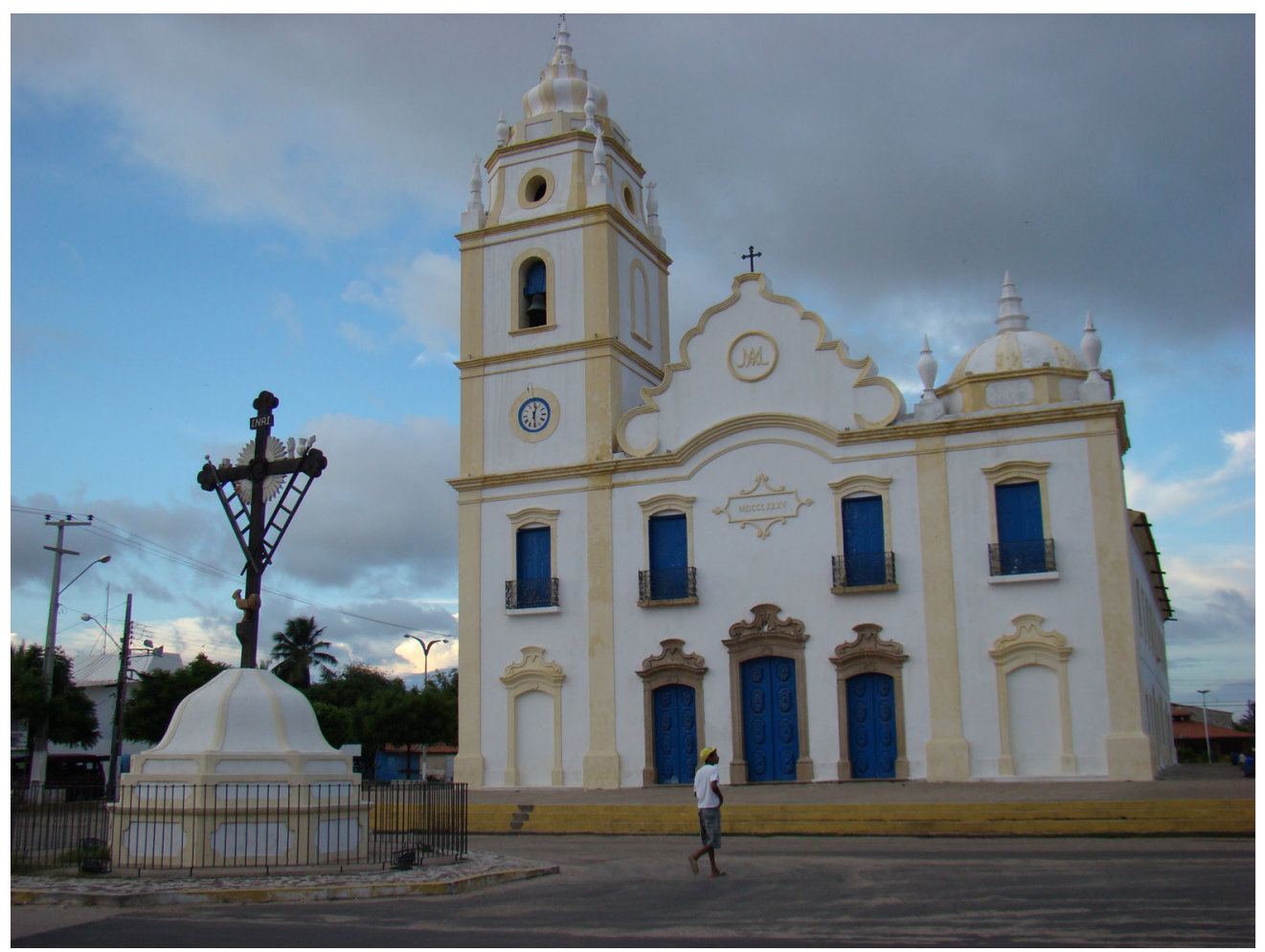

232. Livro de Batizados da Freguesia... (1793-1796).

233. Santos (1918, p. 308).

234. Livro de Batizados da Freguesia..., op. cit., f. 6-6v.

235. Sobre as oficinas de charque no Ceará, cf. Girão (1984), Jucá Neto (2012b) e Nobre (1977).

236. Livro de Batizados da Freguesia..., op. cit., f. 3.

237. Ibid., loc. cit.
Figura 56 - Igreja de Nossa Senhora do Rosário dos Homens Brancos, de Aracati, Ceará (1756-1769). Foto: Ramiro Teles, 2018. 
238. Ibid., f. 36-36v.

239. Livro de Casamentos da Freguesia... (1797-1807, f. $58-58 v$ ).

240. Livro de Batizados da Freguesia..., op. cit., f. 36v.

241. Ibid., f. 3-4v.

242. Livro de Casamentos da Freguesia..., op. cit., f. 58v.

243. Ibid., f. 57-57v.
Ainda em 1756, na ocasião de nova inspeção do visitador de Olinda, o frei carmelita Manoel de Jesus Maria, parte do material já estava adquirido, bem como existiam reservas para o pagamento dos oficiais pedreiros. $\bigcirc$ capítulo da visita recomenda "que the dê logo princípio com os materiais que ahy se acharem e fazendo conduzir a cal [...] e passarâ os bilhetes e letras, p. ${ }^{a}$ se pagar aos oficiais e p. ${ }^{a}$ as mais couzas que carecer a ditta obra". ${ }^{238}$ Com exceção dos materiais mais ordinários, extraídos e beneficiados na própria terra, tais como tijolos, cal, pedra e saibro, os demais, que exigiam um nível maior de especialização técnica para sua produção, vinham de Pernambuco, além de manufaturados como sedas, tafetás, bretanhas, vinho, farinha do reino para hóstias e outras mercadorias para uso cotidiano das missas. De Pernambuco, vieram a "madr. ${ }^{a}$ p. a Capella Mor", "2 duzias de taboado amarêllo", "1 2 cayxeyras de amarêllo p. a portas", "600 pregos caibrares" e "1.500 ripares e assoalhares". 239

A recomendação do visitador prossegue proibindo a aplicação de recursos na conservação da igreja velha, já muito arruinada, devendo-se empregá-los integralmente na construção da nova igreja, na qual trabalhava o mestre João Pereira, "porque som..$^{\text {te }}$ a Capella-Mor acomodarâ mais gente de que toda a velha"240 - o que dá a ideia de que o plano e risco arquitetônico já parecia estar definido e em execução. Entre 1757 e 1759, os trabalhos prosseguiam em ritmo acelerado, a julgar pelo frequente dispêndio de receita para pagamento de "pedreyros e trabalhadores" e pelo movimento e agenciamento de materiais. ${ }^{241}$ Dentre os demais profissionais, sempre citados de forma genérica, surge o nome do Mestre João Pereyra, ocupado do trabalho de pedra, ou com o auxílio de "vermelhos" (indígenas): "P'. dr. ${ }^{\circ}$ que paguei ao M.e João Pr. ${ }^{a}$ p. ${ }^{a}$ enformar a pedra $2 \S 400$ ", e para os "vermelhos p. a ajudarem a enformar 5 dias $1 \S 000$ ". ${ }^{242}$

Pelo menos outros 60 íncolas foram pagos para trabalhar nas obras da Igreja do Rosário dos Brancos de Aracati, dentre os quais se registrou o nome do índio Alexandre e o do índio Manoel. Todos desempenhavam atividades de primeira necessidade no canteiro de obras: conduzir carros, queimar pedras de cal, extrair pedras de alvenaria na pedreira, preparar saibro. Houve ainda o dispêndio de 2.400 réis "Pello que pagou a 6 cabouclos da Parangaba q'. trabalharão na obra". 243 Esses indígenas procediam da Missão da Porangaba, administrada pela Companhia de Jesus desde finais do século XVII, o que enfatiza ainda mais a ideia de uma produção arquitetônica de cariz híbrido, manifestada a partir da circulação de diversos agentes em sua cadeia produtiva e forjada na interação multicultural dos povos formadores da sociedade colonial brasileira. Trata-se de uma igreja no Ceará, destinada exclusivamente aos brancos, administrada por militares portugueses, executada por artífices pernambucanos, 
com auxílio de serventes indígenas missionados por jesuítas, e orquestrada a distância por diretrizes do Bispado de Olinda.

Em 1761, o visitador Veríssimo Rodrigues Rangel, por ocasião do benzimento da capela, anunciou que "a Capella-Mor está acabada de paredes e se trabalha já no corpo da lgreja". ${ }^{244}$ As recomendações não se furtaram de enfatizar a importância de considerar a componente do bom aspecto plástico que a obra deveria ter, de modo que se "procederâ com a maior deligencia e cuydado na ultima perfeyção o complemento da d. . Capella e augumento de tudo o que dicer respeyło a ella". ${ }^{245} \mathrm{~A}$ utilização da igreja velha seria postergada por mais algum tempo. Correndo a obra da igreja nova, ainda no mesmo ano de 1761, os trabalhos do mestre pedreiro João Pereira da Silva sofreriam um revés após a visita pastoral de setembro daquele ano. Os documentos disponíveis não esclarecem sobre a existência de algum risco a seguir ou a cargo de quem estavam as definições do projeto in loco. Fato é que o visitador julgou alguns espaços inadequados quanto à salubridade, funcionalidade e plasticidade, ordenando sua demolição e readequação. Mandou desfazer "o arco da Capella-Mor, que se acha feyto, em razão de ser mt. ${ }^{\circ}$ estreyto, e desforme para a consistência e architetura em q'. se acha o corpo da lgr. ${ }^{a}$ fazendo o mais largo por ter o cruzeyro área p. $^{a}$ isso". Também indicou a reconstrução da "parede do camarim, pondo-a igual com a porta, que se acha feyta [...]", para que a capela-mor ficasse "mais ayroza". Recomendou, ainda, "todo o cuydado e diligência em cobrir a Capella-Mor", e atenção com os paramentos "neces. ${ }^{o s}$ que se pede na nova Pastoral, como sejão ornamentos das quatro cores, confissionarios fechados e pia batismal de pedra fixa com seu aqueducto pelo meyo para consumidouro dos Sanctos Oleos". 246

$\bigcirc$ documento encerra em si diversos aspectos caros ao estudo da arquitetura colonial do Brasil, especialmente dos sertões, que sempre foi tomada por bastardia, sem apuro técnico ou desígnio plástico. Mesmo em cenário econômico pouco favorável, em face da constatação de uma inadequação que implicaria demolição e retrabalho, importava mais ajustar a obra arquitetônica com perfeição ao programa e à consagrada tríade vitruviana do que economizar recursos. Extrai-se das recomendações a preocupação com a solidez - firmitas - do arco, quando apontam sua consistência; o rigor com a funcionalidade - utilitas -, ao considerar a capela-mor pouco "ayroza" ou o "arco estreito"; e o apreço com a beleza - venustas -, quando julgam o arco do cruzeiro "desforme para a architetura" da nave da igreja. Diante da aparente inexistência de desenhos técnicos ou da ausência de engenheiros e arquitetos, fica evidente, outra vez, a prática da execução de obras por meio da orquestração de uma complexa rede de profissionais da construção e da divisão do trabalho, que envolvia operários de diversas origens e formações, pautados por
244. Livro de Batizados da Freguesia..., op. cit., f. 7.

245. Livro de Casamentos da Freguesia..., op. cit., f. 59.

246. Ibid., f. 61-61v. 
247. Santos, op. cit., p. 309.

248. Barroso, op. cit., p. 34. orientações escritas que circulavam em distendidos percursos e eram depuradas a cada novo encontro e revisão, num arco temporal de longa duração, convertendo-se em verdadeiros desenhos por escrito. A Igreja de Nossa Senhora do Rosário dos Homens Brancos da Vila do Aracati foi concluída em 1769. ${ }^{247}$

\section{NOVOS RUMOS PARA A HISTÓRIA DA ARTE E DA ARQUITETURA CEARENSE: O SÉCULO XVIII EM PERSPECTIVA}

O desconhecimento das origens e dos processos formativos da cultura artístico-arquitetônica colonial de regiões remotas nas Capitanias do Norte, distantes do litoral açucareiro, retroalimentou o ciclo histórico de desapreço por parte das pesquisas atinentes à sua história da arte e da arquitetura. Tomando-a por ignoła, enteada da erudição litorânea canavieira, pactuou-se por considerar dispensável o aprofundamento de seu estudo, silenciando-a e esquivando-se de compreender o etos que the deu sentido. Gustavo Barroso, em 1948, já expunha o direcionamento enviesado da historiografia tradicional, repleta de "especialistas dedicados à arte mineira, à arte pernambucana e à arte baiana, todas elas representativas dos esplendores duma riqueza". $\bigcirc$ autor complementa que, no entanto, "até hoje ninguém procurou estudar essa arte escondida, filha da pobreza dos sertões nordestinos e, por isso, talvez, mais cheia de sentimento e de humanidade do que as outras". Em relação ao Ceará, à exceção dos ensaios do arquiteto José Liberal de Castro sobre a arquitetura cearense, o estado da arte desses estudos, sete décadas depois, continua praticamente o mesmo do observado por Gustavo Barroso, pois, ainda hoje, "essa arte sertaneja" é "oficialmente desconhecida e ignorada pelos estudiosos e pelo público", e "pouco se sabe ou mesmo nada se sabe sobre os seus autores". 248

Buscando romper a habitude costumeira das investigações de historiografia da arquitetura brasileira, impõe-se a retomada de arquivos já trabalhados, perscrutar outros negligenciados e alinhavar fontes primárias inauditas dos estudos clássicos de arquitetura para trazer a lume a identidade e a trajetória de vida de engenheiros militares e artífices que estiveram no Ceará - principais agentes da cultura arquitetônica dessa capitania. Esta proposição remonta meandros e interconexões pelos quais circularam os desígnios e as ideias que se fizeram concretude plástica nas Capitanias do Norte.

A análise dessas fontes tem se revelado prolífica e aponta para uma esporádica intervenção proposta por engenheiros militares e, por outro lado, um 
largo raio de atuação de artífices provenientes de Portugal e outras capitanias ao longo do século XVIII. Esses profissionais da construção circularam com desembaraço nos mais diversos pontos entre a metrópole e as Capitanias do Norte, interligando a costa canavieira ao litoral leste-oeste do Brasil e aos locais mais recônditos dos sertões. Alinhavaram caminhos com suas idealizações e intervenções no território e agiram, por vezes, de forma complementar, no limiar entre o acadêmico e a expertise empírica, interceptando conhecimentos que, em comunhão, plasmaram os étimos da nascente arte e arquitetura dos sertões setecentistas.

Os engenheiros e artífices levavam consigo todo um repertório imagético e formalístico que, ao sabor das distâncias, dos múltiplos contextos em que seriam aplicados e mediante as condicionantes e potencialidades oferecidas pelo meio socioeconômico, ia se transfigurando, em largo processo de hibridização.

Se o trânsito dos homens sugere possível interlocução entre artífices e engenheiros, a documentação consultada não deixa explícito o viés e o nível de tal interação. Engenheiros certamente travaram contato direto com os artífices, possivelmente incrementando alguma troca de conhecimento, quando vistoriaram obras das fortificações do litoral norte-sul do Nordeste do Brasil. Também na costa leste-oeste, assim como nos sertões das Capitanias do Norte, eventual contato ocorreu nos lugares de fixação ou passagem dos engenheiros envolvidos na construção e vistoria de obras. Acreditamos que, na maioria das vezes, o trabalho dos mestres pedreiros era apreendido pelo saber da engenharia militar como desacreditado de rigor técnico. Quando Diogo da Sylveyra Vellozo vistoriou a Fortificação de Nossa Senhora da Assumpção, no Ceará, afirmou tratar-se de construção "sem régua nem medida feytos, como obra que não foy desenhada por Engenheyro". ${ }^{249}$ Entre as justificativas da presença de profissionais da engenharia no canteiro de obras das fortificações da Paraíba encontrava-se, segundo carta patente de capitão do engenheiro Luis Xavier Bernardes, evitar os erros dos mestres pedreiros. ${ }^{250}$ Por outro lado, quando um funcionário real vistoriou a igreja de Jeremoabo, construída pelo mestre Araújo Portugal, observou que a obra fora executada com rigor, "com mais perfeiçoens de que mandava a mesma planta". ${ }^{251}$ Esses poucos fragmentos textuais não tornam possível avaliar, de maneira larga, a interação entre os artífices e engenheiros militares nas Capitanias do Norte, em especial no Ceará. Contudo, servem como indicativos da comunicação travada entre os profissionais durante eventuais visitas de acompanhamento de obras, levantamentos cartográficos ou mesmo averiguação dos locais de minas realizadas pelos engenheiros militares.

As edificações remanescentes, especialmente fortificações, igrejas e capelas, revelam pleno domínio das técnicas construtivas, bem como de
249. Carta ( $2^{\mathrm{a}}$ via) do [governador... (1713).

250. Chancelaria Dom João V, op. cit., p. $50 \mathrm{v}$.

251. Relação da Freguesia de S. João... (1757). 
arquétipos compositivos vigentes à época. Reverberam ainda mensagens estéticas provenientes tanto da tratadística militar lusitana como de meneios entre o barroco e o rococó, em vocábulos plásticos nitidamente extraídos e transliterados de léxicos e modelos que circulavam à época. Associados ao repertório mental dos profissionais, tratados, impressos e gravuras, ou mesmo artefatos da cultura material, afluíam aos litorais e sertões do Norte no âmbito de trocas comerciais entre longínquos pontos do ultramar português. Esses homens carregavam consigo ecos estilísticos que, decalcados em novos suportes, foram transculturados e convertidos em engenhosa inovação artística pelas suas mãos. ${ }^{252}$

A atuação e a produção desses engenheiros e artífices, ainda que diversas em termos metodológicos e morfológicos, guardam extrema coesão, posto que mediadas pelo pragmatismo e pelas múltiplas possibilidades físico-socioculturais oferecidas nos litorais e sertões das Capitanias do Norte - em nosso caso, na Capitania do Ceará. Na variedade da dimensão territorial encontramos a chave para o entendimento dessa produção arquitetônica-artística, ou seja, o grande repositório de possibilidades que irá catalisar a hibridização de referenciais subreptícios transplantados por seus autores em movimento. Esse território amplo e diverso possibilita a largueza da dimensão pragmática de suas ações. Os litorais e sertões são a cerzidura que unifica e identifica essa arquitetura, encastoada na terra, ambidestra entre a componente técnico-científica dos engenheiros e a práxis dos artífices, quintessência plasmada entre o permanente trânsito de suas gentes e as múltiplas conexões de suas terras. 


\title{
REFERÊNCIAS
}

\author{
FONTES MANUSCRITAS
}

Arquivo Histórico Ultramarino, Projeto Resgate, Documentos Avulsos do Ceará

CARTA do capitão-mor do Ceará, João Teive Barreto de Menezes, ao Rei [D. João V] sobre a fortaleza que foi feita no tempo da conquista dos sertões. 20 de junho de 1744. Arquivo Histórico Ultramarino, Projeto Resgate, Documentos avulsos do Ceará (1618-1832), AHU_ACL_ CU_017, Cx. 4, Doc. 226. Lisboa: Arquivo Histórico Ultramarino, 1744.

DECRETO do príncipe D. João promovendo Francisco Xavier Torres, sargento-mor da Companhia de Pontoneiros e Artífice do Regimento de Artilharia da Corte, ao posto de primeiro tenente de Artilharia no Ceará, por tempo de oito anos. Queluz, 30 de janeiro de 1799. Arquivo Histórico Ultramarino, Projeto Resgate, Documentos Manuscritos do Ceará, AHU_ACL_CU_006, Cx_006, Cx. 13, Doc. 725 (1). Lisboa: Arquivo Histórico Ultramarino, 1799.

MAPA do estado da Fazenda Real da Capitania do Ceará Grande e suas execuções desde 1725. Ceará, 10 de outubro de 1757. Arquivo Histórico Ultramarino, Projeto Resgate, Documentos Avulsos do Ceará, AHU_CE. Cx. 06, Doc. 35. Lisboa: Arquivo Histórico Ultramarino, 1757.

OFÍCIO do tenente comandante do $1^{\circ}$ Corpo de Artilharia da Vila de Fortaleza, Francisco Xavier Torres, ao [secretário de Estado dos Negócios da Marinha e Ultramar, D. Francisco de Sousa Coutinho], sobre a vistoria feita na fortaleza da referida vila e do reduto de São Luis, na ponta do Mucuripe, bem como sobre a aquisição de trinta peças de artilharia e a necessidade de se construir uma casa de pólvora. Fortaleza, $1^{\circ}$ de janeiro de 1800 . Arquivo Histórico Ultramarino, Projeto Resgate, Documentos Manuscritos do Ceará, AHU_ACL_CU_006, Cx. 13, Doc. 748 (1). Lisboa: Arquivo Histórico Ultramarino, 1800.

REQUERIMENTO do tenente de Artilharia no Ceará, Francisco Xavier Torres, ao [príncipe regente, D. João], a pedir licença para ir ao reino [post. 1801]. Arquivo Histórico Ultramarino, Projeto Resgate, Documentos Manuscritos do Ceará, AHU_ACL_CU_006, Cx. 15, Doc. 887 (1). Lisboa: Arquivo Histórico Ultramarino, [1801].

Arquivo Histórico Ultramarino, Projeto Resgate, Documentos Avulsos de Pernambuco

CARTA ( $2^{\mathrm{a}}$ via) do [governador da Capitania de Pernambuco], Félix José Machado [de Mendonça Eça Castro e Vasconcelos], ao rei [D. João V], sobre a ordem para fortificar aquela capitania, a fim de evitar as invasões dos inimigos. Pernambuco, 15 de setembro de 1713. Arquivo Histórico Ultramarino, Projeto Resgate, Documentos Avulsos de Pernambuco, AHU_ACL_CU_015, Cx. 25, D. 2314. Lisboa: Arquivo Histórico Ultramarino, 1713. 
CARTA do [governador da Capitania de Pernambuco, Conde dos Arcos], D. Marcos José de Noronha e Brito, ao Rei [D. João V], sobre a vistoria feita pelo engenheiro e tenente-general Luis Xavier Bernardes na fortaleza do Ceará e execução da planta da dita fortaleza. Recife, 5 de janeiro de 1747. Anexos: 5 docs. Arquivo Histórico Ultramarino, Projeto Resgate, Documentos Avulsos de Pernambuco, AHU_ACL_CU_015, Cx. 65, D. 5500. Lisboa: Arquivo Histórico Ultramarino, 1747.

CONSULTA do Conselho Ultramarino ao rei D. João V, sobre nomeação de pessoas para o cargo de engenheiro da capitania de Pernambuco, que vagou por falecimento do engenheiro Luis Francisco Pimentel, no qual lugar estava provido o engenheiro Antônio de Aguiar Coelho. Lisboa, 28 de janeiro de 1707. Arquivo Histórico Ultramarino, Projeto Resgate, Documentos Avulsos de Pernambuco, AHU_ACL_CU_015, Cx. 22, D. 2032. Lisboa: Arquivo Histórico Ultramarino, 1707a.

CONSULTA do Conselho Ultramarino ao rei D. João V, sobre o requerimento do Capitão engenheiro Diogo da Silveira Veloso, pedindo ajuda de custo. Anexos: 3 docs. 2023 - Lisboa, 27 de janeiro de 1707. Arquivo Histórico Ultramarino, Projeto Resgate, Documentos Avulsos de Pernambuco, AHU_ACL_CU_015, Cx. 22, D. 2030. Lisboa: Arquivo Histórico Ultramarino, $1707 \mathrm{~b}$.

CONSULTA do Conselho Ultramarino ao rei D. João V, sobre o requerimento do sargentomor de Infantaria e engenheiro da capitania da Paraíba do Norte, Luis Xavier Bernardo, pedindo nomeação para o posto de tenente-general de Artilharia da capitania de Pernambuco. Anexo: 3 docs. Lisboa, 7 de março de 1735. Arquivo Histórico Ultramarino, Projeto Resgate, Documentos Avulsos de Pernambuco, AHU_ACL_CU_015, Cx. 48, D. 4287. Lisboa: Arquivo Histórico Ultramarino, 1735.

PARECER da Junta [de engenheiros do Reino e da Capitania de Pernambuco], Manoel de Azevedo Fortes, Jão Massé, José da Silva Paes e Diogo da Silveira Veloso, ao Rei [D. João V], sobre as obras das fortificações da dita capitania, [Cidadela do Recife] e fortes Brum, Santo Antônio dos Coqueiros, Nazaré e Quarteis de Olinda. 3541 - Lisboa, 17 de novembro de 1729. Arquivo Histórico Ultramarino, Projeto Resgate, Documentos Manuscrito de Pernambuco, AHU_ACL_CU_015, Cx. 39, D. 3541. Lisboa: Arquivo Histórico Ultramarino, 1729.

REQUERIMENTO do tenente de mestre-de-campo general da Infantaria da capitania de Pernambuco Luis Xavier Bernardes, ao rei [D. João V], pedindo consulta para receber o posto de mestre-de-campo de Infantaria, com o exercício da ordem do governador da mesma capitania, [Conde dos Arcos, D. Marcos José de Noronha e Brito], vencendo o soldo correspondente ao posto. [ant. 4 de janeiro de 1747]. Anexos: 3 docs. Arquivo Histórico Ultramarino, Projeto Resgate, Documentos Avulsos de Pernambuco, AHU_ACL_CU_015, Cx. 65. D. 5499. Lisboa: Arquivo Histórico Ultramarino, [1747].

REQUERIMENTO do tenente-general da Artilharia da capitania de Pernambuco, Diogo da Silveira Veloso, ao rei [D. João V], pedindo para juntar este requerimento aos outros papéis que se encontram no Conselho Ultramarino, a fim de receber remuneração de seus serviços para repartir entre seus quatro filhos. Anexos: 14 docs. 5464 - [ant. 31 de outubro de 1746]. Arquivo Histórico Ultramarino, Projeto Resgate, Documentos Manuscritos de Pernambuco, AHU_ACL_CU_015, Cx. 64, D. 5464. Lisboa: Arquivo Histórico Ultramarino, [1746]. 
REQUERIMENTO do tenente general da Artilharia e engenheiro na capitania de Pernambuco, Diogo da Silveira Veloso, ao rei [D. João V], pedindo como ajuda de custo, o soldo dobrado de todo o tempo em que esteve na ilha de Fernando de Noronha, no trabalho de sua fortificação, e na Paraíba onde foi desenhar uma nova fortaleza [ant. 7 de fevereiro de 1739]. Arquivo Histórico Ultramarino, Projeto Resgate, Documentos Manuscritos de Pernambuco, AHU_ACL_CU_015, Cx. 53, D. 4635. Lisboa: Arquivo Histórico Ultramarino, [1739].

Arquivo Histórico Ultramarino, Projeto Resgate, Documentos Avulsos da Bahia

CONSULTA do Conselho Ultramarino ao rei D. João V sobre o pedido do vigário da freguesia de São João de Geremoaba, Padre João Coelho de Bessa para ajuda de custo a fim de reedificar a Igreja Matriz. Lisboa, $1^{\circ}$ de fevereiro de 1736. Arquivo Histórico Ultramarino, Projeto Resgate, Documentos Avulsos da Bahia, AHU_ACL_CU_005, Cx. 54, Doc. 4676. Lisboa: Arquivo Histórico Ultramarino, 1736.

Arquivo Histórico Ultramarino, Projeto Resgate, Documentos da Bahia, Eduardo de Castro e Almeida (1613-1807)

RELAÇÃO da Freguesia de S. João Babtista do Jerimuabo do Certão de Cima do Arcebispado da Bahia, pelo padre Januário José de Sousa Pereira, Parocho encommendado da mesma freguezia. São João do Jerimuabo, 29 de dezembro de 1757. Arquivo Histórico Ultramarino, Projeto Resgate, Documentos da Bahia, Eduardo de Castro Almeida (1613-1807), AHU_BA, Cx. 15, Doc. 2717. Lisboa: Arquivo Histórico Ultramarino, 1757.

Arquivo Histórico Ultramarino, Projeto Resgate, Códice

LIVRO de registro de provisões régias dirigidas a várias entidades de diferentes Capitanias do Brasil. 1 vol. Documentos Manuscritos Códices I (1548-1821). Arquivo Histórico Ultramarino, Projeto Resgate, Códice, AHU_ACL_CU_Cod.261, Cd-13. Lisboa: Arquivo Histórico Ultramarino, 1548-1821.

Arquivo Público Estado do Ceará

OFÍCIO dirigido ao Tenente-Coronel Engenheiro Antonio José da Silva Paulet encarregando-o

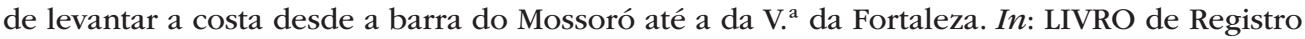
de officios e ordens por este Governo ao [...] gente de guerra e aos chefes, e mais oficiais de Linha e Milícias. 18 de agosto de 1812. Arquivo Público do Estado do Ceará, Livro 33 (Antigo 65 - A), Cx. 10, Série, Governo da Capitania do Ceará aos militares da Capitania, ofícios. Fortaleza: Arquivo Público do Estado do Ceará, 1812.

OFÍCIO ao Tenente-Coronel Antonio José da Silva Paulet sobre a arremessa da Carta Marinha da Costa desta capitania p. ${ }^{\text {a }}$ Secretaria de Estado dos Neg. ${ }^{\text {os }}$ Estrangeiros, e da Guerra. 6 de abril de 1816. Arquivo Público do Estado do Ceará, Livro 35 (Antigo 89), Cx. 10, Série, Governo da Capitania do Ceará aos militares da Capitania, ofícios. Fortaleza: Arquivo Público do Estado do Ceará, 1816. 
CHANCELARIA Dom João V. Arquivo Nacional da Torre do Tombo, Cota atual: Chancelaria de D. João V, livro 45, Código de referência: PT/TT/CHR/T/001/0045. Lisboa: Arquivo Nacional da Torre do Tombo, 1716.

PROCESSO de António Correia de Araújo Portugal. Data: 9 de agosto de 1759 a 15 de novembro de 1766. Arquivo Nacional da Torre do Tombo, Inquisição de Lisboa, Processos 1526-1821, Código de Referência: PT/TT/TSO-IL/028/06269. Lisboa: Arquivo Nacional da Torre do Tombo, 1759-1766.

PROCESSO de António Mendes da Cunha. Data: 14 de maio de 1761 a 20 de setembro de 1761 . Arquivo Nacional da Torre do Tombo, Inquisição de Lisboa, Processos 1526-1821, Código de Referência: PT/TT/TSO-IL/028/06274. Lisboa: Arquivo Nacional da Torre do Tombo, 1761.

Arquivo da Cúria Diocesana de Iguatu (Ceará, Brasil)

LIVRO no 4 da Freguesia de Nossa Senhora da Expectação de Icó. Batizados 1763-1783. Iguatu: Arquivo da Cúria Diocesana de Iguatu, 1763-1783.

LIVRO n ${ }^{\circ} 19$ da Freguesia de Nossa Senhora da Expectação do Icó. Óbitos. 1777-1800. Iguatu: Arquivo da Cúria Diocesana de Iguatu, 1777-1800.

Arquivo da Cúria Diocesana de Limoeiro do Norte (Ceará, Brasil)

LIVRO de Batizados da Freguesia de Aracati, Ano 1793-1796. Limoeiro do Norte: Arquivo da Cúria Diocesana de Limoeiro do Norte, 1793-1796.

LIVRO de Casamentos da Freguesia de Aracati, Ano 1797-1807. Limoeiro do Norte: Arquivo da Cúria Diocesana de Limoeiro do Norte, 1797-1807.

Instituto do Patrimônio Histórico e Artístico Nacional

RESCALA, João José. Relatório de viagem de João José Rescala [manuscrito]. Instituto do Patrimônio Histórico e Artístico Nacional, Arquivo Noronha Santos. Rio de Janeiro: Iphan, 1941.

LIVROS, ARTIGOS E TESES

ACIOLI, Vera Lúcia C. $A$ identidade da beleza: dicionário de artistas e artífices do século XVI ao XIX em Pernambuco. Recife: Massangana, 2008. 
ALEMÃo, Francisco Freire. Diário de viagem de Francisco Freire Alemão (1859 - 1861). Fortaleza: Fundação Waldemar Alcântara, 2011.

ANDRADE, Margarida Julia Farias de Salles. Fortaleza em perspectiva histórica: poder público e iniciativa privada na apropriação e produção material de cidade (1810-1933). Fortaleza: Fundação Waldemar Alcântara, 2019.

ARRAES, Damião Esdras Araújo. Ecos de um suposto silêncio: paisagem e urbanização dos "certoens" do Norte, c. 1666-1820. 2017. Tese (Doutorado em Arquitetura e Urbanismo) Universidade de São Paulo, São Paulo, 2017.

ARRUDA, José Jobson de Andrade. Os portugueses no Brasil, de colonos a imigrantes: reflexões teóricas. In: ARRUDA, José Jobson de Andrade et al. (orgs.). De colonos a imigrantes: i(e) migração portuguesa para o Brasil. São Paulo: Alameda, 2013. p. 13-20.

BARROSO, Gustavo. A arquitetura dos sertões. O Cruzeiro, Rio de Janeiro, n. 52, p. 22-34, 16 out. 1948.

BESERRA, José Ramiro Teles. Pintura colonial cearense: a relação entre o popular e o erudito nos caixotões da Capela-Mor de São José, em Aquiraz. Imagem Brasileira, Belo Horizonte, $\mathrm{n}$. 7, p. 71-80, 2013.

BESERRA, José Ramiro Teles (org.). Aquarelas e desenhos do Ceará oitocentista: o trabalho de José dos Reis Carvalho na Comissão Científica de Exploração (1859-1861). Fortaleza: Iphan, 2016.

BESERRA, José Ramiro Teles. Matrizes e capelas do Ceará: circularidade e conexões atlânticas: arquitetura e artífices entre os sertões do Norte e Portugal (1700-1820). 2018. Dissertação (Mestrado em Arquitetura e Urbanismo) - Universidade Federal do Ceará, Fortaleza, 2018.

BRAGA, Nilza Licia Xavier Silveira. A emigração portuguesa para o Brasil na segunda metade do século XVIII. Revista Angelus Novus, São Paulo, ano 4, n. 6, p. 95-114, 2013.

BRAGA, Renato. História da Comissão Científica de Exploração. Fortaleza: Sudene, 1982. (Coleção Mossoroense, v. 200).

BUENO, Beatriz Piccolotto Siqueira. Com as mãos sujas de cal e de tintas, homens de múltiplas habilidades: os engenheiros militares e a cartografia da América portuguesa (sécs. XVI-XIX). In: SIMPÓSIO BRASILEIRO DE CARTOGRAFIA HISTÓRICA, 1., 2011, Paraty. Anais [...]. Belo Horizonte: UFMG, 2011a. p. 1-14. Disponível em: <https://bit. ly/3pwjDPQ>. Acesso em: 17 fev. 2021.

BUENO, Beatriz Piccolotto Siqueira. Desenho e desígnio: o Brasil dos engenheiros militares (1500-1822). São Paulo: Edusp, 2011b. 
BUENO, Beatriz Piccolotto Siqueira. Sistema de produção da arquitetura na cidade colonial brasileira: mestres de ofício, "riscos" e "traças". Anais do Museu Paulista, São Paulo, v. 20, n. 1, p. 321-361, 2012.

BUENO, Beatriz Piccolotto Siqueira. Por uma arqueologia da paisagem: mobilidade e enraizamento em perspectiva americana. Labor E Engenho, Campinas, v. 11, n. 3, p. 242-262, 2017.

BURKE, Peter. Hibridismo cultural. São Leopoldo: Editora Unisinos, 2003.

CALDAS, João Vieira. A casa rural dos arredores de Lisboa no século XVIII. Porto: Editora Faup, 1999.

CARITA, Rui. Os engenheiros-mores na gestão de Império: a Provedoria das Obras dos meados do século XVI. In: ARAÚJO, Renata; CARITA, Hélder; ROSSA, Walter (orgs.). Actas do Colóquio Internacional Universo Urbanístico Português, 1415-1822. Lisboa: Comissão Nacional para as Comemorações dos Descobrimentos Portugueses, 2001. p. 393-405.

CASTRO, José Liberal de. Notas relativas à arquitetura antiga no Ceará. 1980. Tese (LivreDocência) - Universidade Federal do Ceará, Fortaleza, 1980.

CASTRO, José Liberal de. Cartografia cearense no Arquivo Histórico do Exército. Revista do Instituto do Ceará, Fortaleza, t. 111, p. 9-79, 1997.

CASTRO, José Liberal de. Urbanização pombalina no Ceará: a paisagem da vila de Montemoro-Novo d'América. Revista do Instituto do Ceará, Fortaleza, t. 113, p. 35-81, 1999.

CASTRO, José Liberal de. Igreja Matriz de Viçosa do Ceará: arquitetura e pintura de forro. Fortaleza: Iphan, 2001.

CASTRO, José Liberal de. Fortaleza de Nossa Senhora da Assunção da Capitania do Ceará Grande: pleito de tombamento. Fortaleza: [s. n.], 2005. Cópia xerocada do acervo particular de José Liberal de Castro.

CASTRO, José Liberal de. Apresentação. In: JUCÁ NETO, Clovis Ramiro. Primórdios da urbanização do Ceará. Fortaleza: UFC, 2012a. p. 15-21.

CASTRO, José Liberal de. Bicentenário da Fortaleza de Nossa Senhora da Assunção: o caso singular de uma obra de arquitetura militar com função simbólica. Revista do Instituto do Ceará, Fortaleza, ano 126, p. 9-72, 2012b.

CASTRO, José Liberal de. Arquitetura no Ceará: o século XIX e algumas antecedências. Revista do Instituto do Ceará, Fortaleza, t. 128, p. 9-68, 2014.

CASTRO, José Liberal de. Cartografia cearense antiga na Biblioteca Nacional. Revista do Instituto do Ceará, Fortaleza, ano 130, p. 47-100, 2016. 
CASTRO, José Liberal de. Cartografia cearense no Arquivo Nacional. Revista do Instituto do Ceará, Fortaleza, ano 132. p. 7-46, 2018.

DANGELO, André Guilherme Dornelles. A cultura arquitetônica em Minas Gerais e seus antecedentes em Portugal e na Europa: arquitetos, mestres de obras e construtores e o trânsito de cultura na produção da arquitetura religiosa nas Minas Gerais setecentistas. 2006. Tese (Doutorado em História Social da Cultura) - Universidade Federal de Minas Gerais, Belo Horizonte, 2006.

DINIZ, Nathália Maria Montenegro. Um sertão entre tantos outros: fazendas de gado nas Ribeiras do Norte. 2013. Tese (Doutorado em Arquitetura e Urbanismo) - Universidade de São Paulo, São Paulo, 2013.

ESTATUTO da Confraria da Imaculada Conceição do Escapulário e das dez Virtudes de Maria Santíssima. Erecta e noticiada com suas próprias Indulgências pelos Religiosos Marianos. Lisboa, 1758.

GIRÃO, Valdelice Carneiro. As oficinas ou charqueadas no Ceará. Fortaleza: Secretaria de Cultura e Desporto, 1984.

GOMES, René Lommez; PAIVA, Eduardo França; SANTOS, Vanicléia Silva (orgs.). O comércio de marfim no mundo atlântico: circulação e produção (séculos XV a XIX). Belo Horizonte: Clio Gestão Cultural e Editora, 2018.

GUTIÉRREZ, Ramon. Transculturação, rupturas e persistências na identidade arquitetônica americana. In: GUTIÉRREZ, Ramon. Arquitetura latino-americana. São Paulo: Nobel, 1989. p. 53-75.

JUCÁ NETO, Clovis Ramiro. Ritual, rigor, pragmatismo: os procedimentos de instalação da Vila de Monte-Mor o Novo da América na Capitania do Ceará. In: ENCONTRO NACIONAL DA ANPUR, 14., 2011, Rio de Janeiro. Anais [...]. Belo Horizonte: Anpur, 2011. p. 1-21.

JUCÁ NETO, Clovis Ramiro. Os primórdios da organização do espaço territorial e da vila cearense: algumas notas. Anais do Museu Paulista, São Paulo, v. 20, n. 1. p. 133-163, $2012 a$.

JUCÁ NETO, Clovis Ramiro. Primórdios da urbanização do Ceará. Fortaleza: UFC, $2012 b$.

JUCÁ NETO, Clovis Ramiro. Salve o Rei!!!. A Vila de Montemor-o-Novo d'América fora instalada na Capitania do Ceará. A formalidade de que manda o novo método. In: MELO, Ana Amélia M. C. de; OLIVEIRA, Irenísia Torres de (orgs). Aproximações, cultura e política. Fortaleza: Expressão Gráfica e Editora, 2013. p. 123-148.

JUCÁ NETO, Clovis Ramiro. Arquitetura religiosa do Ceará e sua relação com o espaço territorial e urbano oitocentista da Província. Cadernos PPG-AU/Faufba, Salvador, ano 12, número especial 11. 2014. p. 195-219. 
JUCÁ NETO, Clovis Ramiro. Desenhando a Capitania do Ceará: a cartografia histórica e a representação do território. In: CAVALCANTE, Maria Juraci Maia et al. (orgs.). Histórias de pedagogia, ciências e religião: discursos e correntes de cá e do além-mar. Fortaleza: Edições UFC, 2016. p. 183-216.

JUCÁ NETO, Clovis Ramiro. Cidade do Icó e arquitetura religiosa: insinuações barrocas nos sertões do Ceará oitocentista. In: FRIDMAN, Fania; GENNARI, Luciana Alem; KRAUSE, Cleandro (orgs.). De cidades e territórios. Rio de Janeiro: PoD, 2019. v. 2, p. 35-48.

JUCÁ NETO, Clovis Ramiro; ANDRADE, Margarida Julia Farias de Salles; PONTE, Alana Figueirêdo. A fixação da Igreja no território cearense durante o século XVIII: algumas notas. Revista Paranoá, Brasília, DF, n. 13, p. 27-36, 2014.

JUCÁ NETO, Clovis Ramiro; GONÇALVES, Adelaide. Arquitetura como extensão do sertão: casa de fazenda setecentista e oitocentista dos Inhamuns no Ceará. Fortaleza: Fundação Waldemar Alcântara, 2019.

KURY, Lorelay (org.). Comissão Científica do Império: 1859-1861. Rio de Janeiro: Andrea Jakobsson Estúdio, 2009.

LIMA, Francisco Augusto de Araújo. Famílias cearenses 7: Ipueiras dos Targinos. Fortaleza: Artes Digitais, 2006.

LIMA, Francisco Augusto de Araújo. Siará Grande: uma província portuguesa no Nordeste Oriental do Brasil: genealogia luso-cearense. Fortaleza: Expressão Gráfica, 2016. 4 v.

MARTINS, Vicente. Notícia histórico-chorographica da Comarca de Granja. Revista do Instituto do Ceará, Fortaleza, t. 29, p. 3-57, 1915.

MENZ, Maximiliano. A integração do guarani missioneiro na sociedade sul-rio-grandense. 2001. Dissertação (Mestrado em História) - Universidade do Vale do Rio dos Sinos, São Leopoldo, 2001.

MORAES, Antonio Carlos Robert. Bases da formação territorial do Brasil: o território colonial brasileiro no "longo" século XVI. São Paulo: Hucitec, 2000.

MOREIRA, Rafael. A circulação das formas: artes portáteis, arquitectura e urbanismo. In: BETHENCOURT, Francisco; CHAUDHURI, Kirti Narayan (orgs.). História da expansão portuguesa: do Índico ao Atlântico (1570-1697). Lisboa: Círculo de Leitores, 1998. v. 2, p. 532-570.

MOREIRA, Rafael. Conhecer Portugal. In: BUENO, Beatriz Piccolotto Siqueira. Desenho e desígnio: o Brasil dos engenheiros militares (1500-1822). São Paulo: Edusp, 2011. p. 13-21.

NOBRE, Geraldo da Silva. As oficinas de carnes do Ceará: uma solução local para uma pecuária em crise. Fortaleza: Grecel, 1977. 
NOBRE, Geraldo da Silva. João da Silva Feijó: um naturalista no Ceará. Fortaleza: Grecel, 1978.

NOGUEIRA, Gabriel Parente. Viver à lei da nobreza: elites locais e o processo de nobilitação na Capitania do Siará Grande (1748-1804). Curitiba: Appris, 2017.

NOGUEIRA, Paulino. O naturalista João da Silva Feijó. Revista do Instituto do Ceará, Fortaleza, t. 2 , p. $247-276,1888$.

OLIVEIRA, André Frota de. Quadro da História de Granja no Século XIX. Fortaleza: Expressão Gráfica, 1996.

OLIVEIRA, Mário Mendonça de. Proêmio. In: VELlOZO, Diogo da Sylveyra. Arquitetura militar ou fortificação moderna. Salvador: Edufba, 2005. p. 9-20.

OLIVEIRA, Myriam Ribeiro. O Rococó religioso no Brasil e seus antecedentes europeus. São Paulo: Cosac \& Naify, 2003.

PAIVA, Melquíades Pinto. Os Naturalistas e o Ceará: I - João da Silva Feijó (1760-1824). Revista do Instituto do Ceará, Fortaleza, t. 105, p. 21-44, 1991.

PEREIRA, Magnus Roberto de Mello; SANTOS, Rosângela Maria Ferreira dos. João da Silva Feijó: um homem de ciências no Antigo Regime português. Curitiba: Editora UFPR, 2012.

PIMENTEL, Luís Serrão. Méthodo lusitânico de desenhar as fortificações das praças regulares e irregulares. Lisboa: Direção do Serviço de Fortificações e Obras do Exército, 1993. Fac-símile.

PINHEIRO, Adson Rodrigo Silva. Novos ares, nova vida: mobilidade, casamento e família nos sertões do Siará Grande (1759-1766). 2016. 234f. - Dissertação (Mestrado) - Universidade Federal do Ceará, Programa de Pós-Graduação em História, Fortaleza, Ceará, 2016.

PORDEUS, Ismael. Antônio Dias Ferreira e a Matriz de Quixeramobim: subsídios históricos para as festividades do centenário da Paróquia. Revista do Instituto do Ceará, Fortaleza, t. 69, p. 189-213, 1955.

PORDEUS, Ismael. Escritos sobre Antônio Conselheiro e a Matriz de Quixeramobim. Fortaleza: Museu do Ceará, 2011.

PUTONI, Pedro. A Guerra dos Bárbaros: povos indígenas e a colonização do sertão nordestino do Brasil, 1650-1720. São Paulo: Hucitec, 2002.

REIS FILHO, Nestor Goulart. Contribuição ao estudo da evolução urbana do Brasil (15001720). São Paulo: Pioneira, 1968. 
RIBEIRO, Dulcyene Maria. A formação dos engenheiros militares: Azevedo Fortes, matemática e ensino da engenharia militar no século XVIII em Portugal e no Brasil. 2009. Tese (Doutorado em Ensino de Ciências e Matemática) - Universidade de São Paulo, São Paulo, 2009.

ROLIM, Leonardo Cândido. A rosa dos ventos dos sertões do Norte: dinâmicas do território e exploração colonial (c. 1660 - c. 1810). 2019. Tese (Doutorado em História Econômica) Universidade de São Paulo, São Paulo, 2019.

ROSSA, Walter. A engenharia militar e a cidade portuguesa: pretexto para abordagem e evoluções recentes da historiografia do urbanismo. In: ROSSA, Walter. A urbe o traço: uma década de estudos sobre o urbanismo português. Coimbra: Almedina, 2002. p. 163-172.

RUSSELL-WOOD, Anthony John R. O Império Português: 1415-1808: o mundo em movimento. Lisboa: Clube do Autor, 2017.

RUSSELL-WOOD, Anthony John R. Padrões de colonização no Império Português: 1400-1800. In: BETHENCOURT, Francisco; CURTO, Diogo Ramada (orgs.). A expansão marítima portuguesa: 1400-1800. Lisboa: Edições 70, 2020. p. 171-206.

SANTOS, Benedicto. Memórias da Matriz de Aracaty. Revista do Instituto do Ceará, Fortaleza, t. 32, p. 308-322, 1918.

SERRÃO, Joel. Conspecto histórico da emigração portuguesa. Análise Social, Lisboa, v. 8, n. 32, p. 597-617, 1970.

SILVA, Luiz Geraldo. "Esperança de liberdade": interpretações populares da abolição ilustrada (1773-1774). Revista de História, São Paulo, n. 144, p. 107-149, 2001.

SILVA, Rafael Ricarte da. A Capitania do Siará Grande nas dinâmicas do Império Português: política sesmarial, guerra justa e formação de uma elite conquistadora (1679-1720). 2016. Tese (Doutorado em História Social) - Universidade Federal do Ceará, Fortaleza, 2016.

SMITH, Robert. A talha em Portugal. Lisboa: Livros Horizonte, 1962.

STUDART, Guilherme. Notas para a história do Ceará: segunda metade do século XVIII. Lisboa: Typografia do Recreio, 1892.

STUDART, Guilherme. Datas e factos para a bistória do Ceará. Fortaleza: Typographia Studart, 1896.

STUDART, Barão de. Geographia do Ceará. Revista do Instituto do Ceará, Fortaleza, t. 37, p. 160-384, Fortaleza, 1923.

STUDART FILHO, Carlos. As fortificações do Ceará. Revista do Instituto do Ceará, Fortaleza, t. 44, p. 48-94, 1930. 
STUDART FILHO, Carlos. Vias de comunicação do Ceará colonial. Revista do Instituto do Ceará, Fortaleza, t. 51, p. 15-47, 1937.

VALLADARES, Clarival do Prado. Nordeste histórico e monumental. Salvador: Odebrecht, 1983.

VELLOZO, Diogo da Sylveyra. Arquitetura militar ou fortificação moderna. Salvador: Edufba, 2005.

VITERBO, Sousa. Expedições científico-militares enviadas ao Brasil. Lisboa: Edições Panorama, 1962. v. 1.

VITERBO, Sousa. Expedições científico-militares enviadas ao Brasil. Lisboa: Edições Panorama, 1964. v. 2.

VITERBO, Sousa. Dicionário histórico e documental dos arquitectos, engenheiros e construtores portugueses. Lisboa: Imprensa Nacional, 1988. $3 \mathrm{v}$.

Artigo apresentado em: 1/7/2020. Aprovado em: 8/12/2020.

\section{(cc) BY}

All the contents of this journal, except where otherwise noted, is licensed under a Creative Commons Attribution License 


\section{ERRATA}

\section{Anais do Museu Paulista: História e Cultura Material}

https://doi.org/10.1590/1982-02672021v29dlelbe

No artigo "Mobilidade e interconexões oceânicas: o engenheiro militar e o artífice entre a Capitania do Ceará e o reino de Portugal", com número DOl <https: / / doi.org/ 10.1590/1982-0267202 1v29d le16>, publicado no periódico Anais do Museu Paulista: História e Cultura Material, vol. 29, 2021 , p. 1-95. d le 16 :

\section{Na página 3}

\section{Onde se lia:}

\section{NOTA}

"3. Dentre os estudos, destacamos Matrizes e capelas do Ceará: circularidade e conexões atlânticas: arquitetura e artífices entre os sertões do Norte e Portugal (1700-1820), de José Ramiro Teles Beserra (2018); Um sertão entre tantos outros: fazendas de gado nas Ribeiras do Norte, de Nathália Diniz (2013); Ecos de um suposto silêncio: paisagem e urbanização dos "certoens" do Norte, c. 1666-1820, de Damião Esdras Araujo Arraes (2017); A rosa dos ventos dos sertões do Norte: dinâmicas do território e exploração colonial (c. 1660 - c. 1810), de Leonardo Cândido Rolim (2019); A Capitania do Siará Grande nas dinâmicas do Império Português: política sesmarial, guerra justa e formação de uma elite conquistadora (1679-1720), de Rafael Ricarte da Silva (2016); e Viver à lei da nobreza: elites locais e o processo de nobilitação na Capitania do Siará Grande (1748-1804), de Gabriel Parente Nogueira (2017)."

\section{Leia-se:}

\section{NOTA}

"3. Dentre os estudos, destacamos Matrizes e capelas do Ceará: circularidade e conexões atlânticas: arquitetura e artífices entre os sertões do Norte e Portugal 
(1700-1820), de José Ramiro Teles Beserra (2018); Um sertão entre tantos outros: fazendas de gado nas Ribeiras do Norte, de Nathália Diniz (2013); Ecos de um suposto silêncio: paisagem e urbanização dos "certoens" do Norte, c. 1666-1820, de Damião Esdras Araujo Arraes (2017); A rosa dos ventos dos sertões do Norte: dinâmicas do território e exploração colonial (c. 1660 - c. 1810), de Leonardo Cândido Rolim (2019); A Capitania do Siará Grande nas dinâmicas do Império Português: política sesmarial, guerra justa e formação de uma elite conquistadora (1679-1720), de Rafael Ricarte da Silva (2016); Viver à lei da nobreza: elites locais e o processo de nobilitação na Capitania do Siará Grande (1748-1804), de Gabriel Parente Nogueira (2017); e Novos ares, nova vida: mobilidade, casamento e família nos sertões do Siará Grande (1759-1766), de Adson Rodrigo Silva Pinheiro (2016)."

\section{Na página 46}

\section{Onde se lia:}

"À parte o anonimato das obras e o desconhecimento da proveniência exata dos artífices e das referências decorativas e arquitetônicas, pesquisas recentes com fontes pouco usuais e até então inéditas - arquivos paroquiais e documentação indiciária - têm revelado o nome e a trajetória de alguns desses importantes agentes da cultura artística dos sertões do Norte."

\section{Leia-se:}

À parte o anonimato das obras e o desconhecimento da proveniência exata dos artífices e das referências decorativas e arquitetônicas, pesquisas recentes com fontes pouco usuais e até então inéditas - arquivos paroquiais e documentação indiciária - têm revelado o nome e a trajetória de alguns desses importantes agentes da cultura artística dos sertões do Norte. ${ }^{165 "}$

\section{Na página 46}

\section{Onde se lia:}


"Uma rara e das mais antigas referências a noticiar e valorar obras de talha oriundas do período colonial no Ceará é a nota de João José Rescala - representante do Serviço do Patrimônio Histórico e Artístico Nacional (Sphan) ${ }^{165}$ que percorreu os sertões cearenses nos primeiros anos da década de 1940 - sobre o retábulo da lgreja Matriz de Nossa Senhora da Expectação de Icó."

\section{Leia-se:}

"Uma rara e das mais antigas referências a noticiar e valorar obras de talha oriundas do período colonial no Ceará é a nota de João José Rescala - representante do Serviço do Patrimônio Histórico e Artístico Nacional (Sphan) que percorreu os sertões cearenses nos primeiros anos da década de 1940 - sobre o retábulo da Igreja Matriz de Nossa Senhora da Expectação de Icó."

\section{Na página 46}

\section{Onde se lia:}

\section{NOTA}

"165. Sphan foi a primeira denominação do atual Instituto do Patrimônio Histórico e Artístico Nacional (Iphan), que vigorou de 1937 a 1946, período em que se deu a missão de Rescala ao Ceará."

\section{Leia-se:}

\section{NOTA}

"165. Destaca-se o trabalho de Pinheiro (2016) que, investigando Processos Inquisitoriais presentes no Arquivo da Torre do Tombo, trouxe à luz a trajetória de vida e profissional dos artífices portugueses Antônio Correia de Araújo Portugal e Antônio Mendes da Cunha, de quem aqui trataremos. $\bigcirc$ referido trabalho forneceu importante aporte metodológico na estruturação de nossa análise, tanto no que diz respeito ao tratamento das referidas fontes primárias sob um viés historiográfico cronológico da mobilidade destes personagens, como ao propor a espacialização, em mapas, do seu trajeto e circularidade." 


\title{
Na página 47
}

Onde se lia:

\author{
NOTA \\ "166. Rescala (1941)."
}

Leia-se:

\section{NOTA}

"166. Sphan foi a primeira denominação do atual Instituto do Patrimônio Histórico e Artístico Nacional (IPHAN), que vigorou de 1937 a 1946, período em que se deu a missão de Rescala ao Ceará."

\section{Na página 93}

Onde se lia:

PIMENTEL, Luís Serrão. Méthodo lusitânico de desenhar as fortificações das praças regulares e irregulares. Lisboa: Direção do Serviço de Fortificações e Obras do Exército, 1993. Fac-símile.

PORDEUS, Ismael. Antônio Dias Ferreira e a Matriz de Quixeramobim: subsídios históricos para as festividades do centenário da Paróquia. Revista do Instituto do Ceará, Fortaleza, t. 69, p. 189-213, 1955.

\section{Leia-se:}

PIMENTEL, Luís Serrão. Méthodo lusitânico de desenhar as fortificações das praças regulares e irregulares. Lisboa: Direção do Serviço de Fortificações e Obras do Exército, 1993. Fac-símile.

PINHEIRO, Adson Rodrigo Silva. Novos ares, nova vida: mobilidade, casamento e família nos sertões do Siará Grande (1759-1766). 2016. 234f. - Dissertação (Mestrado) - Universidade Federal do Ceará, Programa de Pós-Graduação em História, Fortaleza, Ceará, 2016. 
PORDEUS, Ismael. Antônio Dias Ferreira e a Matriz de Quixeramobim: subsídios históricos para as festividades do centenário da Paróquia. Revista do Instituto do Ceará, Fortaleza, t. 69, p. 189-213, 1955.

\section{(c) BY}

All the contents of this journal, except where otherwise noted, is licensed under a Creative Commons Attribution License 